\title{
THE HYDROGEN BOMB TESTS IN PERSPECTIVE: LAWFUL MEASURES FOR SECURITY
}

\author{
MYRES S. MCDOUGAL† and NORBERT A. SEHLEI††
}

\begin{abstract}
"Unless a trustworthy and universal agreement upon disarmamemt, conventional and muclear alike, can be reached and an effective system of inspection is established and is actually zorking, there is only onc sane policy for the free world in the next few years. That is zwat we call defense through deterrents. This we have already adopted and proclaimed."
\end{abstract}

-Sir Winston Churchill 1

\section{The Legal Policy Issue}

ON January 31, 1950, President Truman reluctantly ordered the Atomic Energy Commission to proceed with development of the hydrogen bomb." Political leaders of every shade of belief supported the decision, as did the American public, most statesmen of the western world, the Vatican, and others. $^{3}$ The decision was taken, and was generally approved, becatise the Soviet Union had refused to agree to a workable scheme of international control of armaments, and had thus given the United States no choice but to engage in an arms race of unprecedented magnitude and intensity. The security of the United States and of the whole free world depended, it was almost universally agreed, upon victory or at least parity in this race. Subsequently it became known that the Soviet Union had begun its own thermonuclear research in 1945, and was ahead of the west in the technological . struggle at the time of President Truman's decision. ${ }^{4}$

†William K. Townsend Professor of Law, Yale Law School.

†TMember of the Editorial Board, Yale Law Journal.

The authors make acknowledgment to William T. Burke, Graduate Fellow in the Yale Law School, for helpful suggestions and to the Wenner-Gren Foundation for Anthropological Research for grants in aid of some of the research upon which the article is based.

[Editor's note: Since this article constitutes in part a reply to the immediately preceding article, it is appropriate to note that it was not possible to make it available to Dr. Margolis before publication.]

1. N.Y. Times, March 2, 1955, p. 8, col. 2.

2. N.Y. Times, Feb. 1, 1950, p. 1, col. 8.

3. For expressions of opinion on the issue, see, e.g., N.Y. Times, Jan. 18, 1950, p. 30, col. 3; id., Jan. 19, 1950, p. 12, col. 4 (Dr. Compton); id., Jan. 28, 1950, p. 6, cols. 2, 3 (Dr. Urey) ; id., Jan. 29, 1950, p. 1, col. 4, \$4, p. 8, col. 2 (Sen. Connally and others); id., Jan. 31, 1950, p. 1, col. 8 (Sen. Tydings and Mr. Lilienthal) ; id., Feb. 1, 1950, p. 4, col. 2 (Mr. Baruch); id., Feb. 2, 1950, p. 7, cols. 3, 4 (Sen. Vandenberg); id., Feb. 3, 1950 , p. 3, cols. 1, 2 (Osservatore Romano and Mr. McCloy). Congress unanimoussly approved the funds requested for the program. Id., Sept. 1, 1950, p. 28, col. 2.

4. Statement by Commissioner Strauss reported in N.Y. Times, April 1, 1954, p. 20, col. 1. 
The first thermonuclear bomb tests conducted by the United States, in March and April of 1954 in the Pacific Proving Grounds, demonstrated the enormous destructive power of the new weapon, and caused great concern the world over. Through a series of miscalculations, a number of Marshallese, Japanese, and Americans were injured by the test of March 1st, and the test series as a whole in some measure disrupted the activities of a segment of the Japanese fishing industry. As might have been foreseen, the Soviet Lnion denounced the tests, characteristically couching its invective in the vocabulary of law, and appealing to the abhorrence, shared by all peoples of the world, of the destructive power of the weapon." The United States promptly took all possible measures to repair the damage done, and expressed its extreme regret that the mishaps had occurred. ${ }^{\circ}$ After full compensation had been paid or promised to the victims of the test accidents, ${ }^{7}$ and the Trusteeship Council had accepted United States assurances that similar accidents could and would be prevented in the future, ${ }^{8}$ the spurious legalisms of the Soviet Union might appropriately have been dismissed with a minimum of consideration. Unfortunately, however, certain neutral statesmen and impartial observers also have questioned the legality of these tests, appealing both to certain customary prescriptions of the international law of the sea and to certain provisions of the United Nations Charter and of the Trusteeship Agreement, under which the United States holds the Pacific Islands.

In accord with the overwhelming demands of all peoples who value not merely human dignity but even human survival, the United States is continuing to make every practicable effort to achieve world disarmament and to outlaw nuclear weapons. ${ }^{10}$ In the contemporary context of failure to achieve

5. See, e.g., U.N. Trustership Couscir. Ofr. Rec., 14th Sess., 561st meeting 244-48 (1954) ; Standing Committee on Petitions, U.N. Trusteeship Council, Summary Rccord (Doc. No. T/C.2/SR.198) (1954).

6. Standing Committee on Petitions, U.N. Trusteeship Council, sith Reforl 4 (Doc. No. T/L.510) (1954). See also N.Y. Herald Tribune, April 10, 1954, p. 2, col. 6.

7. A $\$ 2,000,000$ payment to Japar, "without reference to the question of legal liability" was agreed upon Jan. 4, 1955. N.Y. Times, Jan. 5, 1955, p. 6, col. 1. Settlement of all Marshallese claims was reported in immediate prospect. Conmunieation from Deputy High Commissioner, Trust Territory of the Pacific Islands, to the Iale Lore Journal, Feb. 24, 1955, on file in Yale Law Library.

S. U.N. Trustership Council Off. Rec., 14th Sess., Solst meeting 248 (195t), adopting by 9 votes to 3 the joint draft resolution, U.N. Doc. No. T/L 504 (1954), submitted by Belgium, France, and the United Kingdom.

9. For assertions that the tests violate the law of the sea, and collection of citations, see Margolis, The Hydragen Bomb Experiments and International Lai, of Y.ALE L.J. 629, 629 n.3, 635, 640 (1955) (hereinafter cited as Mlargolis); Laurents, Exferincm in Amitilation, 5 Contexp. Issues 214 (1954) ; N.Y. Times, March 26, 1954, p. 5, col. 5 (Japanese Seamen's Union). See also the remarks of the Earl Jowett in 186 H.L. Deb. (5th Ser.) 808-09 (1954). For assertions that the tests contravene the Charter and Trustezship Agreement, see .liargolis, p. 645; remarks of the Soviet and Indian representatives in the U.N. Trusteeship Council and its Committee on Petitions, cited supra note 5.

10. For an account of U.S. efforts from 1945 to 1950 to attain internatiunal control of atomic weapons, see Jont Connartee ox Atomic Exescy, Tue Hronoge: Bond 
effective international control of armaments, the United States considers, however, that it has no alternative but to keep itself armed for self-clefense as best it can. ${ }^{11}$ Fortunately, almost all proponents of the free world-whatever their idiosyncratic views about either strategy or tactics-still agree in this determination, and recognize that to forego the testing and development of the new weapons would amount only to unilateral disarmament, with attendant invitation to destruction. ${ }^{12}$

The basic issue in legal policy thus joined, in this conflict between the claim of the United States to conduct the hydrogen bomb tests and the demands of others for their discontinuance, is, therefore, whether the United States and its associates are authorized by relevant world prescription to continue measures which they deem essential to their clefense or whether such measures must be condemned as unlawful, either through derivations from the customary international law of the sea or by application of special commitments undertaken in the United Nations Charter and the Trusteeship Agreement.

\section{The FActs}

The Trust Territory of the Pacific Islands is composed of 98 island groups (2000 islands) with a total dry land area of 846 square miles, spread over some 3,000,000 square miles of the North Pacific Ocean. ${ }^{13}$ The United States governs the Territory as a strategic trusteeship territory under an agreement with the United Nations which entered into force July 18, 1947.14

Testing of atomic weapons in the Pacific began with the test series conducted at Bikini Atoll in July 1946, ${ }^{15}$ before the Pacific Islands became a

and International Control: Technical and Background Information, 81st Cong., 2d Sess. 13-20 (1950). For analysis of recent developments see Cavers, The Arms Stalemate Ends, 11 Bull. Atom. Scientists 9 (1955).

11. See State of the Union messages of Presidents Truman and Eisenhower. N.Y. Times, Jan. 8, 1953, p. 10, col. 1; id., Jan. 7, 1955, p. 10, cols. 1, 2.

12. See, e.g., Davis, Two Minutes till Midnight c.2 (1955); Finletter, Power and Policy 376-402 (1954); Slessor, Strategy for the West 106-07 (1954); Morgenthau, The Political and Military Strategy of the United States, 10 Bull. Atom. ScienTISTs 323, 325 (1954); Woodward, "By Man Came Death," 11 id. 19 (1955); Marscille, Negotiation from Strength, 11 id. 13 (1955); National Planning Association, American Policy in the Newe Phase of the Cold War, 11 id. 97 (1955); Williams, The Griat Debate: 1954, 80 U.S. Naval Inst. ProceEdras 247 (1954); Bryant, Co-existence-But Not Surrender, N.Y. Times Mag., Feb. 6, 1955, p. 15; Spaak, The Atom Bomb and NATO, 33 Foreign Affairs 353 (1955). See also Prime Minister Churchill's address on defense and the hydrogen bomb, N.Y. Times, Mar. 2, 1955, p. 8, col. 1; British Government Annual Statement on Defense, excerpted in id., Feb. 18, 1955, p. 1, col. 2; remarks of Labor Party leader Clement Attlee reported in Time, March 14, 1955, p. 33, col. 3.

13. Hearings before the Senate Committee on Foreign Relations on S.J. Res. 143, 80th Cong., 1st Sess. 2 (1947); U.S. Navy Dep't, Trust Territory of THe Pacific IsLANDS 1, 77 (1948) (apparently giving total area of inhabited islands only).

14. 61 Stat. 3301, T.I.A.S. No. 1665, 8 U.N. Trenty SER. 189 (hereinafter cited as TRUSTEESHIP AGREEMENT).

15. N.Y. Times, July 1, 1946, p. 1, col. 8; id., July 25, 1946, p. 1, col. 8. 


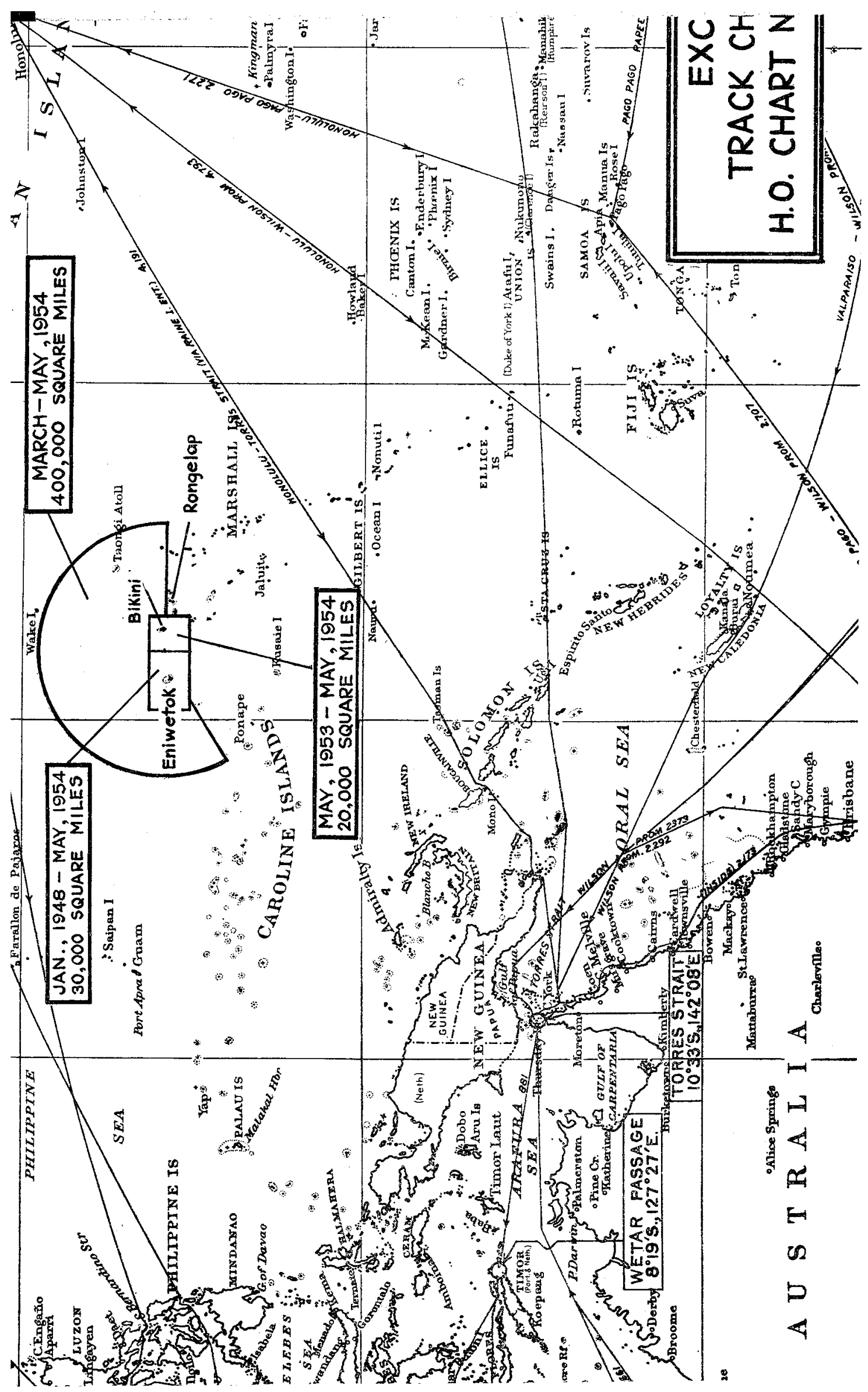




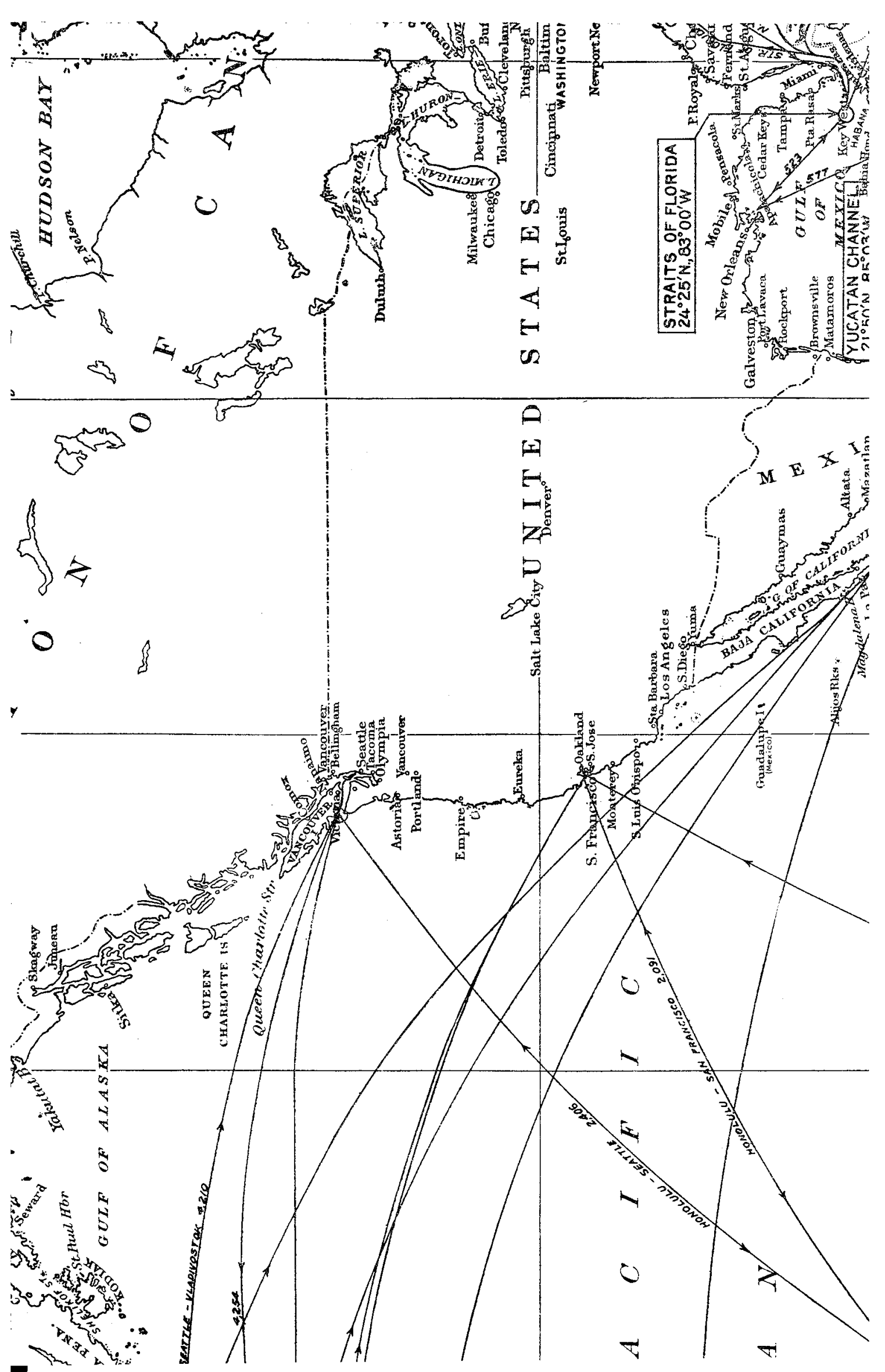




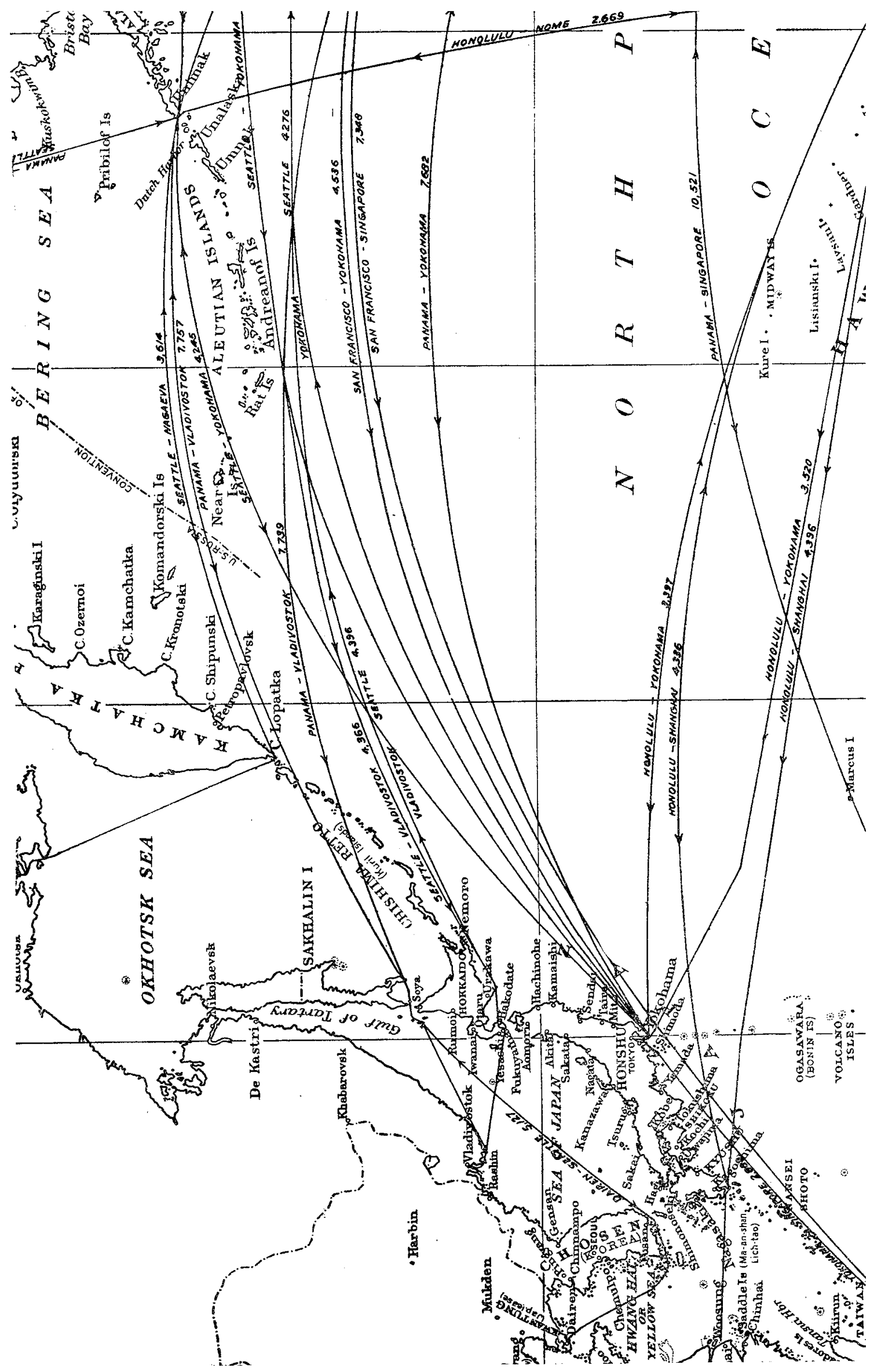


Trust Territory. On July 23, 1947, the AEC announced establishment of the Pacific Proving Grounds, ${ }^{16}$ and in December chose Eniwetok Atoll, near Bikini in the Marshall Islands, as a site for subsequent testing activities. ${ }^{17}$ The U.N. Security Council was advised by the United States that the atoll and its territorial waters had been closed for security reasons, in accordance with Article 13 of the Trusteeship Agreement, in order to enable the AEC to conduct atomic tests. ${ }^{18}$

Because of the anticipated danger to ships approaching too near to Bikini while tests were in progress in 1946, mariners were advised through normal channels, during the months May through August, that the waters in an area of approximately 180,000 square miles surrounding the atoll should be avoided. ${ }^{19}$ With the removal of testing operations to Eniwetok, mariners were warned, in January 1947, and thereafter, that a zone of approximately 30,000 square miles would be dangerous to all ships, aircraft, and personnel, and at times of actual danger the area was patrolled to ensure that no ships or aircraft entered inadvertently. ${ }^{20}$ In May 1953, the warning area was expanded to include Bikini and its surrounding waters, and from that date until the most recent test series, the warning area included approximately 50,000 square miles. ${ }^{21}$ In March 1954, when it had become apparent that the warning area then in effect was inadequate, it was extended to include a total area of approximately 400,000 square miles. ${ }^{22}$ On NIay 21, 1954, 57 days later,

16. N.Y. Times, July 24,1947 , p. 1, col. 2.

17. N.Y. Times, Dec. 2, 1947, p. 1, col. 6.

18. Letter from the Representatize of the U.S. concerning the conducling of experiments relating to nuclear fission on Eniactok Atoll in the Trust Territury of the Pacific Islands, U.N. Doc. No. S/613 (1947).

19. U.S. Navy Hydrographic Office, Notice to Mariners No. 19, para. 2915 (May 11,1946 ), repeated in $i d$. Nos. $20-31$ of 1946 , canceled, id. No. 32, para 4647 (August 10,1946 ). A warning zone embracing some 2400 square miles of open sea southwest of Eniwetok was in effect for more than a year. Id. No. 52, para. 6627 (Dec. 29, 1945); id. No. 1, para. 92 (Jan. 4, 1947).

20. U.S. Navy Hydrographic Office, Notice to Mariners, pt. 2, No. 3, para. 329 (Jan. 17,1948 ), reprinted in id. Nos. 4, 6, 8, 9, 14, 52 of 1948, 40 of 1952. For description of patrolling practices, see N.Y. Times, April 1, 1954, p. 20, col. 2. For pictorial presentation of the dimensions of this and subsequent warning zones, see U.S. Navy Hydrographic Office, Track Chart of the World (No. 1262, 27th ed. 1943), excerpt reproduced opposite p. 650 supra.

21. U.S. Navy Hydrographic Office, Notice to Mariners, pt. 2, No. 21, para. 2716 (May 23, 1953).

22. Id., No. 14, para. 1685 (April 3, 1954). The warning was issued by radio on March 26, 1954.

It should be emphasized that the actual blast effects of the bomb did not by any means extend over this area, or even the smaller areas previously in effect. The fallout of radioactive materials from a thermonuclear explosion, however, may contaminate an area up to forty miles in width, extending downwind approximately 220 statute miles. See generally Statement by Lewis L. Strauss, Chairman, USAEC Press Release, Feb. 15, 1955, pp. 1-3; N.Y. Times, April 1, 1954, p. 16, cols. 4, 6.

The March-1 May warning area extended 450 nautical miles frum Bikini in a seetor extending from east $\left(095^{\circ}\right)$ to west by southwest $\left(240^{\circ}\right)$. This larger warning area was 
all warning zones were canceled. ${ }^{23}$ Bikini and Eniwetok, and their territorial waters, remained closed areas. ${ }^{24}$

The magnitude of the test explosion of March 1, 1954, was underestimated by half, and the error in advance calculations was compounded by erroneous wind predictions. ${ }^{25}$ This series of miscalculations resulted in minor injuries to twenty-eight Americans and approximately eighty-two Marshallese on islands outside the warning zone. ${ }^{26}$ Injuries which eventually became serious were suffered by the twenty-seven man crew of the Japanese fishing craft Fukuryu Maru, which apparently lay some fourteen miles clear of the warning zone at the time of the explosion, and did not arrive in Japan until some weeks later. ${ }^{27}$

The extent to which fish contaminated by radioactive fallout were found outside the immediate vicinity of the tests is not clear. ${ }^{28}$ In any event, Japanese authorities inaugurated a system of monitoring for radioactivity the catches of ships reaching port from a wide area in the North Pacific, and condemned a considerable quantity of fish. ${ }^{29}$ None of the rumors of injury from contaminated fish have been substantiated, and it seems certain that none ever occurred.

apparently established to avoid danger from movement of fallout materials with occan currents in the area, which flow west and northwest. For current data see U.S. Dep't of Interior, The Japanese Tuna Fisheries 8-9 (Fishery Leaflet No. 297, 1948). The $\mathrm{AEC}$ has stated that radioactivity borne on ocean currents disperses to a point at which it becomes "undetectable" within 500 miles or less. N.Y. Times. April 1, p. 20, col. 6.

23. U.S. Navy Hydrographic Office, Notice to Mariners, pt. 2, No. 23, para. 2932 (June 5, 1954) ; N.Y. Times, May 22, 1954, p. 6, col. 5.

24. U.S. Navy Hydrographic Office, Notice to Mariners, pt. 2, No. 23, para. 2932 (June 5, 1954).

25. Admiral Strauss' report in N.Y. Times, April 1, 1954, p. 20, col. 1.

26. Ibid.; Communication from Deputy High Commissioner, Trust Territory of the Pacific Islands, to the Yale Law Journal, Feb. 24, 1955, on file in Yale Law Library. 236 Marshallese, a figure often given as the number injured, were evacuated from Rongelap and Utirik Atolls, but the 154 Utirikese were unharmed. The Rongelapesc were treated for depilation and superficial burns at Kwajalein, then resettled on Majuro Atoll in June. All physical effects had disappeared by July, and no permanent after-effects are expected. The Utirikese were returned to their homes in May, as soon as the AEC could determine that the atoll was not radioactive. Ibid. For poptuation statistics, sce Standing Committee on Petitions, U.N. Trusteeship Council, sith Report 5 (Doc. T/L 510) (1954).

27. Arnold, Effects of the Recent Bomb Tests on Human Bcings, 10 BuLL. Arou. Scientists 347 (1954). Some months later, one of the seamen died. Armold expresses the opinion that the survival of the others, after going so long without treatment after so heavy and prolonged exposure to radiation, is "due to remarkable medical efforts." Ibid. Arnold's account suggests that the eventual seriousness of the seamen's injuries was attributable to the fact that they continued to be exposed to radiation for sonic two weeks on the return trip to Japan, and were not all hospitalized until four weeks after their initial exposure. Ibid.

28. For analysis of conflicting reports, see note 235 infra. We here assume, for purposes of argument, that some radioactive fish were caught outside the warning zone, and that safety would require monitoring deep-sea catches from a wide area in the North Pacific Ocean for radioactivity after each test.

29. Arnold, supra note 27 , at 347 . 
The United States meanwhile took swift action to mitigate the effects of the test mishaps. Injured Marshallese were given immediate medical care at naval facilities on nearby Kwajalein Atoll; expert medical personnel were rushed to their assistance, and to that of the injured Japanese fishermen as soon as their plight became known; and prompt assurances were given that all financial loss would be made good. ${ }^{30}$ Two million dollars has been paid to Japan for damages resulting from the tests, including both personal injuries suffered by the crew of the Fukuryu Maru and damage to the Japanese fishing industry. ${ }^{31}$ Settlement of all Marshallese claims is in immediate prospect. $^{32}$

The United States has stated that if it finds it necessary to conduct further tests, it will take all necessary precautions to avoid further injury. ${ }^{33}$ Presumably among the measures taken would be the establishment of a varning area comparable in size to that in effect during April and May 1954, and temporary evacuation of the atolls nearest the test area. In this connection, it should be noted that such a warning area would extend some hundreds of miles beyond the point at which injuries were sustained by the crew of the Fukuryu Maru, ${ }^{34}$ and that evacuation of every atoll affected by the tests of 1954 would temporarily displace 236 people from a total land area of 4.01 square miles. ${ }^{35}$

30. Standing Committee on Petitions, U.N. Trusteeship Council, s7lh Report 5 (Doc. No. T/L. 510) (1954) ; Mianchester Guardian, March 24, 1954, p. 2, col. 1; N.Y. Times, March 25, 1954, p. 18, col. 7. See note 7 supra.

31. N.Y. Times, Jan. 5, 1955, p. 6, col. 1.

32. Communication from Deputy High Commissioner, Trust Territory, suprs note 26.

33. See, e.g., Standing Committee on Petitions, U.N. Trustceship Council, Stummary Record 3 (Doc No. T/C.2/SR.197) (1954); U.N. Trusteeship Couscil Off. ReC, 14th Sess., 561st meeting 245 (1954).

34. See notes 22-27 supra and accompanying text.

35. For land and population data, see U.S. Dep't of Interror, 1952 ReFont on the Adarinistration of the Trust Territory of the Pactfic Islatids 68 (1953).

Evacuation of an area 260 statute miles in radius surrounding Eniwetok Atoll would affect only Ujelang Atoll, with a population of 163 and a land area of 67 square miles. Ibid. The possibility that Ujelang, some 130 miles away from Eniwetok, would be affected by the fallout of a thermonuclear explosion ( 40 miles in width, sce Statement by Lewis L. Strauss, Chairman, USAEC Press Release, Feb. 15, 1955, p. 2), would amount to less than one chance in twenty, even assuming total failure of wind predictions. The inhabitants could, therefore, very probably be returned to their homes with perfect safety immediately after completion of a test series.

Since its inception in 1946, at Bikini, the nuclear testing program has necessitated the relocation, temporary or relatively permanent, of a total of 510 Mfarshallese, from islands with a total area of nine square miles. See note 26 supra: U.S. Nary Dep'r, Trust Territory of the Pactifc Islands 77 (1948). The land area of Bikini is 2.87 square miles, 69 World AlManac 519 (1954), and that of Eniwetok 2.26 square miles. N.Y. Times, Dec. 2, 1947, p. 24, col. 5. All land taken has been replaced from the public domain, and full compensation has been paid for all financial loss. U.S. DEP'T of I:TERTOR, 1952 REPORT, op. cit. supra, at 35; Standing Committee on Petitions, supra note 33 , at 6-7. 


\section{The Attack upon Legality}

Those who attack the legality of the Pacific tests ordinarily begin by implying that any use of atomic and thermonuclear weapons would be unlawful and that this conclusion has some relevance to the legality of the tests. ${ }^{36}$ Their principal attack is, however, cast in terms of so-called "traditional and universally accepted rules" said to be found in the international law of the sea, ${ }^{37}$ and an attempted "inescapable" interpretation of the U.N. Charter and the Trusteeship Agreement for the Former Japanese Mandated Islands. ${ }^{38}$ The most comprehensive and detailed elaboration of this attack appears in the immediately preceding article by Dr. Emanuel Margolis. ${ }^{30}$

"Freedom of navigation," "freedom of fisheries," "freedom to lay submarine cables," and "freedom of aerial movement," Dr. Margolis argues, are "corollaries" of the "absolute rule" of "freedom of the seas." 40 Although there are some "general police powers" which may be exercised on the high seas "in time of peace," and some "special police powers" which may be acquired by treaty, the bomb tests and the warning areas they make necessary fall within neither class. ${ }^{41}$ They are, therefore, forbidden by the "clear rule of law" that "no state can exercise sovereignty over the high seas in time of peace." 4 " It is further argued that the tests' injurious effects upon fishing, outside the zone of immediate danger, violate some ill-defined international prescription against pollution, or at least do not measure up to "justice and equity," and that the tests must therefore be stopped. ${ }^{43}$

Finally, it is asserted as an "inescapable" conclusion that testing of nuclear weapons by the United States in the Pacific Proving Grounds is "at variance" with the "unqualified imperatives" of Article 73 of the U.N. Charter and Article 6 of the Trusteeship Agreement. ${ }^{44}$ By selective reading from that article of the Charter, it is noted that member states there recognize the principle that the interests of the inhabitants of non-self-governing territories "are paramount," and accept as a "sacred trust" the obligation to promote the "well-being" of the inhabitants and to this end to ensure their protection against "abuses." ${ }^{45}$ By similar exegesis upon the Trusteeship Agreement, it is added that the Administering Authority undertook to promote the economic development of the inhabitants by "the development of fisheries," to protect the inhabitants against "the loss of their lands and resources," and

36. Margolis, pp. 629 n.2, 639 n.59.

37. Id. at 636 .

38. Id. at 643-45.

39. Margolis, The Hydrogen Bomb Experiments and International Law, 64 YaL: L.J. 629 (1955).

40. Id. at 630,634 .

41. Id. at 634-36.

42. $I d$. at 635 .

43. Id. at 641-43.

44. Id. at 643-45.

45. Ibid. 
"to protect the health of the inhabitants." 40 It is argued, further, that these provisions are not, at least not within the same section, "diluted" by the phrase: "subject to the requirements of security." 1 it is then stated as a fact that injury to persons and property in connection with tests is "bound to occur," and that the tests therefore violate the Agreement." B But even if danger of injury could be eliminated the tests would still be illegal, it is said, because the necessary safety measures would violate the agreement in that they would involve "removing [the inhabitants] from their land," and "depriving them of fishing grounds for months at a time." It makes no difference to this conclusion that the Agreement gives the administering authority "full powers of administration, legislation, and jurisdiction" over the territory, and the power to "establish naval, military and air bases and to erect fortifications" in the territory, as well as other broad powers with respect to security. ${ }^{50}$ By some curious criterion of construction, none of the powers of the administering authority are relevant in ascertaining the extent of its duties: the latter are "unqualified imperatives."

The United States' only alternatives, these critics conclude, are to cease further testing altogether, or to conduct tests in a manner which is "compatible with the basic general tenets of international law, and the specific provisions of the United Nations Charter and the Trusteeship Agreement." done "only . . . by conducting them . . . within the . . . United States, or Alaska, or somewhere within the Arctic Region in the 'sector' north of Alaska."53

It is our belief that all of these arguments are unsound in law and in policy, and we propose to refute them seriatim.

\section{The Regime of the High Seas-A Process of Codrarunity Protection of Unilateral Claiars}

\section{The Process of Asserting and Adjusting Clains}

Throughout the centuries of its development, one may observe the regime of the high seas ${ }^{54}$ as, not a static body of absolute rules, but rather a living,

46. Ibid.

47. Ibid.

48. Id. at 645 and $\mathrm{n} .86$.

49. Id. at 645 .

50. Trustership Agreearent arts. $3,5,13$.

51. Margolis, p. 644. For a comparable line of argument, see the Striet and Indian representatives' remarks in U.N. Trusteeship Couxcil OfF. Rec., 14th Sess., Folst meeting 243-47 (1954). Mr. Singh of India emphasized that the conducting of hydrugen bomb tests was not specifically listed in the Agreement as one af the things that the Administering Authority could do in the territory. Id. at 246.

52. Margolis, p. 646 .

53. Id. at 646-47. See also Arnold, Effects of the Recent Bomb Tests on Humas: Bein:ls, 10 Bull. Atoxs. Screntists 347, 348 (1954). Mrargolis, p. 647 n.94, asserts that an Aretic sector has been "claimed" and "occupied" by the United States.

54. The term "high seas" is commonly used both in a factual sense tu describe all 
growing, customary law, grounded in the claims, practices, and sanctioning expectations of nation-states, and changing as the demands and expectations of decision-makers are changed by the exigencies of new social and economic interests, by the imperatives of an ever developing technology and by other continually evolving conditions in the world arena. From the perspective of realistic description, the public order of the high seas is not a mere body of rules, but a whole decision-making process, including both a structure of authorized decision-makers and a body of highly flexible, inherited prescriptions: it is a continuous process of interaction in which the decision-makers of individual nation-states unilaterally put forward claims of the most diverse and conflicting character to the use of the world's seas, and in which other decision-makers, external to the demanding nation-state and including both national and international officials, weigh and appraise these competing claims in terms of the interests of the world community and of the rival claimants, and ultimately accept or reject them.

The competing claims asserted by nation-state decision-makers to the use of the high seas, the events to which the "regime of the high seas" is a response, vary enormously in the comprehensiveness and particularity of the interests sought to be secured, in the location and size of area affected, and in the duration of the claim. They range from the comprehensive and continuous claim to all competence in the "territorial sea," through the continuous but limited claims to navigation, fishing, and cable-laying upon the "high seas," to the relatively temporary and limited claims to exercise authority and control beyond territorial boundaries for a vast array of national purposes: security and self-defense, enforcement of health, neutrality, and customs regulations, conservation or monopolization of fisheries, exploitation of the sedentary fisheries and mineral resources of the seabed and continental shelf, the conducting of naval maneuvers, military exercises, and other peacetime defensive activities, and so on. ${ }^{55}$

It need cause no confusion that the authoritative decision-makers put forward by the public order of the high seas to resolve all these competing claims include, in addition to judges of international courts and other international officials, those same nation-state officials who on other occasions are themselves claimants-that, in other words, the same nation-state officials are

sea areas, whether "territorial sea," "contiguous zones," or whatever, and as a lcgalistic label to describe a part of the seas subject to a regime distinct from those governing other areas of the sea. For lack of an accepted terminology distinguishing these two very different references, we continue in the pages that follow to use the term in both senses, relying upon the context to make clear which meaning we intend in particular instances. Our reference here and in the title to this section is of course the factual onc to all sea areas.

55. This categorization of the claims which nation-state decision-makers assert against each other is not intended to be sharp and precise but rather to identify broad groupings. At their peripheries the categories obviously merge and overlap. The third category, in particular, contains some claims which may be asserted over long periods of time and include a very considerable degree of authority and control. 
alternately, in a process of reciprocal interaction, both claimants and external decision-makers passing upon the claims of others. This duality in function ("dédoublement fonctionnel") merely reflects the present lack of specialization and centralization of policy functions in international law generally." Similarly, it may be observed, without cause for deprecation or shocked averting of the eyes, that these authoritative decision-makers projected by nation-states for creating and applying a common public order, honor each other's unilateral claims to the use of the high seas not merely by explicit agreements but also by mutual tolerances-expressed in countless decisions in foreign offices, national courts, and national legislatures-which create expectations that power will be restrained and exercised in certain uniformities of pattern. ${ }^{57}$ This, too, is but the process by which in the present state of world organization most decisions about jurisdiction in public and private international law are, and must be, taken. .s

The over-riding policy which infuses this whole decision-making process, perhaps it requires explicit statement, is not the negation of use, but the encouragement of use. The major policy purpose which inspires the regime of the high seas is not merely the negation of restrictions upon navigation and fishing but also the promotion of the most advantageous-that is, the most conserving and fully utilizing-peaceful use and development by all peoples of a great common resource, covering two-thirds of the world's surface, for all contemporary values. ${ }^{53}$ The concept of a common and reciprocal interest in fullest utilization underlies the whole flow of decision.

56. Schiffer, The Legal Cominuitr of Mlankind 204 (1954), expunding the views of Georges Scelle.

57. When Dr. Margolis insists that "special police powers are created unly by treaty," Margolis, p. 634, he over-emphasizes the role of agreement. The great bulk of particular claims to authority and control upon the high seas is honored and protected, as the text below will abundantly demonstrate, not by explicit bilateral or multilateral agreements but by reciprocal tolerances expressed in the continuous flow of dccisions about such clains.

58. This process of unilateral claim and reciprecal tolerance with respect tu authority over particular value changes, indispensable to the stability in expectations and puwer calculations of nation-state decision-makers, operates easily through the complementarit: and ambiguity of prescriptions cast in terms of "territuriality," "nationality" "passive personality," "universality," "jurisdiction," "choice-of-law," "act of state," "immunity," and so on. See MicDougal, International Law, Powir, and Poliry, 82 Hage Acubésiz de Drott Interdiational, Recueil des Couss (hereinafter cited as Haguc Keiteil) 137, 213 (1953) ; Niboyet, Territoriality and Unizersal Recognition of Rules of Confiet of Laws, 65 Harv. L. Rev. 582 (1952) ; Yntema, The Historic Bases of Prizate Infernational Law, 2 Axr. J. Coxrp. L. 297 (1953) ; Comment, "Att of State" Immunily, 57 YALE L.J. 108 (1947) ; Comment, The Jurisdictional Immunily of Foreigns Secereigns, 63 YALE L.J. 1148 (1954).

59. Appropriate emphasis upon a positive policy uf prumuting, rather than restricting, use may be found in Lauterpacht, Socereignty oecr Sulnurine Arcas, 27 Bnit. Y.E. IXT'L L. 376, 378, 407 et seq. (1950); and in the U.N. Secretariat, Keyime of the High Seas, U.N. Doc. No. A/CN.4/32, at 10, 12 (1950) (memorandum to the Int'l Law Comm'n) (hereinafter cited as Gidel, Memorand:mb). (It is widely lunown that this im- 
For pursuing this major policy purpose in regulating the maze of conflicting claims which confront them, the authoritative decision-makers of the world community have elaborated that comprehensive body of complementary prescriptions which makes up "the regime of the high seas." One set of these prescriptions, that generally referred to under the label of "freedom of the seas," was formulated, and is invoked, to honor unilateral claims to navigation, fishing, cable-laying, and other similar uses. ${ }^{60}$ The other set, that which includes the prescriptions summed up in a wide variety of technical terms such as "territorial sea," "contiguous zones," "jurisdiction," "continental shelf," was formulated, and is invoked, to honor all the great variety of claims, both comprehensive and particular, which may interfere, in greater or less degree, with navigation and fishing. ${ }^{61}$ To the initiated it is not surprising that the technical terms in which both sets of these prescriptions are formulated are at the highest level of abstraction and, hence, ambiguous in highest degree. A decision-maker confronted with the task of deciding upon the lawfulness of a challenged claim to the use of the seas must create meaning for these terms and must turn to other sources for detailed policy guiclance. The sources to which such a decision-maker, like the judges of the International Court of Justice, is authorized, and may be required by the necessities of policy clarification, to turn include not only "international conventions, whether general or particular, establishing rules expressly recognized by the contesting states," but also "international custom, as evidence of a general practice accepted as law," "the general principles of law recognized by civilized nations," "judicial decisions and the teachings of the most highly qualified publicists of the various nations," and considerations "cxt aequo et bono." 62

The great ambiguity of the constituent technical terms in the principal prescriptions and the wide variety of authoritative policy sources accorded to the

portant study is the work of Gidel, although the author is not identified in the publication itself. See Briggs, The Law of Nations 383 (2d ed. 1952); 1 Guggenhein, Traité de Droit International Public 391 n.3 (1953); Lauterpacht, supra, at 408 n.1.)

60. See text at notes 68-84 infra.

61. See the sections on "Territorial Sea," "Contiguous Zones," and "Security" claims, text at notes 85-103, 104-43, 144-91 infra, respectively.

62. Stat. InT'L Cт. Just. art. 38.

It is our purpose in this explicit and comprehensive listing of authorized sources of policy to emphasize that the authoritative decision-makers of the public order of the high seas are not confined in their determinations of lawfulness either to explicit agreements bctween the parties or to inferences from prior customary behavior, but may also take into account a great variety of principles, precedents, analogies, and considerations of fairness. The role established for such a decision-maker is not that of the automaton but rather of the creative deliberator, who is permitted and expected to draw upon the wisdom of the past, but is not required to respond compulsively to new problems in living contexts as if they were old problems in dead contexts.

Gidel refers to the "wider significance" of "the unilateral act" and describes it as "onc of the means by which international custom is formed." Gidel, Mcmorandum 90 . It is not, however, necessary in accurate description of the regime of the high seas to take the position 
authorized decision-makers have given, and continue to give, to such decisionmakers, a very large discretion to adjust particular controversies in terms of the multiple variables peculiar to each controversy and thus to promote the overriding policy of full-utilization. The degree to which decisions for the last century and a half, because of common interest in the sea as an efficient medium of communication and as an abundant source of food, have given a high priority to claims for freedom of navigation and fishing, is sufficiently emphasized in conventional literature. ${ }^{.3}$ It is equally common knowledge, however, though on occasion reluctantly admitted, that a parallel flow of decisions has protected a great variety of claims to authority and control on the high seas for the protection of security, health, revenue laws, economic welfare, and so on, even against protests that they interfere with navigation and fishing, and that a still higher priority is accorded to claims of "sovereign" competence in "territorial seas" despite such interference. ${ }^{\text {Bf }}$ It has been recognized in decision, if not in the justifications summarized in the textbooks, that all of these claims, those to navigation and fishing and those that may interfere, are of a common character: they are all unilateral assertions by particular claimants to individual use of a great common resource and all such assertions are affected in equal degree-navigation and fishing no more or no less than the others-with community interest in fullest utilization and conservation, and with national interest, which, though possibly varying with geographical propinquity in particular instances, is in the sum of all instances common to all claimants. ${ }^{65}$ The technical prescriptions of the "freedom of the seas," on the one hand, and of "territorial sea," "contiguous zone," "juris-

that unilateral claims to the use of the seas of themselves establish their own lawinlness. It is not the unilateral claims to use but rather the tolerances of external decision-maliers, including the specific decisions of international officials, which create the expectations of pattern and uniformity in decision, of practice in accord with rule, commonly called law.

An excellent recent example of the interrelation of roles, which we here seck to describe, between unilateral claim and external decision is found in the Anglo-Norwegian Fisheries Case, Judgment of Dec. 18, 1951, [1951] I.C.J. Rep. 116. In this case Norway asserted claims which could not be justified by reference to either explicit agreement or videly accepted custom, see generally Waldock, The Anglo-Nomicgian Fisheries Case, 23 Bnir. Y.B. INT'L L. 114 (1951), but by drawing upon all relevant sources of policy and a great variety of considerations in the context, the International Court of Justice concluded, despite the protests of other nation-states, that Norway's claims were lawivl. This decision by the International Court of Justice merely exemplifies the process of decision-maling-the process by which policies are both created and applied-common to the whole regime of the high seas, whether decision is by international or national officials and whether the claims are important or unimportant, and whether unique or commonplace.

63. See text at notes $68-84$ infra.

64. See text at notes $85-103,104-43,144-91$ infro.

65. Our purpose here is to emphasize that it is impossible in accurate description to distinguish some claims as "unilateral" and some as not, and difficult, if not impossible, in rational preference to order claims in some hierarchy of degrees of community interest valid for all problems and contexts. The relevance to policy of prupinquity of use to shure will be assayed below. See note 204 infra. For discussion of traditiunal distinctions, see Mouton, The Continental Shelf 185 (1952). 
diction," and so on, on the other, are not arbitrary, inelastic dogmas, but rather are highly flexible policy preferences invoked by decision-makers to record or justify whatever compromise or adjustment of competing claims they may reach in any particular controversy. And for all types of controversies the one test that is invariably applied by decision-makers is that simple and ubiquitous, but indispensable, standard of what, considering all relevant policies and all variables in context, is reasonable as between the parties." The all-pervading importance of this test of "reasonableness" for resolving competing claims to authority and control on the high seas has been well indicated by Professor H. A. Smith, who, though as spokesman for official British policy is most opposed to extension of national power beyond territorial seas, writes:

"The law of nations which is neither enacted nor interpreted by any visible authority universally recognized, professes to be the application of reason to international conduct. From this it follows that any claim [ to assert power outside the 3-mile limit] which is admittedly reasonable may fairly be presumed to be in accordance with law, and the burden of proving that it is contrary to law should lie on the state which opposes the claim." 67

Without accepting Professor Smith's explanation for the use of reasonableness as a criterion, one may yet applaud the accuracy of his summary of decision-makers' perspectives.

The sections of this article which immediately follow are intended to suggest the broad outlines of relevant world prescriptions regulating the use of the high seas and to indicate in greater detail the process of decision. It will be observed that the emphasis of decision-makers upon "reasonableness" as a criterion has required them to accord a very high deference to claims to security, as against claims to unhampered navigation and fishing, in contexts of high expectations of violence. It will be made clear that the hydrogen bomb tests contravene none of the fundamental policies which underlie the "freedom of the seas" and come easily within the policies which have in the past sanc-

66. This generalization will be documented in detail throughout the five sections which follow. For exposition of the principle see Gidel, Memorandum, passim; Lauterpacht. Sovereignty over Submarine Areas, 27 BRIT. Y.B. INT'L L. 376 (1950). See also Hanvam Research Draft on Territorial Waters 333 el seq. (1929); Jessup, LAw of 'Terimtorial Waters 91-101 and passim (1927); Masterson, Jurisdiction in Marginal SEas xiii-xviii, 375 et seq. (1929) ; Bingham, Juridical Status of the Continintal Shelf, 26 CALI1. L. Rev. 4 (1952) ; Briggs, Les Etats-Unis et la Loi de 1935 Sur la Contrebande-Iitude de la Zone Contiguë et des Critíres de Raisomabilité, 20 Revue de Droit InTtenntronal. er de LéGisLation Conparée (herinafter cited as R.D.I.L.C.) 3d Ser. 217 (1939); Brown, Protective Jurisdiction, 34 AN. J. INT'L. L. 112 (1940); Dickinson, Jurisdiction at the Maritime Frontier, 40 Harv. L. Rev. 1 (1926) ; Jessup, The Alti-Smuggling Act of 1935, 31 Am. J. INT'z L. 101 (1937); Masterson, The Hemisphere Zone of Security and the Law, 26 id. 860 (1940); Y'ntema, Validity of Hovering Legislation in International Law, in Hearings before the House Committee on Ways and Means on H.K. 5496, 74th Cong., 1st Sess. 82 (1935).

67. Smith, The Law and Custom of the Sea 20 (1950). 
tioned the greatest variety of claims more seriously interfering with navigation and fishing. It will, therefore, be concluded that the relevant world prescriptions and the process of decision-making, taken as a whole, clearly enable, and perhaps even require, decision-makers external to the United States, whether national or international, to recognize and affirm that the hydrogen bomb tests are reasonable, and hence lawful, within the regime of the high seas.

\section{The Great Range of Unilateral Claims Honored In CoMraronity Practice}

\section{Clains to Navigation and Fishing: Freedom of the Seas}

The concept of "freedom of the seas" entered the law of nations as a reaction against broad claims to territorial sovereignty over vast sea areas put forward by Spain, Portugal, England, and other states in the sisteenth and seventeenth centuries. The object of these claims was to monopolize fisheries, and trade with areas thought particularly rich in resources. Grotius and his successors entered the fray in behalf of their own states' unilateral claims to navigate, to trade, and to utilize the resources of the sea. ${ }^{\text {cs }}$

The arguments Grotius asserted were as sweeping as the claims of his adversaries. No interference whatever with navigation was justified because effective occupation was impossible by the nature of the sea itself. principle was applicable to fisheries, not only because natural law denied property rights in the resources of the sea until they were reduced to possession, but for the additional reason that the resources of the sea were inexhaustible. ${ }^{70}$ Spain, Portugal, and England were guilty of monstrous greed, he said, because they could not possibly put to constructive use the vast areas they had claimed, but sought only to exclude others. ${ }^{71}$ The claim of the Dutch to free navigation and fishing, on the other hand, could not possibly interfere with free use of the same resources by others. ${ }^{22}$ It is familiar history that common interest in navigation and fishing triumphed over monopoly, and that the great principle of "freedom of the seas" became in this sense universally accepted.

68. Grotius, Freedoas of the Seas vi (Magoffin trans. 1916). For accounts of the series of controversies in which Grotius and his successors participated, see Fulrox, Tue Soveretgnty of the Sea c. 9 (1911); 1 Gidel, Drolt International Pundic ne la Mem $127-48$ (1932) ; 1 OppeNhem, Interanational Law \$\$ 248-51 (7th cd., Lauterpacht 1948) (hereinafter cited as Oppennem-Lauterpacht): Potter, the fremon of the Seas c. 4 (1924).

69. For exposition and analysis of the reasoning, involving a distinction between ownership and sovereignty, by which Grotius reached his conclusions, see Fulro:s, op. cit. supra note 68, at 345 et seq.; Riesenfeld, Protection of Coustal. Fismeries t'suer I:TERNATIONAL LAW 15-18 (1942).

70. Fultox, op. cit. supra note 68, at 345; Riesexfeld, op. cil. supra note 69, at 12, 16.

71. Grorius, op. cit. supra note 68, at 38 .

22. Ibid. 
The natural law arguments put forward by Grotius have long since ceased to be persuasive, and nearly every fact from which he argued has significantly altered. It has long been clear that vast areas of the sea could in fact be occupied, in the sense that others could be effectively excluded by shore batteries, and by naval and air forces armed with modern weapons. Moreover, it is no longer true to say that complete freedom of navigation and fishing cannot possibly interfere with free use of the seas by others. Modern vessels, independent of wind and weather conditions, throng trade routes which follow the shortest and safest track between ports, and collisions are not infrequent. ${ }^{73}$ Vessels similarly interfere with the navigation of others by trawling, dredging, or engaging in dangerous naval maneuvers and military exercises, and they discharge oil waste that fouls beaches and destroys marine life. ${ }^{74}$ Contemporary technology has demonstrated that the resources of the sea are by no means inexhaustible, and more than once the free use of dangerously efficient new methods has threatened to destroy valuable fishery resources forever. ${ }^{75}$ Manifold national interests of critical importance no longer cease at the shore or near it, and have come to affect not only pirates, invading military forces and smugglers, but innocent passersby as well.

Yet despite the remarkable changes which have occurred since Grotius' time, the concept of "freedom of the seas" has not disappeared from world prescription because it still crystallizes one of the two complementary sets of sound community policies, each limiting the other, by which decision-makers resolve conflicting claims to incompatible uses of a common resource. To be sure, ships at sea are regulated by the rules of the road $\mathbf{7 0}^{\mathbf{7 0}}$ ships that require space can get it by making appropriate signals, ${ }^{77}$ and governments disseminate warnings which enable merchant vessels to avoid naval ships engaging in dangelous maneuvers. ${ }^{78}$ Fishery conservation is increasingly enforced on the high seas by individual states, ${ }^{79}$ as are regulations designed to prevent pollution, ${ }^{80}$ and to implement the policies of individual states in innumerable other ways. But it remains true that the world community as a whole has an important,

73. Hilbert, International Rules of the Road at Ses vii-viii (1938).

74. See text at notes 172-84 infra; Final Act of the 1954 International Conference on Pollution of the Sea by Oil, Annex, Resolution 1 (mimeo unchecked copy 1954) (on file in Yale Law Library); Mouton, The Continental Seelf 186 (1952).

75. Gidel, Menorandum 38-39.

76. Hilberx, op. cit. supra note 73, passim; SMITH, op. cit. supra note 67, at 61-62. The courts of most nations assume jurisdiction over collisions occurring on the high sens irrespective of the nationality of the vessels. The Belgenland, 114 U.S. 355, 369 (1885); The Scotland, 105 U.S. 24, 29 (1881) ; Chartered Bank v. Netherlands Steam Navigation Co., 10 Q.B.D. 521 (1883); Lauterpacht, supra note 66, at 407.

77. Hilbert, op. cit. supra note 73, passim; 1 International Code of Signals passim (1931).

78. See text at notes 173-84 infra.

79. See text at notes 120-24 infra.

80. See François, Report on the Regime of the Territorial Sea 12 (U.N. Doc. No. A/CN.4/53) (1952) (Report to Int'l Law Comm'n). 
continuing interest in encouraging the greatest practicable freedom of navigation and fishing, and the unilateral claims of states to make such uses of the sea for their own benefit continue to be preferred over other unilateral claims which serve community interest in less degree.

"Freedom of the sea" is, thus, no absolute, and never has been. ${ }^{81}$ It is, as it was in the beginning, a legal conclusion invoked to justify a policy preference for certain unilateral assertions as against others. ${ }^{62}$ The clains it favors are those to the utmost freedom for navigation, fishing, and other pursuits thought to further the most productive use of the sea and its resources, and thus to promote the community interest. ${ }^{83}$ It combats monopolistic claims, and minimizes international friction by confining each state's regulatory power, where possible, to ships flying its own flag, thus avoiding wrangles over seizure of ships and crews and other incidents of enforcement. ${ }^{84}$

\section{Continuous and Comprehensive Clains: The Territorial Sca}

The most familiar group of demands which conflict with claims to navigation and fishing are certain continuous claims to exercise a "bundle of competences" termed "sovereignty" over a littoral belt of waters called the "territorial sea." 85 Although the right of states to claim a territorial sea has not been seriously questioned since the early nineteenth century, ${ }^{80}$ the conflict between competing claims in this area is still so sharp that the most basic elements of possible compromise are still unsettled. Not only is the width of the area which may be claimed still disputed, but also the baseline from which this unknown width must be measured, and the very degree and scope of the

81. For excellent recent statement, see Lauterpacht, Socercignty oicr Submarinc Areas, 27 Brit. Y.B. INT'L L. 376, passim, but especially 399, 403-10 (1950); Gidel, Menorandum 74, 112.

82. "Freedom of the seas" has, of course, been most strongly supported by large maritime states and less enthusiastically by nations with predominantly coastal interests. Sce Potter, The Freenont of the SeAs c. 11 (1924); Boggs, National Clains is Adjacen' Seas, 41 Geographical REv. 185, 203-04 (1951). The national interests which have underlain most historic assertions of "freedom of the seas" are sufficiently obvious. For citatiuns see note 68 supra; cf. Gidel, Menrorand $u m$. 3.

83. See Lauterpacht, supra note 81, at 407. Navigation and fishing are not "corullaries" of the principle of freedom of the seas, as Dr. Margolis suggests, Maryalis, p. 630, but the primary reference of the words. It is commonplace, however, that "ircedum of the seas" may be invoked to justify uses of the seas other than navigation and fishing, and that any and all uses may limit the freedom of other users. See Movton, TnE Co:trixe:is.u. ShelF 185-87 (1952).

84. Lauterpacht, supra note 81 , at $403-04,408$.

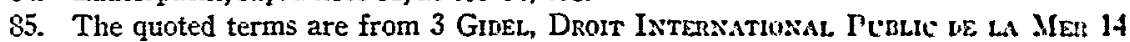
(1931). For citation to the few authorities who continue to debate whether the powers exercised in territorial sea by littoral states amount to "sovereignty" or something less, see François, Report on the Regine of the Territorial Sea 7-8 (U.N. Doc. No. A/CN.4/53) (1952) (Report to Int'l Law Comm'n).

86. Kent, The Histarical Origins of the Three-Mile Limit, 48 Axs. J. Isr'L L 537 (1954). 
authority that may be exercised within the area once its limits are ascertained.

From the beginning of the modern law of the sea, it has been recognized that the reasonable needs and interests of littoral states required that they be permitted to extend their boundaries some distance seaward, and that protection of this claim was more in accord with community interest than were the inconsistent claims of states to unimpeded use of the seas for all. Grotius cautioned that his principle of freedom of the seas applied only to the "sea, properly speaking," not to bays and straits or to seas adjacent to the shore.87 As the interests of states crowded outward, first exclusive fishing rights, then neutrality, and later all the interests which a sovereign state may act to protect were recognized to justify national claims to adjacent seas..$^{88}$ Bynkershoek's cannon-shot rule and Scandinavian claims to an all-purpose zone of measured-width were at one with community interest: they fused to form the body of prescriptions summed up in the term "territorial sea."80

Although more than 300 years have passed since Grotius published his famous brief, it is still not possible to say much more than that the regime of the high seas applies only to the "sea, properly speaking," not to "territorial seas." Although several large and influential states, among them the United States, have consistently maintained that the maximum seaward extent of the territorial sea should be three miles, a much larger number of states and virtually all publicists agree that the "three-mile rule" is valid only as a minimum. ${ }^{90}$ Some thirteen states accept the three-mile rule for one or more purposes, while some forty-five states repudiate it in greater or less degree. ${ }^{91}$ The 1930 Conference for the Codification of International Law brought to light the extent of the disagreement between states on the permissible width of territorial waters, ${ }^{02}$ and in the intervening years, as the discussions in the International Law Commission bear witness, the gap ap-

87. Grotius, Freedom of the Seas 37 (Magoffin trans. 1916). The quoted words are from Wright's translation, quoted in Riesenfeld, Protection of Constal Fisuentis UNDER INTERNATIONAL. LAW 18 (1942).

88. Pontanus, a fellow-countryman of Grotius who carried on the Grotius-Selden controversy over fishing rights, conceded in 1637 that adjacent seas could be subjected to ownership and exclusive jurisdiction. Id. at 19-20. For later historical development, sec Kent, supra note 86, passim; Walker, Territorial Waters: The Cannon Shot Rule, 22 Brit. Y.B. INT'L L. 210 (1945). Nation-states are now, of course, conceded to enjoy "sovereign" rights over territorial seas. See Briggs, The Law of Nations 281-84 (2d ed. 1952); Harvard Research Draft on Territorial. Waters 243 et seq. (1929) ; International Law Commission, Report, U.N. General Assejubly Off. Rec., 9th Sess., Supp. No. 9, at 13-14 (Doc. No. A/2693) (1954).

89. Kent, supra note 86 , at 552-53; Walker, supra note 88 , at $228-31$.

90. For collection of state practice and citations, see François, supra note 85, at 11-21.

91. Id. at $18,11-15$.

92. Gidel has called the three-mile rule "la grande vaincue de la Conférence," and added, "Il est désormais impossible de parler de la règle des trois milles comme constituant une règle de droit international commun positif." 3 Gidel, Droit International, Publac DE LA MER 151 (1934). 
pears to have widened. ${ }^{93}$ Even in the countries which adhere to the threemile rule there is widespread dissatisfaction with its operation. Bingham spoke the preference of many when he said, "The irresistible tide of economic, political and social interests is running against the Anglo--American three-mile doctrine. It is doomed."

A striking recent illustration of the flexibility of the international prescriptions relating to the territorial sea is the Anglo-Nori'egian Fishcries $\mathrm{Case}^{95}$ in which the United Kingdom attacked Norway's system of measuring its four-mile territorial sea from straight baselines instead of the low water mark following roughly the sinuosities of the coast. The International Court upheld Norway's system upon broad grounds of reasonableness, although that system was almost unique in the practice of states and extended Norway's exclusive fishing rights over a considerable area beyond that afforded by the traditional method of delimitation. Norway's straight baselines were valid, said the court, because they were adapted to its "practical needs and . . requirements." The court emphasized the unusual geographic configuration of the coast, and "economic interests peculiar to [the] region, the reality and importance of which are clearly evidenced by a long usage." Noting the "general toleration of foreign States" over an extended period, the court held that the Norwegian system could not be considered an unreasonable infringement of the rights of others. ${ }^{97}$ Judge Alvarez, concurring, was most explicit:

"Each State may ... determine the extent of its territorial sea and the way in which it is to be reckoned, provided it does so in a reasomable manner, that it is capable of exercising supervision over the zone in question and of carrying out the duties imposed by international law. that it does not infringe rights acquired by other States, that it does no harm to general interests and does not constitute an abus de droit."

Within territorial seas, nation-states may monopolize fisheries, may apply their general legislation almost as fully and freely as they do within their

93. See, e.g., International Law Commission, Prozisional Summary Rccords (L.X. Docs. Nos. A/CN.4/SR.164-72) (1952).

94. Bingham, Changing Concepts of International Law: Maritime Jurisdistiun in Time

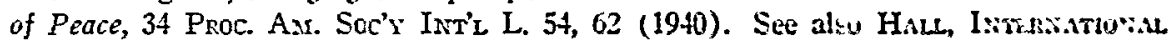

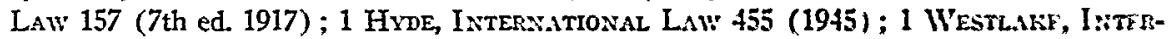
Natronal Law 18S-89 (1910); Borchard, Resourees of the Cuntinental Shelf, 40 Ax. J. INT'L L. 53, 61 (1946) ; Brown, The Law of Territorial Wafers, 21 id. 101 (1927): Brown, The Marginal Sea, 17 id. 89 (1923).

One need not, however, agree with these statements of preference, since must if nut all legitimate ends may be adequately secured by less comprehensive elaims of the type described in text at notes $104-43$ infra. For full discussion, sce Opd, Ricues uF ruE SEand INTERNational LaW (unpublished thesis in Yale Law Library 1953).

95. Judgment of Dec 18, 1951, [1951] I.C.J. Rep. 116.

96. Id. at $133,138$.

97. Id. at 138,142 .

98. Id. at 150,153 . 
land boundaries, ${ }^{99}$ and to a certain extent may exclude vessels altogether. ${ }^{100}$ Other states' claims to "freedom of the seas"-that is, to use and enjoy the seas for their own benefit,--become tenuous and vestigial in territorial waters, but are yet too strong to be ignored. The policy preferences summed up in "freedom of the seas" are represented in the law of territorial waters by the doctrine of "innocent passage."101 Thus in the recent Corfu Channel Case, ${ }^{102}$ the International Court, emphasizing that the Channel connected two parts of the high seas and formed part of a heavily traveled maritime route, held that Albania could not deny passage through the strait even to warships, although it might regulate passage. ${ }^{103}$

It is, in summary, obvious that only the flexibility of the relevant prescriptions at the disposal of decision-makers, permitting them to adjust particular decisions to changing needs and conditions, prevents serious friction between nation-states with respect to the riot of conflicting claims within and at the outer boundaries of territorial seas. Within such boundaries, the needs of littoral states for comprehensive governmental powers and the no less important needs of all for open lines of communication and commerce are adjusted by application of "innocent passage" and of appropriate qualifications to that doctrine created as occasion may require. Beyond territorial boundaries and with respect to the multiple important claims to specific and limited competences now extended many miles out to sea, such safety-valve concepts as "contiguous zones," "jurisdiction," "continental shelf," and so on, to which we now turn, prevent the continuing controversy over the seaward extent of the territorial sea from doing serious harm to community and national interest.

\section{Particular Claims for Limited Purposes: Contiguous Zones}

Before the territorial sea had become a familiar concept in internationil law, it was already in some respects obsolete. The modest distances at which

99. For collection of citations on the powers of states within territorial scas, sce Briggs, The law of Nations 281-84 (2d ed. 1952); Harvard Research Draft on Territorial Waters 243 et seq. (1929). See also International Law Commission, Report, U.N. General Assembly OfF. Rec., 9th Sess., Supp. No. 9, at 13-14 et seq. (Doc. No. A/2693) (1954).

100. Id. at 18, art. 20 (2). For U.S. practice, see the Act of June 25, 1942, 56 STAT. 390,50 U.S.C. $\$ 781$ (1952), providing criminal penalties for violation of regulations relating to Defensive Sea Areas. For typical regulations, see Exec. Order No. 8680, 6 FEd. Rec. 1014 (1941), corrected by Exec. Order No. 8729, 6 FED. REG. 1791 (1941), excluding all persons not authorized by the Secretary of the Navy from the territorial waters of Kiska and Unalaska Islands. For collection of all laws and regulations to date relating to Defensive Sea Areas, see U.S. Naval War College, International Law Documents 1948-49, pp. 157-69 (1950).

101. Jessup, LAW OF Territorial Waters 120 (1927).

102. Judgment of April 9, 1949, [1949] I.C.J. Rep. 4; Note, 50 Colun. L. REv. 220 (1950).

103. Corfu Channel Case, Judgment of April 9, 1949, [1949] I.C.J. Rep. 4, 28-29. 
the limits of the territorial sea had tended to crystallize were already inadequate to protect certain pressing interests of littoral states. The attempt to protect these interests took, and even today sometimes takes the form of an attempt to extend territorial waters, but the pressure of community policy, reinforced by the national interests of large and influential states in seas adjacent to foreign coasts, made extension of territorial waters an unacceptable solution. Accordingly, states claimed rights of "jurisdiction" or "control" -less than "sovereignty"-for special purposes, and limited their claims to the minimum distance, the minimum degree of comprehensiveness, and the minimum length of time necessary to effectuate particular purposes. Claims of this nature which were reasonable evoked no significant protest. ${ }^{104}$ Some authorities spoke of "territorial sea for customs," "territorial sea for neutrality," and the like;105 others differentiated the claim to sovereignty within territorial waters, and claims to lesser rights beyond, grouping the latter under the heading "contiguous zones." 100 One of the earlier statements of the fundamental policies which underlie such claims was made by Chief Justice Marshall, in the famous case of Church v. Hubbart, ${ }^{107}$ which recognized the validity of Portugal's claim to exercise authority on the high seas to protect commercial interests in its colony of Brazil. Asserting that the power of a state to secure itself from injury "may certainly be exercised beyond the limits of its territory," the Chief Justice continued:

104. See Lauterpacht, Sovereignty oz'or Submarine Areas, 27 Brit. Y.B. I::T'L L. 376, 406 (1950).

As the following pages will show, the assertion by Margolis, p. 635, that "sovereignty" may not be exercised over high seas areas, is totally irrelevant to the issue to which he addresses himself. If anything is clear, it is that the United States has never elaimed "sovereignty" over any "high seas" areas and has no need to make such a elaim in order to justify the control it seeks for the hydrogen bomb tests. See test at notes $192-93$ infra. It is altogether impossible to comprehend the contemporary law of the sen without distinguishing between the comprehensive and continuous rights of "sovereignty" claimed only" within "territorial seas" and the lesser rights claimed under other labels beyond. Hyde in his Foreword to JesSUP, LAw of TerRITORIAL WATERS ix (1927), spealis of "the important distinction observed by maritime states between claims assertive of territorial control over particular waters, and claims of purely jurisdictional aspect asserted through acts committed on the high seas." Jessup himself has said: "There is a vital distinction between that maritime belt which is claimed as a part of the territory of the state and the limited rights of control or jurisdiction claimed upon the high seas." Id. at xwxiii. See also ALssterson, Jurisdiction in Miarginal Seas xiii-xviii, 375 et seq. (1929); Briggs, Les EtatsUnis et la Loi de 1935 sur la Contrebande-Etude de la Zone Contignế et des Crilćres de "Raisonnabilite", 20 R.D.II.C., 3d Ser. 217, 231-32 (1939); Gidel, Lo Jler Territoriole et la Zone Contiguë, 48 HAGue RecueIl 137 (1934).

105. Martial, State Control of the Air Sface over the Territorial Sca and the Contiguous Zone, 30 CAN. B. Rev. 245, 254 (1952).

105. The term "contiguous zone" did not come into general use until the Codifieation Conference of 1930 . See Gidel, sifra note 104, at 138 et seq. The concept itself is, of course, very much older, as will be seen infra.

107. 6 U.S. (2 Cranch) 187 (1804). 
"Any attempt to violate the laws made to protect this right [to monopo" lize colonial trade], is an injury to itself, which it may prevent, and it has a right to use the means necessary for its prevention. These means do not appear to be limited within any certain marked boundaries, which remain the same, at all times and in all situations. If they are stuch as unnecessarily to vex and harass foreign lawful commerce, foreign nations will resist their exercise. If they are such as are reasonable and necessary to secure their laws from violation, they will be submitted to.

"In different seas, and on different coasts, a wider or more contracted range, in which to exercise the vigilance of the government, will be assented to. Thus, in the channel, where a very great part of the commerce to and from all the north of Europe, passes through a very narrow sea, the seizure of vessels . . must necessarily be restricted to very narrow limits; but on the coast of South America. seldom frequented by vessels, . . . the vigilance of the government may be extended somewhat farther ; . . foreign nations submit to such regulations as are reasonable in themselves ..."

It is this concept of a reasonable competence beyond territorial seas which most clearly reveals that enduring flexibility which permits the regime of the high seas to meet the changing needs of contemporary life.

The first national interest clearly to escape the confines of the territorial sea was, typically, that of the fisc. Beginning at least 250 years ago, states began to exercise rights of jurisdiction and control upon the high seas in order to enforce their customs laws, in zones ranging from six to three hundred miles from shore. ${ }^{100}$ Britain, a staunch supporter of the three-mile rule, as recently as 1876 claimed a customs zone of three hundred marine miles, and today exercises limited jurisdiction twelve marine miles from shore. ${ }^{110}$ Since 1790 , the United States has maintained a contiguous zone for customs control of twelve nautical miles, ${ }^{111}$ and since 1935 has provided by law that whenever the President finds that an area on the high seas autside customs waters is frequented by hovering vessels, he may create "customs enforcement areas" extending sixty-two miles from shore for a distance of two hundred miles along the coast. ${ }^{112}$ At least twenty-six states claim a contiguous zone, outside

108. Church v. Hubbart, 6 U.S. (2 Cranch) 187, 234 (1804). On the interpretation and significance of this case, see Dickinson, Jurisdiction at the Maritime Frontier, $40 \mathrm{HARv}$. L. Rev. 1, 4 et seq. (1926). See also Hudson v. Guestier, 8 U.S. (4 Cranch) 293 (1808): The Vinces, 20 F.2d 164, 172 (E.D.S.C. 1927) ; Croft v. Dunphy, [1933] A.C. 156; Naim Molvan v. Attorney-General for Palestine, [1948] A.C. 351, 369.

109. See MASTERSON, op. cit. supra note 104, at 1-120, 175-247.

110. Id. at 1-161; Masterson, The Hemisphere Zone of Sccurity and the Laze', 26 A.B.A.J. 860,861 (1940).

111. 1 STAT. 156 (1790).

112. Anti-Smuggling Act of 1935, 49 STAT. 517, 19 U.S.C. § 1701 (1952). For exercise by the President of his authority to create customs enforcement areas, see Proclamations Nos. 2131,49 Stat. $3462(1935) ; 2132$, id. at $3464 ; 2149$, id. at $3484 ; 2150$, id. at 3485 ; $2152, i d$. at 3488 . Cases of seizure of ships under this Act are discussed in Briggs, supra note 104, at 248-55.

For careful demonstration of the compatibility of this Act with international law, and 
territorial waters, for customs enforcement purposes. ${ }^{113}$ A recent report to the International Law Commission does no more than recognize the obvious when it states that "it would be impossible to dispute the right of states to institute a contiguous zone for Customs purposes."11:

Another interest achieving early protection was that of security of neutral states against belligerent activities. As the range of weapons of war increased, coastal states were forced to claim extended rights of jurisdiction and control over the high seas in order to protect their shores from injury by foreign vessels in combat. In the famous incident of the Alabana and the Kcarsarge during the American Civil War, the French authorities prevented an engagement between the two ships just outside French territorial waters, and escorted the Alabanza some distance out to sea where a battle eventually took place. ${ }^{115}$ Other states extended neutral zones from time to time as occasion demanded, until, by the Declaration of Panama of 1939, the governments of twenty-one American republics asserted an "inherent right" to have the waters "to a reasonable distance from their coasts" remain "free from the commission of hostile acts and from the undertaking of belligerent activities" by nations engaged in war. 116 This "security zone" encircled the United States and Central and South America, embracing the waters of the Atlantic and Pacilic for distances ranging from 300 miles off the tip of South America to some 1200 miles off the coast of Florida.117 Although on several occasions the zone was violated, and in response to protests the belligerents challenged its

documentation of the standard of reasonableness, see Yntema, Iolidity of Hoicrity Legislation in International Law, in Hearings before the House Committe on IIays and II cans on H.R. 5496, 74th Cong., 1st Sess. 82-124 (1935). See also Jessup, The Anti-Swatyllisty Act of 1935, 31 Axr. J. INT'L L. 101, 105 (1937): "In short, Prufessor Yitems and the Treasury Department argued that the only test of the extent to which a natiun may extend its jurisdiction in proximate areas of the high seas is the test of rensonableness. It is believed that this is a sound position under international law." Gidel, Memarandum 30-31, emphasizes technological factors, such as the increased speed of ships, and the fact that the Act is limited in both duration and degree of comprehensiveness, to justify the large area claimed, and concludes that, "nothing could be further from a claim of the old-fashioned kind to 'sovereignty' over the high seas." See also Briggs, sturg note 104, at 240-55; Roberton, Anti-Smnggling Bill-Jurisdiction on the High Scas, 35 Mircu. L. Rev. 1140 (1937).

113. François, Report on the Regime of the Territorial Sca 11-15 (U.N. Doc. No. A/CN.4/53) (1952) (Report to Int'l Law Comm'n). This count does not, of course, include nations claiming territorial seas of four, six, twelve, twenty-five, fifty or two hundred miles, but only those claiming customs zones ontside territorial seas. For texts of most national laws relating to customs zones, see LAws AND REGULATIONS ON THE REGlase of THE HIGH SEAs (U.N. Doc. No. ST/LEG/SER. B/1) (1951).

114. François, supra note 113 , at 49.

115. 1 Moore, Digest of International Law 723-24 (1906). The United States protested this action at the time, but later conceded its correctness. 1 Wrarto:, Drgest of INTERNATIONAT LAW 108-09 (1886).

116. See International Conferences of Axrertcan States, 1933-1940, p. 334 (1st Supp. 1940), reprinted in 34 Axr. J. INTL L. Supp. 17 (1940).

117. Masterson, supra note 110 , at $\$ 60$. 
legality, ${ }^{118}$ the Declaration at least indicates unanimity among the American republics on the principle that authority may be exercised over considerable areas of the high seas in defense of neutrality. Moreover, the opinions of influential publicists indicate that the principle asserted by the Declaration was sound, and that objections to enforcement of the zone could be valid only in so far as its operation in particular instances could be shown to be unreasonable. ${ }^{119}$

The most influential single factor in producing recurrent opposition to attempts to extend the limits of territorial seas has perhaps been the interest of states in fisheries along foreign coasts. Yet the indiscriminate use of trawls, floating factories, explosives, and other potentially destructive fishing methods made possible by modern technology has forced widespread recognition of the legality, if not of extended territorial waters, of contiguous zones for the regulation of fisheries. For years urged only by scholars, ${ }^{120}$ the contiguous zone for fishery conservation was given resounding approval in the historic proclamation of $1945,{ }^{121}$ by which the United States announced a new policy of establishing conservation zones in areas of the high seas contiguous to American coasts. The proclamation contained a variety of provisions sufeguarding the interests of other states in fisheries to be regulated, and an offer to recognize similar rights of control by other states, on condition that the interests of United States nationals be appropriately safeguarded. In addition to the United States, at least twelve other bodies politic assert the right to control fisheries beyond territorial waters. ${ }^{122}$ While the claims of some of these have been widely deprecated, the United States claim has been viewed with approval by many influential commentators. ${ }^{123}$ Most significantly, no

118. For the texts of belligerents' replies see 2 DEP'T STATE BuLl. 199, 201, 203 (19-10).

119. Brown, Protective Jurisdiction, 34 As. J. Int'L L. 112 (1940); Fenwick, Th Declaration of Panama, 34 id. 116; The Exercise of Jurisdiction for Special Purposes in High Seas Areas beyond the Outer Limit of Territorial Watcrs, address by W. W. Bishop, Jr. before the Inter-American Bar Association, May 1949, pp. 4-5; Masterson, supra note 110, at 862-63. Cf. Gidel, Memorandum 34.

Argentina, Brazil, Chile, Colombia, Ecuador, and Peru supported the idea of an equivalent declaration during World War I. See [1914] Foreign ReL. U.S. Supp. 435 at sicl. (1928). For neutrality zones outside territorial waters maintained by the United States during World War I, see the Act of March 4, 1917, 39 Stat. 1194, 99 U.S. OFF. Bull. 8 (1917).

120. See, e.g., Bingham, Report on the Law of Pacific Constal. Fisheries (1938); Riesenfeld, Protection of Coastal Fisheries in International. Law 282 (1942).

121. Presidential Proclamation No. 2668, 59 Stat. 885 (1945).

122. Boggs, National Clains in Adjacent Seas, 41 Geograpuical Rev. 185, 192-98 (1951) ; François, Second Report on the High Seas 50 (U.N. Doc. No. A/CN.4/42) (1951) (Report to Int'1 Law Comm'n).

123. See Gidel, Memorandum 36-48, emphasizing, in support of the reasonableness of the United States claim, advances in technology, the need for conservation, and the fact that the United States claims powers of regulation for conservation purposes, rather than monopoly. Lauterpacht, Sovereignty over Submarine Areas, 27 BrIT. Y.B. INT'L L. 376, 407-08 (1950), asserts the opinion that the U.S. claim is "not necessarily inconsistent with a rational interpretation of the principle of the freedom of the seas so long as its primary 
state has protested the 1945 Proclamation, although a number of states promptly took exception to the more ambitious claims of Chile, Peru, El Salvador, and others. ${ }^{121}$

For centuries states have exercised authority over the high seas in order to regulate sedentary fisheries. Attempts have been made to distinguish these assertions as claims to the sea-bed rather than the seas, ${ }^{125}$ or as mere historical exceptions to freedom of the seas ${ }^{120}$ but licenses have been required, ships seized and jurisdiction assumed over violators of regulations designed to promote conservation or monopoly, and it seems clear that claims of modern origin are as lawful as those of more ancient lineage. ${ }^{127}$ Unilateral claims to exercise national authority over a total of thousands of square miles of high seas for this purpose are today asserted by Ceylon, Australia, Tunis, Ireland, Venezuela, Panama, and states bordering the Persian Gulf. ${ }^{128}$ The International Law Commission has recently indicated that it regards with equanimity the enforcement even of monopolistic regulations. ${ }^{120}$

Perhaps the most spectacular development in the regime of the high seas in recent years has been the quick acceptance of the validity of national claims to the continental shelf. The continental shelf is the gently sloping plain which underlies the high seas adjacent to most land masses, extending seaward from shore to a depth of 100 fathoms. ${ }^{130}$ Discovery of extensive oil reserves under the continental shelf in many areas, and development of techniques of drilling for oil at sea, have given rise to a multitude of unilateral claims to "jurisdiction and control" or "sovereignty" over the

object is not the exclusion of nationals of forcign states," and elsewhere spealis of the "reasonable requirements of economic life and scientific progress," "intrinsic reasonableness," and "the ever valid test of reasonableness." Id. at 403, 406, 407. See also Bingham, The Continental Shelf and the Marginal Belt, 40 Axr. J. IxT't L. 173 (1946); Jessup, The Pacific Coast Fisheries, 33 id. 129 (1939); Selak, Recont Decelopment in High Scus Fisheries Jurisdiction under the Presidential Proclanation of 1945, 44 id. 670 (1950); Allen, The Fishery Proclamation of 1945, 45 id. 177 (1951); Chapman, Unifd Statcs Policy on High Seas Fisherics, 20 Dep't State Bull 67 (1949).

124. Laws axd Regulations ox tae Regiare of the Hign Seis 5, 7, 18 (U.N. Doe. No. ST/LEG/SER. B/1) (1951); François, Fourth Report on the Reginte of the High Seas, Continental Shelf and Related Subjicts 37 (U.N. Doc. Nu. A/CX.t/60) (1953) (Report to Int'l Law Comm'n) ; Comments by Goarrnments 113 (U.N. Dus. No. A/CN.4/19) (1950) (replies to Int'l Law Comm'n questionnaire); Selak, supro note 123, at 673-74.

125. See, $c . g$., Hurst, Whose is the Bid of the Sea?, + Brir. Y.B. Int' L. 34 (1923).

126. See, c.g., Higerns \& Colomeos, International Law uf the Sen $\$ 73$ (2d ed., Colombos 1951).

127. Gidel, Memorandum 73-74; Bingham, Juridical Status of the Continentel Shelf, 26 So. CalIf. L. Rev. 4 (1952); Goldie, Australia's Continental Shelf, 3 I:st'L \& Cous. L.Q. 535, 569-72 (1954).

128. François, Second Report on the High Seas 51-62 (U.X. Due. No. A/CN.4/42) (1951) (Report to Int'1 Law Comm'n).

129. International Law Commission, Roport, U.N. Gexeral Assesrblr: OfF. Rec., 8th Sess., Supp. No. 9, at 14 (Doc. No. A/2456) (1953).

130. See, generally, Botrcart, Grographie du Fonds des Miers, Etvde de Relief des OcÉans (1949). 
continental shelves adjacent to the shores of claimant states. These claims have produced endless discussion by international lawyers and scholars which has been particularly enlightening upon the compatibility of the legal regime of the high seas with activities which necessarily interfere with complete freedom of navigation and fishing.

Development of international prescriptions about the continental shelf began with the Treaty of Paria, ${ }^{131}$ concluded in 1942 between the United Kingdom and Venezuela. Pursuant to the treaty, Britain and Venezuela each annexed one half of the sea-bed of the Gulf of Paria, stipulating, however, that the seas above should retain their legal character as high seas. ${ }^{132}$ In 1945 , in conjunction with the fisheries proclamation, President Truman issued a proclamation declaring that the United States regarded the natural resources of the sub-soil and sea-bed of the continental shelf contiguous to the United States as "appertaining to the United States, subject to its jurisdiction and control."133 The proclamation further provided that the character as "high seas" of the waters above the continental shelf, and the right to free and unimpeded navigation were to be deemed unaffected by the declaration. Subsequently, thirteen nations, nine Middle East sheikdoms and four British colonies have promulgated similar or even more extensive claims. ${ }^{134}$

In spite of the proviso relating to "high seas" in the United States and other declarations, nearly every commentator who has examined the question has conceded that freedom of navigation and fishing must inevitably be affected by development of the continental shelf. ${ }^{135}$ Nevertheless, the opinion of international jurists is nearly unanimous to the effect that no prescription of international law forbids such development, and Lauterpacht, among others, asserts that a customary rule of law permitting jurisdiction and control over undersea areas has by now been established. ${ }^{130}$

Commentators have agreed, first of all, that individual states and the whole world community have a substantial interest in promoting development of undersea resources. ${ }^{137}$ They observe the importance of such resources to lit-

131. Laws and Regulations on the Regine of the High Seas 44 (U.N. Doc. No. ST/LEG/SER. B/1) (1951).

132. Id. at $45-46,47$.

133. Presidential Proclamation No. 2667, 59 Stat. 884 (1945); Laivs and Regula tions on the Regine of the High Seas, op. cit. supra note 131, at 38.

134. Id. at 23-37.

135. See, e.g., Gidel, Memorandum 86; Goldie, supra note 127, at 550-51 (1954); Lauterpacht, Sovereignty over Submarine Areas, 27 Brir. Y.B. INT'L L. 376, 412 (1950).

136. Id. at 376-77, 431; Bingham, Juridical Status of the (ontinental Sticlf, 26 So. CAlif. L. Rev. 4 (1952); Goldie, supra note 127, at 559.

137. The general sexuence of thought indicated in the balance of the text paragraph has been followed most explicitly by Gidel, Memorandum 48-112; Bingham, supra note 136, passim; Lauterpacht, supra note 135, passim. See also International Law Commission, Report, U.N. General Assembly Off. Rec. 8th Sess., Supp. No. 9, at 12-16 (Doc. No. A/2456) (1953) ; Borchard, Resources of the Continental Shelf, 40 Am. J. INT'L L. 53 (1946) ; Briggs, Jurisdiction over the Sea Bed and Subsoil bcyond Territorial Watcrs, 45 id. 338 (1951) ; Brown, Protective Jurisdiction over Marginal Watcrs, 47 id. 452 (1953); 
toral states and the fact that security considerations would impel states to oppose violently any developmental operations near their shores which they could not control, and conclude that the policy of avoiding clashes of interest between states overrides the traditional policy against monopolistic claims. They note that interference with navigation and fishing is certain to ensue, but that such interference would be slight, and in any event would be more than balanced by the interests served by permitting utilization of the resources of the shelf. Frequently, they caution that developmental projects might infringe international law if undertaken in areas peculiarly vital to navigation. In short, the commentators foresee that the interference with other states' claims to rights of navigation, fishing and other uses will ordinarily be rcasonable, and conclude that reasonable claims to use, jurisdiction, control, or even "sovereignty" over the continental shelf are not inconsistent with the regime of the high seas. ${ }^{138}$

Further rich illustration of the practice of states and process of community decision concerning claims in adjacent seas comparable to that with respect to customs, fishing, neutrality, and the resources of the sea-bed and continental shelf, could be offered with respect to virtually every identifiable interest of coastal states. ${ }^{139}$ The most recent information indicates that no less than forty states claim one or more contiguous zones or recognize the validity of claims asserted by others. ${ }^{140}$ It may therefore be observed, as a matter of objective fact, that reasonable claims to contiguous zones for one or more purposes are thoroughly accepted in the practice of states. ${ }^{141}$ The standard of decision with respect to all claims has of necessity been no more explicit than reasonableness, determined ad hoc in the light of all relevant policies, conditions, and alternatives. The maritime frontiers of the world are, thus, not sharp lines between national sovereignty and "anarchy, euphemistically known as 'freedom of the sea," "142 but areas extending beyond terri-

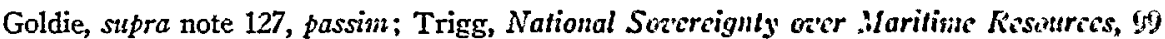
U. PA. L. Rev. 82 (1950) ; Young, Recent Derelopments with Resfect to the Continental Shelf, 42 AMr. J. InT'L L. 849 (1948).

138. With the authorities cited note 137 supra, contrast Margolis, p. 034 , asserting that "the legal justification for such claims is far from clear." Even the International Law" Commission, which has understandably been extremely diffident in endursing priviples nut already estabilished, has adopted articles which would uphold claims to the cuntinental shelf. Report, supra note 137, at 12-16. The Commission stated: "The case is clearly une of assessment of the relative importance of the interests involved. Interference, cven ii substantial, with navigation and fishing might, in some cases, be justificd." Id. at 15. Yet "that principle is in no way incompatible with the principle of freedom of the sea." Id. at 14.

139. See generally Boggs, National Claims in Adjacent Scas, 41 Geoorumarcil Rev. 185 (1951); François, Report on the Regime of the Territorial Sica (U.X. Doe. No. A/CN.4/53) (1952) (Report to Int'l Law Comm'n).

140. Boggs, sutpra note 139, at 192-201; François, sutro note 139, at 11-15.

141. The two-sentence reference to this great development in Margolis, p. 634, is scarcely adequate recognition of its importance.

142. Quoted from Rirsenfeld, Protection of Coast.il Fisaeries under IntersiaTIONAL LAW 2 (1942). 
torial waters for distances ranging up to hundreds of miles, in which states exercise competences of descending comprehensiveness for the most diverse purposes. ${ }^{143}$

Because of their peculiar relevance to the hydrogen bomb tests, the assertion and honoring of claims with respect to defense and security bear further elaboration.

\section{The Special Deference Accorded to Claims ror Security ${ }^{144}$}

In the absence of a centralized authority capable of maintaining public order, nation-states have always demanded for themselves and accorded to others a wide measure of freedom in unilateral action for maintaining their own security against external dictation by unlawful violence or threats of violence. ${ }^{145}$ This has been especially true in the domain of the international

143. One is at a loss to discern the relevance, and even the meaning, of Dr. Margolis' distinction between "general" and "special" police powers. Largolis, pp. 634-36. "The distinction is apparently an effort to force all claims to exercise authority on the high seas into a dichotomy borrowed from Gidel, who used it only to describe certain power's attributed to men-of-war. See 1 Gidei, Droit International de LA Mer 288 ct seq. (1932); Gidel, Memorandum 4, 9-10. The descriptive use of the terms seems to be a shifting reference from the modality by which claims are asserted, to the area in which clains arc - asserted. Thus, "general police powers" may "be exercised independently of treaty rights," emerging " 'purely and simply' from custom" and are not "limited to particular maritime zones." See Margolis, p. 634 n.33. In contrast, "'special police measures' exist onlly by virtue of treaties, and apply exclusively to the states which are parties to them." lliid. Obviously neither description fits the United States claim, but neither does it describe some hundreds of other claims which are of ancient origin and unquestionably lawful.

Only the preferential use of the terms is made completely explicit: the category of "general" police powers is projected as a closed one, confined to certain ancient practices, and all "special" police powers must be created by agreement; hence, decision-makers arc blocked off from honoring any new claims not created by agreement. Ibid. Such preferential projections obviously do not, however, accord with the preferences that the authoritative decision-makers of the world community have embodied in their decisions in the past and no reason is offered why any one should accept such preferences for the future. Certainly the words "general" and "special" are at a level of abstraction which offers no particular policy guidance and vague references to "creation by treaty" and "partictlar maritime zones" adds insufficient factual context to justify any kind of conclusion.

144. "Security" may be most broadly conceived as high position, potential, and expectancy with respect to all values. Lasswell \& KapLAs, Power ANd SOCletr 61. (1950). Thus defined, it underlies all of the claims outlined above, beginning with the claims to navigation and fishing and continuing across the spectrum to claims of sovereignty over territorial seas. For more than usual explicitness in justification of claims to territorial seas and contiguous zones in terms of security, self-defense, and self-preservation, sec Jessup, Law of Territorial Waters passim (1927). Cf. Gidel, Memorandim 45; 12 Fur Seal Arbitration, Proceedings 254-56 (1895).

In this section, however, we use the term "security" in a more restricted sense of frecdom from external dictation by unlawful military violence or threats of violence.

145. Considerations of self-defense and self-preservation have historically played a most important role in the prescriptive formulations of an imperfectly organized world community. See, e.g., 2 Grotius, De Jure Beliz AC PACIs 195 (Kelsey trans. 1925); 3 Vattel, Droit des Gens 149, 274 (Fenwick trans. 1916). See also 1 Fauchille, Tuatté 
law of the sea, where it is with respect to claims which bear upon national security that prescriptions and concepts exhibit their highest degree of flexibility.

The primacy of security interests in the law of the sea is suggested by the historical fact that prescriptions authorizing the unilateral suppression of "piracy"-criminal acts and depredations upon the high seas not attributable to any state-antedate even "freedom of the seas" in its "modern" sense.148 Indeed, the phrase "freedom of the seas" itself was, before Grotius, a popular characterization of efforts to liberate the high seas from the atrocities and robberies perpetrated by pirates. ${ }^{147}$ Because of their common interest in repressing unlawful violence on the high seas the states of the world community have agreed since antiquity that there should be "universal" jurisdiction with respect to piracy. ${ }^{148} \mathrm{~A}$ state may thus exercise jurisdiction over piratical ships and their crews without regard to the locus of the crime, the flag flown, the nationality of injured parties, or any other normal indicia of jurisdiction.140

Of more contemporary importance is the fact that the prescriptions protecting navigation and fishing, like most other important prescriptions in both international and municipal law, have always yielded to claims of self-defense. In the much-discussed case of the Trirginitus, 100 Spanish forces seized an American vessel on the high seas en route to Cuba carrying arms for insurgents, and summarily executed a number of American citizens and British subjects on board. Britain sought reparations for this treatment of its sub-

de Droit International Publtc $\$ 242$ (Sth ed. 1922); H.all, Internatromal L.iw c. 7 (8th ed., Higgins 1924) ; 1 Hyde, Internatronal Law 763 (2d ed. 1945) ; Jessup, Law of Terrttorial Waters 96 (1927); 1 Peillmiore, International Law c. 10 (3d ed. 1879).

Even the most contemporary expression of world organization, the United Nations, confirms and perhaps broadens self-help sanctions against armed attack. See U.N. CEARTER art. 51, which speaks not only of "self-defense," but "collective self-defense." The importance of Article 51 in view of the veto-imposed impotence of the Security Council has often been noted, and the considerations which underlie it find concrete embodiment in the new regional organizations. See generally BeCKetr, The Nortu AтLustric Treaty, the Brussels Treaty, and the Charter of the United Nations 13-15 (1950); Briggs, The Law of Natrons 986 (2d ed. 1952) ; Krlsen, Recent Trends ax tme Law of the United Nations 914 (1951) ; Mlartin, Collective Security: A Progress Repont 169 (1952) ; 2 Oppenhenr-Lauterpacht 156-57; Stone, Legal Controls of Intreraidtronal Conflict 262-65 (1954) ; Bebr, Regional Organizations: A United Nations Problem, 49 Arr. J. InT'L L. No. 2 (1955); Waldock, The Regulation of the Use of Force by Indiviàual States in Intemational Law, 81 HAGUE RecuetL 455, 504 (1952).

146. Gidel, Memorandum 1. For statement of authoritative prescriptions, collection of citations, and discussion see Harvard Researce Draft ox Pir.tcy (1932), printed in 26 AM. J. Int'L L. Supp. 743 (1932); Lenoir, Piracy Cases in the Supreme Court, 25 J. Crtar. L. \& Crniriology 532 (1934).

147. Gidel, Mcmorandum 1.

148. Harvard Researci Draft on Jurisdiction of Crisie art. 9, comment (1935).

149. HaRvard Research, op. cit. supra note 146, at 757; Hanvarn Resentch, of. cit. supra note 148 , at $\$ 63$ et seq.

150. 2 Afoore, Digest of International Law $895-903,980-83$ (1906). 
jects, but conceded the legality of the seizure under the circumstances of the case. ${ }^{151}$ The United States withdrew its initial protest, and subsequently adopted the British view of the right of self-defense as its own. ${ }^{152}$ It is hardly surprising that action in self-defense may be taken on the high seas, since the same principle is considered to justify actual invasion of foreign territory. In the case of the Caroline, ${ }^{153}$ Canadian forces invaded the United States and destroyed the vessel, which was to be employed by Canadian insurgents and American sympathizers in an impending attack on Canada which the United States was unable to prevent. The British in 1807 seized the Danish fleet to avoid its use by Russia, ${ }^{154}$ and in 1940 destroyed the French fleet at Oran to prevent its falling into the hands of German forces. ${ }^{165}$ It is atthoritative community prescription, as well as unilateral claim, that every sovereign state must have, in the words of Elihu Root, "the right . . . to protect itself by preventing a condition of affairs in which it will be too late to protect itself." 156 Since, as has been noted, the world community has no centrally organized police force, self-help is often the only rational alternative for maintaining public order, whether the threat to that order is posed by individuals responsive to the authority of no state, or by the instrumentalities of states themselves.

Claims to contiguous zones for specific security purposes-wholly apart from the preeminence of "security" as a general justification for many different kinds of contiguous zone claims ${ }^{157}$-are today asserted by at least eighteen states, ${ }^{158}$ exclusive of the claims to extensive neutrality zones already considered. ${ }^{150}$ As expectations of the most comprehensive violence have increased in recent years, the number and extent of such claims has increased, with no noticeable protest from the international community.

151. Id. at 983.

152. For espousal by the United States of the doctrine of self-defense upon the high seas, see 12 Fur Seal Arbitration Proceedings 101-04, 246-49 (1895). For approval of the British stand in the matter of the Virginits, see, e.g., BrierLy, The LAW of NATIOns 228 (4th ed. 1949); Hall, International Law 328-30 (8th ed., Higgins 1924); HigGrns \& Colombos, International Law of the Sea $\$ 274$ (2d ed., Colombos 1951); I Hym,

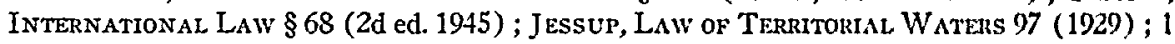
WESTLAKE, INTERNATIONAL LAW 171 (1910).

153. Hald, op. cit. supra note 152, at 323-24. See also 1 Hyve, op. cil. supra note 152, $\S 66$; JEssup, op. cit. supra note 152 , at 76,97 , arguing that since "the great principle of inviolability of national territory is qualified by the right of self-defense," a fortiori frec. dom of the seas is subject to the same qualification.

154. HaLL, op. cit. supra note 152, at 326-28; Kurlsrud, The Sitattre of the Danish Fleet, 1807, 32 Am. J. INT'L L. 280 (1938).

155. 1 OPPENHEIM-LAUTERPACHT 270-71.

156. Root, The Real Monroe Doctrine, 8 Am. J. Int' L. 427, 432 (1914).

157. See note 144 supra.

158. Boggs, Nationtal Clains in Adjacent Seas, 41 Geograp'utcal Rev. 185, $192-201$ (1951); text at notes $161,167,180$ infra.

159. See text at notes 115-19 supra. 
The impact of modern technology upon these demands for security is most dramatically illustrated by the claims recently asserted by the United States and Canada to exercise jurisdiction for security purposes in the airspace overlying vast areas of the Atlantic and Pacific Oceans. ${ }^{100}$ In 1950, the United States established certain "Air Defense Identification Zones" (ADIZ), defined as

"Air space . . . designated by the administrator of Civil Aeronautics within which the ready identification, location and control of aircraft is required in the interest of national security."1B1

Flight plans must be filed for both domestic and foreign flights before entering an $A D I Z,{ }^{162}$ and position reports must be made by foreign aircraft which are bound for the United States, upon entering an ADIZ or "when the aircraft is not less than one hour . . . cruising distance via the most direct route, from the United States."'63 Knowing or willful violators of these regulations are guilty of a misdemeanor, and upon conviction may be subjected to penalties ranging up to $\$ 10,000$ fine and one year's imprisonment. ${ }^{10 s}$ The Atlantic ADIZ extends seaward more than 250 miles, the Pacific ADIZ more than 300 miles, ${ }^{165}$ and in the case of a high-speed aircraft jurisdiction would be assumed at one hour's cruising distance, potentially 600 or more miles. ${ }^{168}$

In 1951, Canada promulgated similar regulations, providing for the creation of Canadian Air Defence Identification Zones extending seaward up to 180 miles, in which a similar type of jurisdiction over aircraft was asserted. 107 The Canadian regulations are less stringent than those of the United States in that the zones are smaller, and the regulations do not apply to aircraft flying at altitudes of less than 4000 feet. ${ }^{168}$ They are stricter, however, in that position reports must be made by foreign aircraft within defense zones whether or not they are bound for Canada or its territorial waters. ${ }^{160}$ Violation of the Canadian regulations renders the aircraft "liable to interflight interception by military interceptor aircraft."170 Neither the United States nor the Canadian claim has elicited any protest, so far as is known, and at least one commen-

160. The regime of the high seas is generally considered to apply to superjacent airspace For citations, see Briggs, The LAw of Natrons 323-26 (2d ed. 1952).

161. 14 C.F.R. $\$ 620.2$ (b) (Supp. 1954).

162. Id., $\$ 620.11$.

163. Id., $\$ 620.12(\mathrm{~b})(2)$. For the slightly more stringent position-reporting regulations to which domestic aircraft are subjected, see id., $\$ 620.12(a)$.

164. Id., $\$ 620.18$. For the statutory basis of these regulations, see the 1950 Amendment to the Civil Aeronautics Act of 193\$, at 64 ST.1T. \$25 (1950), 49 L.S.C. \$\$ 701-05 (1952).

165. 14 C.F.R. $\$ \$ 620.22(a)-(b)$ (Supp. 1954).

166. See note 163 sipra.

167. Canada Dep't of Traxspont, Rules for the Security Cuntrol of Am Traffic (NOTAMI 22, 1954).

168. Id., para.2.1.(a).

169. Id., para. 2.

170. Id., para. 2.10.1. 
tator has concluded with little difficulty that both sets of regulations are valid under international law. ${ }^{171}$

Among the claims asserted in the name of "security" are certain claims to exclusive use of high seas areas for peacetime naval and military exercises or maneuvers, sometimes implemented by a claim to civil or criminal jurisdiction for enforcement purposes. Although such claims may be traced indirectly to antiquity, ${ }^{172}$ their legality has apparently seldom been questioned or even discussed. It is this class of claims to which generically the claim made by the United States in connection with its thermonuclear bomb tests belongs.

It has already been observed that the activities of ships themselves sometimes constitute a noticeable interference with the navigation of others, particularly in the case of trawlers, dredges, cableships, and naval vessels in formation or engaged in maneuvers, and that such vessels can get sea room by making appropriate signals. ${ }^{173}$ With the increased range of naval guns and coastal artillery, and the appearance of increasingly dangerous devices of naval warfare, states with extensive naval forces found it necessary to institutionalize some of their peacetime defensive activities in order to minimize conflict between those activities and commercial navigation and fishing. Exercises involving the use of modern weapons could not be conducted with safety except in relatively unfrequented areas, and, moreover, mariners preferred to avoid exercise areas altogether rather than to be delayed and endangered by unexpected encounters. New means of communication made it possible to supplement, if not to displace visual signalling as a means of reducing interference between navigation and dangerous defensive activities.

171. Martial, State Control of the Air Space over the Territorial Sca and the Contiguous Zone, 30 CAN. B. Rev. 245 (1952).

172. From the earliest times, various commentators have found it necessary to accord special consideration to the status of war fleets in peace. Grotius contended that "sovereignty," as opposed to "ownership" over a sea area could be acquired by stationing a flect there. 2 Grotius, De Jure Belli ac Pacis 214 (Kelsey trans. 1925). See also 1 PinthitMORE, Commentaries upon International Law 290-91 (3d ed. 1879): "The portion of sea actually occupied by a fleet riding at anchor is within the dominion of the nation to which the fleet belongs, so long as it remains there; that is, for all purposes of juriscliction over persons within the limits of the space so occupied." For criticism of an incorrect paraphrase of the passage quoted, see 1. OPPENHEIM-LAUTERPACHT 540 n.4.

While claims to "sovereignty" over sea areas have never in fact been made on the basis of occupation by naval forces, several authorities have asserted that naval vessels in formation or engaged in maneuvers should be accorded the right of way at sea under all circumstances, 1 Gidel, Droit Internatignal Public de la Mer, 360 ; de Ryckere, Droir Maritine Belge 509 (1913), and the "Special Circumstances" and "General Precautionary" rules have occasionally been so interpreted. See the Sanspareil [1900] P. 267; Gkirrw, Collisions $\$ 230$ (1949) ; Hilbert, International Rules of the Rond at Sea 130 (1938). The British Admiralty has categorically asserted that it is the duty of a single vessel to keep out of the way of a squadron or convoy. Admiralty Notices to Mariners, Jatn. 1, 1954, pp. $39-40$ (weekly ed.).

173. See text at note 77 supra. 
Naval powers therefore began the practice of conducting their more dangerous maneuvers and defensive activities in circumscribed areas selected with a view to creating the least possible interference with navigation and fishing. Mariners throughout the world were advised, through national hydrographic offices and other channels of information relating to navigation, ${ }^{174}$ that designated areas would be unsafe for navigation either indefinitely or at certain times. The United States has established well over 400 such areas, ranging in size from less than a square mile to the vast area surrounding Bikini and Eniwetok Atolls, and in duration from a period of a few hours to many years. ${ }^{175}$ Other naval powers, including the United Kingdom, Canada, Australia, and the Soviet Union, have engaged in the same practice for similar purposes. ${ }^{176}$ Ordinarily, no claim is made to enforce warning areas by means of formal sanctions, and the normal responsibility for taking reasonable measures at the scene to avoid accidents is considered to rest with the authorities using the areas for dangerous operations. ${ }^{177}$ Some danger areas are, however,

174. As every mariner knows, a network of national and international urganizations cooperate to make available to mariners throughout the world infurmatiun relating to hazards to navigation, such as warning and danger areas, wrecks, missing or inuperative lights and buoys, oil-well structures, minefields, blochiades, recently discuvercel reeis, and so on. See generally Admiralty Notices to MIariners, supra note 172, at 50-52, 155; U.S. Navy Hydrographic Office, Notice to Mariners (Special) 25-42 (Jan. 1, 1954). Sume forty-one nations and the International Hydrographie Office at Monte Carlu, MI nacu, cuoperate in the distribution of notices to mariners. Id. at 30. For leseription of the services provided by the U.S. Navy Hydrographic Office, see its INFumatos o: Hymcomapulc Office Charts \& Perlicitions (H.O. Circular No. 3, 1954).

175. N.Y. Times, April 1, 1954, p. 20, col. 2. For numerous examples, see any issue of U.S. Navy Hydrographic Office, Notice to Mariners (weekly ed.); U.S. Dep't of Co:sArerce, Restricted, Daxger aNd Axchorige Areas 94, 104, 118, 130, 134, 149, 156, 201 (Ser. No. 693, 1947) ; Admiralty Notices to Mariners, supra note 172, at 37.

176. See, e.g., Admiralty Notices to Miriners, supra note 172, at 37, 39-40, 67 (United Kingdom), 178 (Yugoslavia, Greece), 187 (Australia), 190 (Venezuela, United States); U.S. Dep't of Conmerce, op. cit. sitpra note 175, at 200, 201 (Canads); Soviet Nitices to Mariners, Nos. 717, 935, 936 (1947), 1121, 2446 (1954) (translations on file in Yale Law Library). See also text at notes $180-S 4$ infra. For a chart depicting a zone of approsinately 50,000 square miles, estending from Florida out into the Atlantic and acruss the Bahamas. used jointly by the United States and Britain for the testing of long-range guidsd missiles, see Gt. Brit. Foreign OfF. Treati Ser. No. 74, at 14 (1950).

It is the usual international practice for nations issuing navigation nutices tu supply: copies to other maritime nations, which reprint them in their own languages for the information of their mariners. Examples of recent Soviet practice are few, since the Swiet Union stopped supplying the United States with Notices to Mariners in 1947, giving nu, reason, and then, in 1954, again giving no reason, suddenly resumed suprlying them. See Admiralty Notices to Mariners, supra note 172, at 175.

177. U.S. Hydrographic Office, Notice to Mariners (special) 15-16 (Jan. 1, 1954); Admiralty Notices to Mariners, supra note 172, at 37 .

It seems likely that the practice of creating warning areas by dissemination of advance notice by radio and printed memoranda evolved naturally from visual signalling, and that if it had ever been questioned, states would have defended it as an exercise of "freelum of the seas." Thus, states' attempts to prevent foreign nasal furces irom engaging in gunnery practice outside territorial waters, but within range of shore, have lieen defended, in 
announced in terms which make clear that the authorities using them are expected to enforce observance. ${ }^{\mathbf{1 7 8}}$

In rare instances, criminal penalties are provided for unauthorized intrusions. ${ }^{179}$ In the Defence (Special Undertakings) Act of 1952, ${ }^{180}$ the Commonwealth of Australia created a prohibited area of more than 6000 square miles, most of it high seas, ${ }^{181}$ surrounding one of the Monte Bello Islands in western Australia, where atomic tests have been conducted by the United Kingdom. ${ }^{182}$ Persons entering the area without permission are made subject to penalties ranging up to seven years' imprisonment. ${ }^{183}$ The Act empowers the Minister to declare other restricted areas whenever it is "necessary so to do for the protection of a special defence undertaking," defined as any work or undertaking carried on within or without Australia, relating to the defense of itself, "some other part of the Queen's dominions or of some other country associated with Australia in resisting or preparing to resist international aggression." 184 No protest by any nation against the Act has been reported.

The especially privileged status in world prescription of claims to exercise authority and control upon the high seas for purposes of security, even in time of "peace," is particularly confirmed by the practice of Great Britain. A1though that nation is usually considered to have altered its previous attitude and is counted among the few states which oppose claims to contiguous zones generally, it has followed a consistent course of approving the widest freedom of decision for itself and for other states in matters affecting defense and security. ${ }^{185}$ This attitude, shared as we have seen by other states eqtally

effect, as reasonable infringements of freedom of the seas. Letter from Secretary of State Bayard to Secretary of the Treasury Manning, May 28, 1886, in 1 Wilakton, Dialst of International Law 107-09 (2d ed. 1887) ; Harvard Research Draft on Terrutorial WATERs 335-36 (1929). Moreover, although it seems certain that every state with naval forces or even shore batteries has always claimed the right to use the seas outside territorial waters for dangerous defensive activities in time of peace, only Belgitum thought it necessary to mention this claim in its reply to the Preparatory Committee for the 1930 Codification Conference. See 2 Preparatory Commitre of the Conferenct mor tile: Codification of International Law, Bases of Discussion 120 (League of Nations Pub. No. C.74.M.39.1929.V).

178. "Restricted," "closed," and "prohibited" areas are announced in stuch terms, sec, e.g., U.S. Dep't of Conrmerce, op. cit. silpra note 175, at 95; Admiralty Notices to Mariners, supra note 172, at 190; U.S. Navy Hydrographic Office, Notice to Mariners, pt. 2, No. 24, para. 3168 (June 13,1953), and are apparently differentiated carefully from "danger," "warning," and "caution" areas.

179. So far as is known, the United States has never laid claim to civil or criminal jurisdiction to enforce exclusion from any warning area outside territorial waters. For practice as to peacetime defensive sea areas within territorial waters, see note 100 supra; cf. text at notes 160-66 supra.

180. 50 Commonivealth Acts 64 (1952).

181. Goldie, Anstralia's Continental Shelf, 3 INT't \& Comp. L.@. 535, 550 11.43 (1954).

182. N.Y. Times, Oct. 15, 1953, p. 3, col. 5.

183. 50 Conmonwealtr Acts 66, 67 (1952).

184. Id. at 65,67 .

185. See notes 150-52 supra and accompanying text. Professor Smith, often a clear 
solicitous of "freedom of the seas," is eloquently expressed in the British Territorial Waters Jurisdiction Act of 1878, still in effect:

"the rightful jurisdiction of Her Majesty . . extends and has always extended over the open sea adjacent to the coasts of the Lnited Kingdom and of all other parts of Her Majesty's dominions, to such a distance as is necessary for the defense and security of such dominions."180

This traditional feature of British policy is most recently evidenced by her obvious acquiescence in the Australian legislation enacted to facilitate Britain's own atomic tests, and her apparent acquiescence in United States and Canadian air defense regulations.

In time of acknowledged war "freedom of the seas" is, of course, subject to exceptions so numerous and substantial as virtually to overwhelm the principle itself. ${ }^{187}$ Belligerents are authorized to conduct hostilities against each other anywhere upon the oceans of the world, save in the territorial seas or protective zones of neutrals, ${ }^{188}$ and they have commonly rendered vast stretches of the ocean unsafe for commercial navigation, paying but scant attention to the claims of non-participants for neutrality zones. ${ }^{159}$ Even under the older doctrines of contraband, unneutral service, blockade, ultimate destination, war zones, and reprisals, enforced by the procedures of visit and search, and capture, a belligerent who has the effective power is authorized

spokesman of official British policy, has said: "Nearly a century has nuw y'asced since the unsatisfactory dispute with Spain [over British Hovering Acts] was allowcd $t$, die wut, and since then the government of Great Britain has shown an increasing reluctance to resist actively such claims by other states as can be justified on the principle of seli-defenะe." Sisiru, The Law and Custoar of the Sea 21 (2d ed. 1950). See also Martial, Statc Conirol of the Air Space over the Territorial Sea and the Contiguous Zone, 30 Can. B. Rev. 245, 263 (1952). For the opinion that Britain is opposed to contiguous zones only "to sume extent," see Lauterpacht, Sovereignty ozer Submarine Areas, 27 Bart. Y.B. Ist'L L. 370, 20 is (1950), citing Croft v. Dunphy, [1933] A.C. 156.

186. 41-42 VICT. c. 73 (1878). Compare the statement by President Roosevelt that uur territorial waters extend "as far as our interests require," quoted in Mastersun, Thic Hemisphere Zone of Security and the Law, 26 A.B.A.J. 860, 861-62 (1940).

187. Before turning from the subject of the law of the sea in time of "peace," it seams appropriate to mention, for purposes of completeness, the institution of "pacific blaclade," another practice which, before the advent of the United Nations Charter, was recugnized as lawful by many, and which enabled nation-states to control large areas of high seas in time of "peace" on occasion for no better purpuse than the collection of delits. See generally Grob, The Rejativity of War and Peice (1949); Hrwdararsir, Force ix Peice. (1933); Hogan, Pactfic Blocrade (1908); Giraud, Memorandum on Pacific Rloclade, League of Natrons Off. J., Sth year SH1 (1927): Washburn, The Legality of Pacific Blockade, 21 Coluas. L. Rev. 55, 227, 412 (1921).

18S. Huggins \& Colongos, Internatronal Law of tue Sei c. 13 (2d ed, Colomlus 1951) ; 2 Opfenhems-Lauterpacht $\$ 181$ : Smith, The LaW and Custos of the SEs 148 (2d ed. 1950).

189. See, e.g., Masterson, The Hemisphere Zone of Security and the Lan', 26 A.B.A.J. 860,863 (1940). For excellent illustration of the normative-ambiguity in "ircedom of the seas" in this context, see Reppy, The Grotian Dactrine of Frecdom of the Scas Rcapfraisad, 19 FORD. L. REv. 243, 283 (1950). 
for all practical purposes to close the high seas to enemy-neutral commerce. 110 $^{110}$ When policing procedures are supplemented not only by the more recent technology of aircraft, submarines, and mines, but also by the new administrative practices of navicerts, rationing of neutrals, ship warrants, bunker control, insurance and credit control, and black listing, ${ }^{101}$ control may be made even more complete, and the legal policy question becomes not merely whether belligerents may close the oceans to enemy-neutral traffic but also whether they may not order the observance of certain measures even within the territorial boundaries of non-participants. In such a context, freedom of the seas, even in its most rational sense, recedes almost completely in world prescription before certain other values summed up in the military necessities of bodies politic struggling for survival.

\section{The Hydrogen Bomb Tests As Reasonable Measures for Security}

The claim of the United States which is under discussion may be described factually as a claim to use territory (Bikini and Eniwetok Atolls) over which it has jurisdiction, for the purpose of conducting tests of thermonuclear weapons, a use which has the effect of excluding others temporarily from large surrounding areas of the high seas. The United States has established warning zones from time to time which serve to inform mariners of the extent of the area in which danger exists. ${ }^{102}$ No authority to enforce observance of warning zones has been asserted, but as a practical matter observance follows because of the danger from the tests themselves. ${ }^{103}$

The extent to which the bomb tests have actually interfered with commercial navigation, in spite of the size of the area affected, is virtually nil. No commercial maritime route crosses any part of the warning zones which have been established, and the nearest sea route of any importance, that followed by ships plying between Honolulu and Manila, passes some 165 miles north of the outer edge of the largest warning zone. ${ }^{104}$ The next nearest trade route,

190. See, generally, Higgins \& Colonibos, op. cit. supra note 18\&, cc. 14, 16-18, 20 ; SMITH, op. cit. supra note 188, cc. 8-14.

191. For description of modern techniques of controlling enemy-neutral commerce in time of war, see, generally, 1 Medicotit, The Economic Blockade (1952); Stone, Legal Controls of International Conflict pts. 3, 4 (1954); Wu, Economic Wantarke (1952). For outstanding analysis, see Felictano, Legal Regulation of Transmattonal Coercion: Studies in the LaW of War cc. 2, 3 (unpublished thesis in Yale Law Library 1954).

192. See text at notes 19-24 supra.

193. Thus far, authority to exclude others has been asserted only with respect to Bikini and Eniwetok and their territorial waters. See Notices eited notes 20-23 supra. However, at the time of the first atomic bomb tests at Bikini in 1946, the late Admiral Blandy asserted that any intruders in the immediate test area would be ejected by force if necessary. N.Y. Times, June 26, 1946, p. 7, col. 5.

194. U.S. Navy Hydrographic Office, Track Chart of the World (No. 1262, 27th ed. 1943) (excerpt reproduced opposite p. 650 supra) ; U.S. Maritime Comm'N, Essentiat Foreign Trane Routes 17, 28 (1949). See also Letter from Serge G. Koushnareff, Deputy 
Honolulu to the Torres Strait, lies 420 miles southeast of the warning zone and some 660 miles from Bikini. ${ }^{195}$ One commercial air route, that between Wake Island and Guam, was deflected northward by the largest zone, making it necessary for two to three flights weekly to follow a route fifty miles longer than usual during the fifty-seven days that the zone was in effect. ${ }^{100}$ Analysis of maritime routes indicates not only that interference with navigation caused by the zones was slight, but that few if any sea areas of comparable size in the world are less essential to international navigation, with the possible exceptiun of the Antarctic. 197

Furthermore, the amount of interference with fishing caused by the existence of the warning zones appears to have been slight. Fishing for tuna, slipijack, and bonito has been carried on by the Japanese in waters which were within the warning zones, but the minor character of the interference with fishing attributable to the zones is indicated by the fact that in prewar years the catch from the entire area of the Japanese Mandated Islands, of which the zones covered only a small part, amounted to far less than one per cent in value of the annual fisheries production of the Japanese Empire. ${ }^{108}$ The annual tuna catch from the waters within the largest warning zone $(400,000$ square

Director, Transportation and Utilities Div., Eureau of Foreign Cummerce, C.S. Depit ui Commerce, to the Yale Law Journal, Dec. 30, 1954, on file in Yale Law Library.

195. Track Chart of the World, supra note 194. No commercial shipging lines vinit the Trust Territory, U.N. Trusteeship Council Visiting Mission, Report on the Trust Territory of the Pacific Islands 17-1S (Doc. No. T/1077) (1953), and the bulk of interisland transportation facilities in the Islands is owned or operated by the Administering Authority. Ibid.; U.S. DeP'T of INTERIOR, 1952-53 REPORT ON THE AusINISTRITIO: of THE Trust TerRitory of THe Pacific Islands $43-44$ (1954).

196. Letter from J. B. Cooke, Jr., Ass't Division Operations Mlanager, Pacific-Alasla Division, Pan-American World Airways System, San Francisco, Calif, to the Yale Law" Journal, Feb. 8, 1955, on file in Yale Law Library.

197. See Track Chart of the World, supra note 194.

198. U.S. Dep'T of Interior, Japanese Fisheries Prodiction 1908-1946, at 3, 20 (Fishery Leaflet 279, 1948) (reproduction of Report No. 95, Natural Resources Sectiun, General Headquarters, Supreme Commander Allied Powers, Japan). MLinimum fichery production of Japan during 1931-1938 was 4,900,000 metric tons. Id. at 3. Mraximum production of the Japanese Mandated Islands, occurring in 1937, was 3,852 metric tons. While Japan has lost a number of fisheries since World War II, so that the island fisheries now may be relatively more important, they would have had to increase more than ten-fold in importance to amount to $1 \%$ of total production.

Moreover, the warnings in effect from 1948 to 1954 affected a mere $1.6 \%^{\circ}$ of the Bonin and Mandated Regions Area. See U.S. Dep't of Irterior, The Japanese TUNA FismerIEs 11 (Fishery Leaflet 297, 1948). The largest warning zone, in effect for 57 days in 1954 , see note 23 supra, covered approximately $7 C^{\prime} C$ of the Area. Ibid.

Fishing in the Territory of the Pacific Islands is apparently subject to hazards other than occasional radioactivity. See U.S. Dep't of Ixterior, Sunter of tue Fisneries of the Foraser Japanese Mlandated Islands 59-60, 79-81 (Fishery Leaflet 273, 1947), listing 44 varieties of poisonous fish to be found in the islands. See also statement by Admiral Strauss in N.Y. Times, April 1, 1954, p. 17, col. 1, to the effect that all fish eaught in the Bikini area are inedible at some seasons of the year due to the prevalence in the water wi certain poisonous micro-organisms on which they feed. 
miles), in effect for fifty-seven days, amounted to a fraction of the seven per cent of Japanese tuna production attributable to the entire Bonin and Mandated Regions area (approximately 2.5 million square miles). ${ }^{100}$ Moreover, since tuna are found throughout the North Pacific, ${ }^{200}$ it seems probable that fishing could have been deflected to areas adjacent to the zone with little if any loss in yield.

Plainly no existing prescriptions in the regime of the high seas are literally applicable to the unique problem presented by the tests. The United States claim bears no similarity whatever to those which, historically, "freedom of the seas" was intended to combat.201 Others are not excluded from the area affected in order to enable the United States to grant fishing monopolies to its nationals or to pursue the commercial aggrandizement of the United States in any way. ${ }^{202}$ It is apparent, also, that the claim of the United States offers no serious interference with the policies of promoting commercial navigation and fishing which underlie "freedom of the seas." Moreover, the claim does not offend against the subordinate policies against international friction which are involved in claims to exercise police powers on the high seas. No ships are seized or condemned, nor is civil or criminal jurisdiction of any kind asserted.

What is relevant, and can be applied without irrational extrapolation, to this new problem from prior prescriptions in the regime of the high seas is the test of reasonableness which underlies them all-the test by which the decision-makers of the world community have consistently during modern times decided between claims to navigation and fishing and all that great variety of claims, recounted above, which may interfere with navigation and fishing, and ranging, as we have seen, through all the labels of "territorial sea," "contiguous zones," "piracy," "self-defense," "continental shelf," and so on, even to "freedom of the seas" itself. ${ }^{203}$ Because of their support of this

199. U.S. Dep't of INTERIoR, The Japanese Tuna Fisheries 11 (Fishery Leaflet 297, 1948).

200. Allen, Fishery Geography of the North Pacific Ocean, 43 Geornirnicul Rev. 558,561 (1953).

201. See notes 83-84 supra and accompanying text.

202. It may require explicit statement that Dr. Margolis' separate exposition of "the law of fisheries," Margolis, pp. 640-41, adds no new authoritative prescription or policy to those elsewhere expounded under the headings of "freedom of the seas" and "pollution." The different expositions refer to the same facts, the same legal technicalities, and the same policies. Lack of homogeneity in argument should not be taken for multiplicity it relevant prescription.

The concept of "abuse of rights," in particular, is merely an impressive-appearing circumlocution, fancied in some circles, for unreasonable behavior.

203. Our emphasis is of course upon the reasonableness test which underlies specific applications of the "freedom of the seas" principle. As has been seen, text at notes 172-77 supra, the right to use the seas for such space-consuming activities as trawling, dredging. and conducting dangerous maneuvers and peacetime defensive activities, has always been claimed under "freedom of the seas," at least where no civil or criminal jurisdiction to enforce exclusion has been asserted. One might, however, derive a similar conclusion cven 
test, all the decisions sustaining claims which interfere with navigation and fishing, whether for contiguous or non-contiguous uses, may be regarded as relevant authority for appraising the claim of the United States. The claim of the United States must enjoy, of course, whatever contribution to reasonableness the factor of contiguity may make, ${ }^{204}$ since the United States has jurisdiction not only over the land areas within the warning zones, but also over all land areas whatsoever for nearly a thousand miles.00 Beyond propinquity to controlled shores, the United States may, however, point to many

from dogmatic exposition of the principle. If "freedom of the seas" is an ahsolute, as Margolis, p. 634, says it is, it may therefore reasnnably be asked why the seas are not as "free" for nuclear weapons tests conducted in the interests of survival of the llest, as they are for navigation and fishing.

204. It is worthy of note that contiguity has never been a particularly important facti, in claims to conduct dangerous maneuvers or exercises at sea, perinas for the reasun that non-contiguous warning areas are often less of an interference with international navigation and fishing than zones near the claimant nation's shores would be. For examples ui totally non-contiguous warning zones, see U.S. Hydrographic Office, Nutise to Mariners, pt. 1, No. 1, para. 33 (Jan. 1, 1955). Prescriptions relating tu piracy and self-defense, similarly, have not depended on contiguity, but authorize unilateral action on the high seas wherever and whenever it may be necessary. See notes 150-53 sufra.

The factor of propinquity, with respect to any type of claim, is liut a plyysisal isctur important for its bearing upon the reasonableness of a particular claim. The test of reasenableness is not determined by this factor alone, or limited to contexts in which it is present. In contexts where it is not present, other factors may perform a cumparable function in offering indices of reasonableness. Contiguity may be expected to lose much of the importance which has been attributed to it as technology inexorably pushes national interests outward, and demands uses of the seas yet unforeseen. For suggestion of gossible future developments, see Smith \& Chapin, The SUn, the SEI, and Tosorrow (1954).

A concept which already bridges whatever gap there may be between cuntiguus and non-contiguous claims is the doctrine of "hot pursuit." This highly interesting ductrine is the product of interaction between the claims of nation-states to malse effective their protective jurisdiction in marginal seas, and other states' demands for reasonable limitation of such claims. See Dickinson, Jurisdiction at the Maritime Fronticr, $40 \mathrm{Harv}$. L. RE. 1, 21 (1926). "Hot pursuit" enables states to seize and condemn ships anywhere on the seas, so long as the seizure is made in the course of an immediate and uninterruptcd pursuit which began in adjacent seas. See, generally, Hugonss \& CoLonsros, Tue Irternasto:isl LAW of the Sea 108-11 (2d ed, Colombos 1951); Sarte, The Law and Custos of the SEA 55-56, 114 (2d ed. 1950) ; Briggs, The LAW of Namows 34S, 385-S8 (2d ed. 1952).

205. The nearest land not under U.S. jurisdiction is Nauru, 750 miles south of Bilini, a trust territory administered by Australia. See U.N. Doc. No. A/402 (1947).

Having full powers of government over the areas, the United States has, of course, fur all practical purposes the same powers over sea areas contiguous to Bilini and Eniwetok that it would have over seas contiguous to its own continental shores. See Harvaro RE-

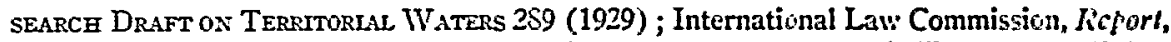
U.N. Generai Assendbly Off. Rec., 9th Sess., Supp. No. 9, at 15 (Doe. No. A/2693) (1954) ; id., Sth Sess., Supp. No. 9, at 19 (Doc. No. A/2456) (1953). For ajproval of an exercise of arrest and seizure powers by a mandatory state at a distance of 100 miles seaward from the coast of the mandate, see Naim Mfolvan v. Attorney-Gencral fur Palestine, [194\$] A.C. 351, 369; Note, 10 CAars. L.J. 268 (1949); Note, 24 N.Y.U.L.Q. 439 (1949). For further elaboration of the powers of the United States as Administering Authority of the Territory of the Pacific Islands, see text at notes 245-85 infra. 
other factors as indices of the reasonableness of its claim, factors comparable to those which prior decision-makers have invoked to sustain so great a variety of claims to non-contiguous uses. The factors most relevant for appraising the United States claim are that it is for a purpose much honored in world prescription, that it asserts the least possible degree of authority necessary to the achievement of its purpose, that it is limited both in area and in duration to the minimum consistent with its purpose, that the area which it affects is of relatively slight importance to international trade and fishing, and that it is asserted in a context of crisis which makes its purpose of para* mount importance to all who value a free world society.

The claim of the United States is in substance a claim to prepare for selfdefense. It is not, as commonly in self-defense, a claim to respond with force to an attack; it is no claim to invade territory or to sink fleets in anticipation of attack or to take any of the other measures of drastic interference with others commonly subsumed under self-defense. It is, however, a claim to take certain preparatory measures under conditions comparable to those traditionally held to justify measures in self-defense. It is a claim to take certain actions in contiguous zones and upon the high seas, with the minimum possible interference with others, under conditions of high necessity. The conditions of this grave necessity and the absence of reasonable alternatives are familiar knowledge. The contemporary development of instruments of destruction makes it possible for a war-bent nation-state utterly to destroy an opponent and perhaps much of the world. It has not been possible to establish, under the United Nations, commitments and procedures of global scope which offer reasonable assurance against aggression. As expectations of imminent violence in the world arena have become ever more realistic and intense, many of the nations of the free world have organized themselves, under appropriate provisions of the U.N. Charter, into regional groupings for their more effective self-defense. ${ }^{206}$ The United States has undertaken its program of atomic and thermonuclear weapons clevelopment to ensure that these coalitions of free nations are not lacking in the retaliatory power which may deter aggression, or in the weapons of self-defense if deterrence fails. ${ }^{207}$

Even prior to the bipolarization of the world and the development of nuclear weapons, it was generally agreed that a nation-state could, under the necessities of self-defense, take the most drastic measures in interference with what would otherwise have been the rights of others. Some of the historic examples of the exercise of this right of self-defense have been recounted above and others may be found in all the texts. So fundamental is the

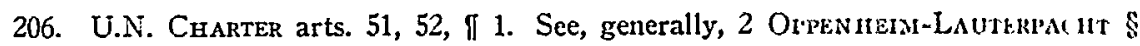
52aa; recent authorities cited note 145 supra.

207. The tests have in addition a purely defensive utility, wholly anart from deterrence and retaliation. Those who are inclined to doubt this defensive utility of the tests may with profit attempt to estimate the number of lives which would be saved, in the event of an attack upon the United States or another western nation, by ku'wledge of the magnitude and character of radioactive fallout gained in the tests of 1954, now being disscminated by civil defense organizations. 
underlying policy, in a world without adequate centralized authority for the maintenance of public order, that an express exception for self-defense is an integral part of the prohibition of violence which appears in the United Nations Charter. ${ }^{208}$ Exercised in the first instance by the nation-state whose existence is threatened, but subjected also to review for reasonableness by external decision-makers, this right is no nullification of world order but one of the few remaining instruments by which world order may be sought. ${ }^{208}$ If, therefore, the present legal organization of the world and posture of world affairs put so high a premium upon self-defense, with authorization of potentially the most drastic interferences with others, it cannot, we believe, be reasonably concluded that it is unreasonable for the United States to engage in temporary and limited interferences with navigation and fishing upon the high seas in preparation for defense of itself, its allies, and all the values which they cherish.

The attack upon the legality of the United States claim to conduct the Pacific tests is made, perhaps it should be added, under the beneficent assumption that the claim is made "in time of peace."210 It is, however, no longer original to suggest that "peace" is scarcely an accurate description of the contemporary relation between the free and the totalitarian worlds. Indeed, as expectations of violence continue to increase, and as the world approaches perilously near the polar extreme of war, the literature of international law reflects increasing dissatisfaction with the traditional war-peace dichotomy, and its unrealistic, mutually exclusive world prescriptions. ${ }^{211}$ While there has been little overt recognition, in the formulation of prescriptions, of the erosion

208. U.N. Charter art. 51.

209. The indispensable complementarity in world prescription of concepts of unlaw iul riolence, such as "aggression," and of self-defense sometimes eseapes commentators. See, for discussion, PoAspe, Aggressive War 55 (1953) ; Stone, Leg.ll Controls of In:tansiaTIONAL CONFLICT 242, 330 (1954).

It must be either obscurity with respect to this fundamental characteristic of legal prescription or else peculiar French reaction to historic, inordinate German demands that explains Gidel's surprising reservations, in his otherwise brilliant study, cuncerning the role of "self-defense" in authorizing claims to control upon the high seas. See, Gidel, IIcmorandum 8 . The external decision-makers who pass upon the reasonableness of claims need yield no more to arbitrary and dogmatic absolutism in the name of "seli-defense" than in the name of unlawful violence. The one concept is as amenable to ratiunal applieation as is the other. It surpasses understanding, furthermore, why self-defense should be regarded as so important in the "territorial sea" and suddenly cease to be important upon the passing of some imaginary line in the water.

210. Margolis, p. 635.

211. The most cited studies are Grob, The Relativity of War and Pesce (1949), and Eagleton, The Attempt to Define War, Ixt' Coxcilmation No. 291 (1933). See also Stone, Legal Controls of International Conflitt 312 (1954); 1 Whight, A Stctiy of WAR 10 (1942); Borchard, War and Peace, 27 Axr. J. INT'L L. 114 (1933); Jessup, Should International Law Recognize an Intermediate Status Between Peace and II 'ar', is id. 98 (1954); Jessup, Intermediacy, 23 NoRDIsK Tinsskrift föR Isternatron:ule Ret 16 (1953) ; MeNair, The Legal Meaning of War and the Relation of II"ar to Refrisuls, 11 Trans. Grotrus Soc'y 29 (1926) ; Ronan, English and Anerican Courts and the Dejinitiun: 
of this misleading dichotomy, the more flexible areas of customary law have long since responded to the nuances of change in factual context. In the determinations of reasonableness which are necessary throughout the law of the sea, decision-makers have simply accorded progressively greater deference to the need of individual states to take unilateral measures for their security. ${ }^{212}$ A similar realism might be invoked to reenforce the conclusion that the claim of the United States to conduct hydrogen bomb tests is, under contemporary conditions, a reasonable assertion which contravenes no prescription or policy of the international law of the sea. ${ }^{213}$

It is obviously not necessary, in order to establish the lawfulness of the hydrogen bomb tests, to establish the further lawfulness of the use of such bombs against any enemy under all conceivable circumstances in any possible futture war. Since, however, various broad assertions have been made that any use of such bombs would or might be illegal under the law of war, ${ }^{214}$ a few considerations may be noted.

It would, in the first place and most relevantly, seem clear that any prior use of such weapons by an enemy would immediately authorize the United States to use the same weapons in reprisal. ${ }^{215}$ The whole purpose of the law of reprisal in relation to the prohibitions of the law of war, like that of selfdefense in relation to aggression, is to permit the use of what would otherwise be lawless violence as a sanction against lawless violence. ${ }^{210}$

of War, 31 Am. J. INT'L L. 642 (1937); Schwarzenberger, Ius Pacis ac Bclli, 37 id. 460 (1.943) ; Tucker, The Interpretation of War under Present International Laze, 4 INT'L L.Q. 11 (1951). For the mode of analysis we recommend, see McDougal, Peacc and War: Factual Continumu with Multiple Legal Consequences, 49 AM. J. INT'L L. 63 (1955).

212. See text at notes $145-91$ supra.

213. It is perhaps worth mentioning that the neat "legal" dilemma, set up in Margolis, p. 636, that "the greater the degree of precaution" the United States takes to warn people out of the danger zones, "the greater the interference with freedom of navigation on the high seas," assumes his answer to the very question in issue: that the warning zontes established by the United States are unlawful. In popular parlance this is known as levitation by one's own bootstraps.

214. See Margolis, p. 639 n.59, and authorities cited. See also The Present Stale of International Law, Address by W. Harvey Moore, International Law Association, Edinburgh Conference, 1954, p. 9; Spaigut, Air Power and War Riguts 274 (3d ed. 1947); Sack, A.B.C.-Atomic, Biological, Chemical Warfare in International Law, 10 LAw. Guiln Rev. 161 (1950). Discussion of pros and cons with references is offered in STONE, LEGAL. Controls of International. CONFLict 342 (1954) and 2 OpPEn hein-LAUTERi'ACHT 34\%. 352.

215. Id. at 351.

216. Albrecht, War Reprisals in the War Crimes Trials and in the Geneza Conventions of 1949,47 AM. J. INT'L L. 590 (1953).

Suggestions occasionally found in the literature that the cloctrine of reprisals is a negation, rather than a sanction of law reflect again a lack of understanding both of the complementarity of prescription in the whole law of war and of the indispensability of selfhelp sanctions in a decentralized world order. McDougal, supra note 211, passim. 
It would, in the second place and with scarcely less relevance, appear most difficult for a contemporary decision-maker to achieve a complete prohibition against the prior use of such weapons by generalization from prescriptions created with respect to very different weapons in a very different world. There is no express prohibition of the use of nuclear weapons in either customary or conventional international law, and the argument for prohibition is derived by "analogy" from prescriptions with respect to poisonous gas and

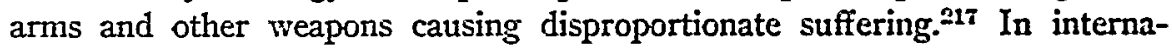
tional as in municipal law, however, analogies in prescription and decision are relevant only for the policies which infuse them.

The fundamental policy which underlies the various analogies invoked with respect to nuclear weapons, as well as the prohibitions with respect to all other weapons and indeed the law of war generally, is the minimum destruction of values-that is, the balancing of "military necessity" for "legitimate objectives" against "humanitarianism" and the disproportionate or irrelevant destruction of values. ${ }^{218}$ The Achilles heel in this policy is, in common knowledge, that the decision-makers of the world community have never been able to become very precise about the "legitimate objectives" of violence or, hence, about the degree of destruction permissible under "military necessity"; ;10 and in the contemporary bipolar world, with totalitarians and proponents of the dignity of man confronting each other in mortal struggle, agreement upon these fundamentals seems less likely than ever. It is not necessarily a mark of moral superiority, but perhaps rather of suicidal arrogance, to suggest that no possible uses of the hydrogen bomb could conceivably be within the scope of "military necessity" for objectives legitimate by standards of respect for human dignity.220 It would appear the most rational course to withhold

21\%. For citations see note 214 sts sra.

218. In making this generalization and in this whole analysis of the lawiulness of pis-

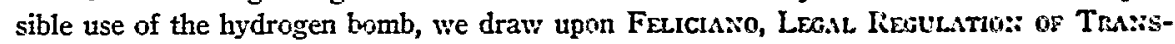
wattonaz Cogrcion: Stunes in the Law of War (unpublished thesis in lale Law Library 1954).

The fundamental policy is easily idientifiable in the decisions and literature of the law of war. See Phillips, Air IVarjare and the Law, 21 Geo. W.1sn. L. REx. 311, 395 (1953); Lauterpacht, The Problem of the Rezision of the Las' of I" "ar, 29 ERIT. Y.B. I:T'L L. 330

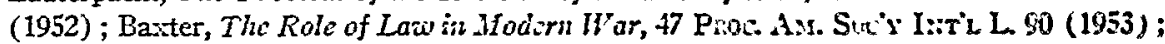
Kunz, The Chaotic Status of the Lau's of I' ar and the Uracnt Necessity for thcir Recision, 45 Axr. J. InT'L L. 37 (1951).

219. The basic conflict about "legitimate objectives" of violence is well illustrated in the continuing debate about the definition of aggression. See Posspe, Acgressive War a:: InteRnational CRIMe 39 et seq. (1953): STONe, suira note 214, at 330; International Law Commission, Report of the Special Committec on the Question of Defining Aunressiun, U.N. Gexeral Assemrey Off. Rec, 9th Sess., Supp. No. 11 (Due Nu. A/Z638) (1954).

The vagaries that ensue with respect to "military necessity" may be sampled in 3 Dunbar, 1rilitary Necessity in War Crimes Trials, 39 Brir. Y.E. InT'L L. 442 (1952); Uuwney, The Law of War and Military Necessity, 47 AMr. J. InT'L L. 251 (1953); 1 Sro:is, sugrus

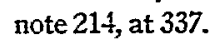

220. Note the careful outlining of relevant considerations in Stimson, The Decision 
blanket judgment and to appraise each specific use of nuclear weapons, as most other weapons and destructive practices are appraised, in the total context of such specific use.

It is not the particular physical modality of destruction that is relevant to law and policy but rather the purposes and the effects of the destruction and the relation of these purposes and effects to the values of a free world society. ${ }^{221}$ Certainly proponents of the dignity of man cannot rationally expect, by writing self-inhibiting meanings into the concepts of "military necessity," "legitimate objectives," and "humanitarianism," either to preclude totalitarians from writing in different meanings, or to deter them from raining destruction from the skies.

\section{The Balancing of Security and Pollution in Determining REASONABLENESS}

The argument against the tests based on "pollution"222 introduces no principle or policy not already considered in connection with the law of the sea in general: it merely focuses attention upon one modality of possible interference with the competing uses of navigation and fishing. No international tribunal has ever held a nation-state liable in damages for pollution of the seit, or declared the existence of a duty to desist. ${ }^{223}$ The international regtilation of pollution is at its merest inception, with prescriptions yet to be formullated. ${ }^{224}$ In this state of affairs, a decision-maker confronted with competing claims with respect to pollution and freedom of navigation and fishing can only resort to such sources as "general principles of law recognized by civil-

to use the Atomic Bomb, 194 Harpers Mag. 97 (1947). See also Stowell, The Lanes of War and the Atomic Bomb, 39 AM. J. InT'L L. 784 (1945); Borchard, The Atomic Bomb, 40 AMr. J. INT'L L. 161 (1946).

221. Phillips, supra note 218, passin; Spaak, The Atom Bomb and N.ATO, 33 Lowrtan AfraIRs 353 (1955). Contrast the attitudes expressed by Phillips and Spaak with the unrealistic attitude in SpAIGHT, op. cit. supra note 214, at 274, approving area saturation bombing with its total destruction, yet concluding that atomic weapons are unlawful.

222. Margolis, pp. 641-43.

223. See the Trail Smelter Case, Award of April 16, 1938, and March 11, 1941, 3 U.N. Rep. Int'l Arbitral Awards 1905, 1963; 1 Gided, Droit International Pudlic de LA MER 480-84 (1932). See, however, the carefully limited statement in 1 HYDE, InTERNATTONAL LAW 757-58 (2d ed. 1945).

224. The extremely limited degree of international agreement on restriction of sea pollution is indicated by the Convention drafted and opened for signature at the International Conference on Pollution of the Sea held in London during April and May 1954. Article II exempts naval auxiliaries, ships under 500 tons gross tonnage, ships in the whaling industry, and ships proceeding to ports not equipped with facilities for disposal of oil waste, from the obligation to refrain from discharging noxious substances in the restrictcd zones created by the Convention. Art IV exempts discharges to secure the safety of the ship, discharges resulting from damage or unavoidable leakage, and discharges of sediment not susceptible of being pumped or resulting from certain processes, "provided that such discharge is made as far from land as is practicable." Article III restricts enforcement of the Convention to the state of registration. International Convention for the Prohibition of Pollution of the Sea by Oil (mimeo unchecked copy 1954) (on file in Yale Law Library). 
ized nations," and considerations "ex acquo et bono." The decision-malker thus resorting to national prescriptions with respect to "nuisance" generally, and the pollution of waters in particular, finds himself, despite an elaborate façade of technical terms, instructed only to apply the familiar and indispensable test of reasonableness. 226 The innumerable forms which such controversies may indeed take makes it impracticable to adopt any standard more explicit than that of reasonableness, determined by the familiar process of balancing the "utility of the conduct" causing damage, and the "gravity of the harm" to the injured party. ${ }^{227}$ In applying municipal law to controversies between nation-states, there is, however, one new and most significant factor which must be taken into account in determining reasonableness, and that is the factor of security. Any balancing of interests which failed to take account of the demands for security which states must make in the contemporary world would, of course, be most unrealistic.

The attack upon the legality of the tests attempted by Dr. Margolis is, thus, not only couched in terms of an inadequate formulation of doctrine, but depends ultimately upon analogies which are fantastically inapt in both fact and policy. By focusing upon "serious magnitude" of damage as the sole legal test, ${ }^{28}$ he neglects to consider the most important element in the problem: the overriding utility of the tests to the free world. This one-sided method of calculation is, of course, not to be found in the very cases he cites. ${ }^{200}$ The principal case relied upon, the Trail Smelter ${ }^{230}$ arbitration, is indeed a pass-

225. Stat. Int'i CT. Just. art. 38, IIT 1(c), 2.

226. For extensive citation of authorities in American law, see MfCDougal \& HAnER, Property, Wealth, Laind 439-41 (1948). See also 1 Oppentmems-Lauterpacki 313 n.6; Gutteridge, Abuse of Rights, 5 Caxrb. L.J. 22 (1932); Winfield, Nuisance as a Tort, 4 CaMr. L.J. 189 (1932); Haab, Das Sachenrecht, in 4 Kosmentar zuar Scnweizeriscreat ZinigesetzBuch, pt. 1, at 442-47 (2d ed. 1935); WarNeyer, Das Bürgerdiche GesetzBUCH 604-07 (7th ed. 1938).

227. Restatenent, TorTs $\$ \$ \$ 27,82 \$$ (1939). For explicit recognition of the "relativity" of the rule for determining what constitutes "an injurious act," in the only international proceeding ever to consider the liability of a nation-state for air pollution, sce the Trail Smelter Case, Award of April 16, 1938 and March 11, 1941, 3 U.N. REP. Isr'L Arbitral Awards 1905, 1963, citing the very relevant case of Aargau v. Solothurn, 41 Entscheidungen des Schweizerischen Bundesgerichtes pt. 1, at 126, 137 (1915) (impossibility of preventing all conceivable danger should not prevent pursuance of a necessary or desirable activity). See also notes 231,241 infra.

228. Margolis, p. 642.

229. See New Jersey v. City of New York, 283 U.S. 473, 480-83 (1931); New York v. New Jersey, 256 U.S. 296, 314 (1921), cited by Margolis, p. 642 n.67. The Court did not find it necessary to balance the "magnitude of the harm" and the "utility of the conduct" in Missouri v. Illinois, 200 U.S. 496 (1906), because it found that no harm whatever had been proved. Id. at 526. It did, however, emphasize that unless the case was "of serious magnitude, clearly and fully proved," it would not intervene at all. Id. at 521. Dr. Margolis has, thus, taken the maxim do minisnis non curat lex for the whole law of nuisance. For a discussion of the balancing prueess in the Trail Smelter Case, see note 231 infra.

230. Award of April 16, 1938 and March 11, 1941, 3 U.N. Rep. Int'L Andimal AwARDS 1905. 
able illustration of the balancing process upon which the law of nuisance depends. ${ }^{231}$ But the fact that a copper company in British Columbia was required to take measures available to it to minimize damage to a downwind agricultural community, scarcely reflects policies relevant for appraising the reasonableness of measures taken in mid-ocean by a nation-state faced with imminent threats of atomic attack. Similarly, cases in which the United States Supreme Court settles internal disputes between member-states of the union are relevant only for their emphasis upon the underlying policy of reasonableness. ${ }^{232}$ Such internal disputes do not raise the issues of external security, since under our federal system it is the national government which is charged with responsibility for security and most other problems relating to the high seas. ${ }^{233}$

The facts available as to the extent to which water and fish were made radioactive by the tests, and in what areas, leave much to be desired. Newspaper reports originating with segments of the Japanese press infriendly to the United States, for various reasons, exaggerated the effects of the tests with "evident malice," 234 and no complete, authoritative reports are yet available. It is not clear whether fish found to be dangerously radioactive were caught within or without the largest warning zone, established after the effects of the March 1st test became apparent, ${ }^{235}$ so that it is not possible to say whether

231. In the Trail Smelter Case, Award of April 16, 1938 and March 11, 1941, 3 U.N. REP. INT'L ARBitral Awards 1905, the arbitrators recognized the necessity of welchin": all the circumstances when they defined "an injurious act," in effect, as an mircasona"ly injurious act. Id. at 1963. The decree permitted the smelter to continue in operation and to emit sulphur dioxide fumes in an amount presumably deemed reasonable. Id. at 1974 et seq. Trail Snelter is characterized as a "passable" illustration because it involved a balancing process on one level only. The tribunal did not clearly distinguish the separite questions whether damages could be recovered, and whether injunctive relief could be obtained. See notes $240-41$ infra.

232. See cases cited note 299 supra; Connecticut v. Massachusetts, 282 U.S. $66_{0} 0$ (1931).

The arbitrators in the Trail Smelter Case, Award of April 16, 1938 and March 11, 19.11, 3 U.N. REP. INT'L ARBITRAL AwARDS 1905, 1964, stated that such decisions are relevant where "no reason for rejecting such precedents can be adduced from the limitations of sovereignty inherent in the Constitution of the Unitcd States." (Emphasis added.)

233. See United States v. California, 223 U.S. 19, 34-36 (1947). Even in the absence of an external security problem, the Supreme Court has often emphasized its unwillingness to enjoin action undertaken by a "quasi-sovereign" state. See, c.g., New York v. New Jersey, 256 U.S. 296, 309 (1921) ; Missouri v. Illinois, 200 U.S. 496, 521 (1906).

234. Arnold, Effects of the Recent Bomb Tests on Htman Beings, 10 Butis. Atom. SCIENTISTS 347,348 (1954).

235. Margolis, p. 638, asserts that radioactive fish were caught outside the MarchMay 1954 warning zone. These allegations are supported by a wire-service report, reprinted in the N.Y. Times, which quotes Professor Takajiro Mori of Tolvo University to the effect that radioactive fish were being caught "off Formosa" and "off Japan." In a somewhat inconclusive letter to the authors, Professor Mori suggests that by "off" Japan and Formosa he meant "about 450 miles from Bikini," which would be some 1500 miles from Japan and 2100 miles from Formosa, on the edge of the March-May warning area (450 miles in radius). Letter from Professor Takajiro Mori, Fisheries Dept., Faculty of $\Lambda g^{\prime} i-$ culture, Tokyo University, Hongo, Tokyo, Japan, to the Yale Law Journal, March 4 , 
safety measures in addition to the establishment of an adequate warning zone would be necessary if and when future tests are conducted. It seems clear that no injuries whatever resulted from consumption or handling of fish rendered radioactive by the tests, or from radioactive sea water. ${ }^{230}$ The safety measures taken by the Japanese Government were understandably drastic, resulting in

1955, on file in Yale Law Library. The AEC has consistently maintained that no danger from radioactive fish exists outside the test area. AEC Semi-Anuual Report, excerpted in N.Y. Times, July 31, 1954, p. 1, col. 3. See also N.Y. Times, April 1, 1954, p. 20, col. 5.

No responsible source has yet made an unqualified assertion that any fish caught were dangerous to human beings. See Arnold, supra note 234, at 347-48; Japan Information Bull. No. 4, pp. 6-7 (Information Section, Embassy of Japan, Sept. 29, 1954). Arnold states that radioactivity in fish tends to concentrate in the liver, kidney, and other special organs, leaving the meat normally consumed relatively free of activity, "even in the most highly contaminated specimens . ..." He concludes that "it seems likely . . . that . . . the tolerance level was set too low. It is unfortunate that 'normal' catches were not available for comparison." Arnold, supra note 234, at 348. Arnold's account of the facts suggests that (perhaps excepting condemnation of the fish in the open hold of the Fulurryss Marm), the safety measures taken by the Japanese Government were valuable largely as an antidote to popular alarm. No difficulty with radioactive fish was experienced anywhere in the Territory of the Pacific Islands, although fishing was not restricted except in the immediate test area. See Communication from Deputy High Commissioner, Trust Territory of the Pacific Islands, to the Yale Law Journal, Feb. 25, 1955, on file in Yale Law Library.

Although the "fairly indisputable facts" alleged by Margolis, pp. 637-39, seem dubious in the extreme, we assume, for purposes of the judgments made in the text above, that safety would require monitoring of deep-sea catches from a broad area in the North Pacific for a period of time following a test series.

For a compendious collection of the more fantastic press reports which have appeared concerning not only radioactive fish but miscellaneous meteorological and other alleged effects of the tests, see Laurents, Experiment in Amihilation, 5 CoNTEarr. Issurs 214 (1954).

236. See Japan Information Bull. No. 4, supra note 235, at 6-7, reporting on the test damage, and listing no casualties except the crew of the Fuluryu MFaru. Compare Mforgolis, p. 637, citing a third-hand wire service report to the effect that five crew-members of a Japanese freighter which passed within 1200 miles of the tests "were reported suffering from radiation sickness" and that doctors "were quoted as saying the five men were 'gradually recovering.'" N.Y. Times, June 5, 1954, p. 2, col. 6. The AEC has asserted that radioactivity borne on ocean currents would disperse to a point at which it would be "undetectable" within 500 miles or less. N.Y. Times, April 1, 1954, p. 20, col. 6.

Dr. A.H. Sturtevant, geneticist at the California Institute of Technology, cited by Margolis, p. 639 n.58, two weeks after his ominous speculations were excerpted in the N.Y. Times, wrote to caution that the danger at present fallout rates was very small, and that he did not think people should be unduly anxious about the problem. N.Y. Times, Jan. $30,1955, \S 4$, p. 9, col. $\$$. The AEC later announced that the total amount of radiation from "all nuclear detonations to date," has amounted to the equivalent of one chest $\mathrm{x}$-ray per person. Statement by Lewis L. Strauss, Chairman, USAEC Press Release, Feb. 15, 1955 , p. 4. Amounts of radiation larger than this by some hundreds of times are habitually used by physicians and dentists for diagnostic purposes, and are, of course, considered negligible. See generally Ritter, et al, Rocntgen Doses during Diagnoslic Procedurcs, 59 Radiology 238 (1952). For the conclusion, buttressed by substantial data and detailed calculations, that the long-range radiation effects of tests are "minute" and "of a low order" in comparison with the natural background radiation in the earth and atmosphere, sce Eisenbud \& Harley, Radioactive Dust from Nuclear Delonations, 117 Scre:ces 141, 147 (1953). 
the condemnation of some 176 tons of fish, but were 100 per cent effective. ${ }^{237}$ Domestic tuna prices in Japan plummeted to 50 per cent of normal in April 1954, after sensationalized accounts of the test effects were published, but exports were unaffected. ${ }^{238}$ In view of all the facts now known, any serious attempt to balance the stake of the free world in the tests against the damage resulting from pollution-damage which has taken the exclusive form of financial damage for which compensation has been paid-must reach, we stibmit, the conclusion that the tests are reasonable and hence lawful.230

It might of course be concluded, by analogy from municipal law, that although under all criteria of reasonableness a nation-state is entitled to conduct such tests under contemporary conditions, it should still be held responsible in damages for any inevitable injuries to innocent parties. In every mature legal system the balancing process which determines whether liability exists is repeated in answering the entirely separate question whether the liability-creating conduct may be continued. ${ }^{240}$ No international tribunal has yet unequivocally faced the issue whether a state may continue to carry on conduct for which it is liable in damages, ${ }^{241}$ but sound policy

237. Japan Information Bull. No. 4, pp. 6-7 (Information Section, Embassy of Japan, Sept. 29, 1954).

238. Ibid. Compare Margolis, p. 638, asserting that exports "became increasingly difficult."

239. Since the attack on the tests was couched in terms of "justice and equity;" we have preferred to meet it directly and on the merits. It may appropriately be noted, however, that other obstacles to recovery would have to be surmounted before the question of reasonableness could even be reached. Thus, the most advanced statements of pttblicists supporting international liability for sea pollution, c.g., 1 HYDE, INTERNATIONAL LAW 757-58 (2d ed. 1945), have referred to damage suffered by a state or its nationals zeithin territorial zeaters, where states have acknowledged property rights. Similarly, liability for nuisance in private law is assessed for infringement of property rights. In the present state of world prescription about fisheries, it might at least be questioned whether states have property rights of sufficient degree in fish swimming in the high seas to be entitled to damages for injury to them. See note 224 supra. Cf. however, the references to "rights" and "interests" of states in high seas fisheries in connection with claims to contiguous zones for fishery conservation, discussed in text at notes 120-24 supra.

The captious might wonder, again, if "freedom of the seas" is an absolute, why such absolutism does not include the freedom to pollute. See Margolis, p. 634 .

240. For citation of authorities in American law, see McDougnl \& Haver, Propentr, Wealth, Laid 439-41 (1948). See also Hanbury, Modern EQuity 625 (6th ed. 1952); Snell, Princtples of Equity 593-94 (22d ed., Rivington 1939); 65 Entscheidungen des Sch weizerischen Bundesgerichtes pt. 2, at 157 (1940); 40 id., pt. 2, at 445,450 (1915) (interpreting $\$ 684$, Swiss Civil Code). The same legal result is achieved in some civil law countries by administrative process. See Loi de 19 decembre, 1917, [1919] DNuLOz Périodique pt. 4, at 10 et seq., as amended, Loi de 20 avril, 1932, [1932] i $d$. pt. 4, at 161, Loi de 2 fevrier, 1942, [1942] Dalloz Analytique 66; Gabolde, Manuel Juridigue ins Établissenrents DangereuX, Incommodes et INSAlubres (1951) ; Bürgerliches GesetzBUCH $\$ 906$ (4th ed., Hoeniger 1927); 3 Staudinger, Kommentar zun Bükcerliches Gesetzbuch 308-26 (9th ed., Kober 1912); Gewerbeordnung, \$26 (5th ed., Neukamp 1901) ; Stier-Somio, Kommentar zUr Geiwerbeordnung 82-83 (2d ed. 1923).

241. Cf. Trail Smelter Case, Award of April 16, 1938 and March 11, 1941, 3 U.N. REP. INT'L ARBITRAL AwardS 1905, 1963, in which the tribunal avoided answering this 
decrees that international law should parallel municipal law in this respect. $2 \pm 2$ Although no legal issues were formally resolved between Japan and the United States, the settlement in fact reached a desirable legal result. Japan explicitly refused to demand that the United States discontinue its tests, ${ }^{2,3}$ and the United States paid two million dollars in damages "without reference" to questions of legal liability. 244 Only third parties, unembarrassed by responsibilities for the defense and security of the free world, seem unable to perceive the need for an appropriate discrimination between remedy for damage and mutual tolerance for vital interests.

\section{The Expectations IVtth Respect to Security Created by rhe Charter and Trusteeship Agreearent}

After wresting the islands of the Pacific from Japan at an immense cost in blood and treasure, the people of the United States were determined that these strategically important islands should never again be allowed to fall into the hands of an aggressor nation or to jeopardize the security of the United States in any way. An influential segment of public opinion favored annexation of the islands as the only satisfactory solution, but the American anticolonial tradition made annexation repugnant to many. 24 The trusteeship provisions of the United Nations Charter, proposed in large part by the United States with the Pacific islands in mind, ${ }^{240}$ reflect a compromise between these demands for annexation and our antipathy to colonialism. The

question squarely by referring to the clause of its compromis which emphasized the desire of the parties to reach a final solution of the controversy. The United States in Troil Smelter argued that a state may not continue activity which inflicts legally compeneable "injury," $i d$. at 1962-63, an attitude which may be responsible fur its desire to settle with Japan "without reference" to questions of legal liability. See text at note 244 infra.

242. See Comment, 37 YALE L.J. 96 (1927), clarifying policies embodied in municipal law, which are rather obviously applicable in the contemporary world arena.

243. Foreign Minister Katsuo Okazahi to the Japanese Diet, reported in N.Y. Times, April 2, 1954, p. 4, col. 6. Mrr. Ohazaki stated that Japan could not possibly ask the United States to discontinue thermonuclear tests unless the Soviet Union stopped also. and that it would cooperate with the United States in its testing activities in the belief that the tests "will contribute to world peace." MIanchester Guardian, March 24, 1954, p. 1, col. 2. For refusals by other governments to ask that the tests be halted, see X.Y. Times, April 6, 1954, p. 12, cols. 3, 5 (U.K.), April 7, 1954, p. 3, col. 1 (Canada) : X.Y. Herald Tribune, April 10, 1954, p. 2, col. 7 (Australia); French and Belgian representatives in Standing Committee on Petitions, U.N. Trusteeship Council, Summary Rccord (Doc. No. T/C.2/SR.198) (1954) ; New Zealand, Republic of China, Haiti, and El Salvadur in U.A. Trusteeship Couscil OfF. Rec, 14th Sess., 561st meeting 246-48 (1954).

244. N.Y. Times, Jan. 5, 1955, p. 6, col. 1.

245. For review of the annexation controversy, and identification of public figures supporting the various points of view, see $\mathrm{A}$ (cKay, Intemational Trustceship-Fule kn United Nations in the Colonial World, 22 Foreigs Policx Rervars 54, 63-65 (1946); SoHN, WorLd LAw 638 (1950).

246. MLCKay, supra note 245, at 57-58. See also Hearings bofore the Senate Cimmiltec on Forcign Relations on the Charter of the United Vations for the Mainlenance of Lneruational Peace and Security, 79th Cong., 1st Sess. 112-18 (1945). 
system of administration ultimately established in the Pacific islands similarly expresses both the demand of the United States for the utmost freedom of action in matters relating to the security of itself and the world, and its concomitant willingness to assume a duty to promote the welfare of the islands' indigenous inhabitants.

The provisions of the Charter relating to dependent areas and trusteeship areas incorporate and implement both these complementary goals of security and humanitarianism. ${ }^{247}$ The framers of the Charter discarded as unrealistic the non-fortification provisions of the League Covenant, which forbade fortification or other military use of " $B$ " and " $C$ " mandates, 248 and substituted the policy expressed in Article 76, that the first of the basic objectives of the trusteeship system should be "to further international peace and security." Article 84 specifically obligates each administering authority to ensure that the trust territory shall "play its part" in the maintenance of international peace and security, and empowers the administering authority to make use of volunteer forces, facilities, and assistance from the trust territory. This fundamental shift from League policy is further emphasized by the fact that the word "security" appears no less than three times in Article 73, which declares the obligations of member-states with respect to non-self-governing territorics generally. ${ }^{249}$

At the instance of the United States, moreover, a new institution, the "strategic" trusteeship, was created by Article 82 of the Charter. This institution was proposed by the United States with a view to creating an appropriate regime for the Pacific islands, ${ }^{250}$ and they are, incleed, the only territory

247. "The chapters of the Charter relating to dependent territorics and trusteeship create the machinery to accomplish these purposes [raising the standards of colonial administration, etc.] and at the same time to make it possible fully to protect the vital security interests of the United States with respect to any territories in the Pacific and elsewhere which, by later agreement, may be included in the trusteeship system." Hearings, supra note 246, at 113. See also Goodrich \& HaMrgro, Charter of tire United Nations 452-54 (1949) ; Gross, United Nations Trusteeship and League of Nations Mandate Systcms, 4 INDIA QUARTERLY 224 (1948).

248. League of Nations Covenant art. 22, paras. 5, 6. See Bentwich v. Maktin, . Charter of the United Nations 156-57 (1950) ; Hall, Mandates, Dependencies and Trusteeships 279-80 (1948).

249. Cf. Kelsen, Law of the Uniten Nations 557-58, 559 (1950): "But it is significant that in an Article the main purpose of which seems to be to provide for protection of non-self-governing peoples, the promotion of international peace and security which may impair this protection, is referred to twice." Professor Kelsen also notes that the implementing section of the article is made subject to "such limitation as [national] security and constitutional considerations may require." Id. at 561 .

The preeminence of security in the trusteeship provisions of the Charter is of course a reflection of the fact that the principal purpose of the Charter as a whole is the maintenance of international peace and security. For elaboration of this major purpose of the Charter, see McDougal \& Gardner, The Velo and the Chartcr: An Interpretation for Survizal, 60 YALE L.J. 258 (1951) ; Gross, supra note 247, at 225, 238.

250. McKay, supra note 245 , at 57 ; Hearings, supra note 246 at $113,116$. 
to which it has ever been applied. ${ }^{251}$ All functions of the United Nations relating to strategic trusteeship territories were, as was provided in Article 83 , to be exercised by the Security Council, where any of the five permanent members could veto any action which it believed might threaten its own individual security. ${ }^{252}$ In the same Article, however, the basic objectives of the trusteeship system set forth in Article 76, including those with respect to the welfare and fundamental human rights of the inhabitants of an area, were made applicable to "strategic" trusteeships, and the Security Council was directed, "subject to the provisions of the trusteeship agreements and without prejudice to security considerations," to avail itself of the assistance of the Trusteeship Council to perform functions relating to political, social, and educational matters in strategic areas.

The principal constitutional document under which the United States governs the Territory of the Pacific Islands is the Trusteeship Agreement for the Former Japanese Mandated Islands, ${ }^{253}$ effective July 18, 1947, in which the Security Council "satisfied itself" that "the relevant articles of the Charter have been complied with."254 This fundamental charter of authority confers upon the administering authority "full powers of administration, legislation and jurisdiction" over the territory, and authorizes it to apply, "subject to any modifications which the administering authority may consider desirable, such of the laws of the United States as it may deem appropriate to local conditions and requirements."25j Article 5 of the agreement reemphasizes the departure from the non-militarization regime of the League by conferring upon the administering authority a power similar to the "war power" of the United States Constitution, in terms limited only by denial of the power of conscription. The United States is empowered:

" 1 . to establish naval, military and air bases and to erect fortifications in the trust territory;

2. to station and employ armed forces in the territory; and

3. to make use of volunteer forces, facilities and assistance from the trust territory ...."256

251. GOODRICH \& HAMrBRo, op. cit. stpra note 247, at 453.

252. U.N. CharTER art. 27, para. 3.

253. 61 Stat. 3301, T.I.A.S. No. 1665, 8 U.N. Treaty Ser. 189 (hereinaiter cited as Trusteeship AgreEMIENT).

254. Trusteeship Agreement, Preamble.

255. Id., art. 3. For the suggestion that full powers of administration, legislatiun, and jurisdiction are indistinguishable from "sovereignty," for all practical purpuses, see Vedsvato, Les Accords de Trtelle, 76 Hague Recueil 613, 655 (1950).

256. Trustership AgreeMrent art. 5.

The Soviet Union early took the position that the utilization of trusteeship territuries for the support of "international peace ard security" was only admissible where the administering authority was acting pursuant to an agreement with the Security Council. This view would of course subject all military activities in trusteeshig territories to the veles powers of the five permanent members, including the Soviet Lnion. The Charter is, hwwerer, consistent with some five different procedures for maintaining "internativnal pease and security," only two of which are subject to prior control by the Security Council, sse 
The Agreement gives to the United States control over the foreign affairs of the Territory, ${ }^{257}$ power to combine it with other territories under United States jurisdiction for customs, fiscal, or administrative purposes, ${ }^{268}$ power to discriminate in favor of the United States in economic matters despite the equal treatment clause of the Charter, ${ }^{260}$ and power to bar all U.N. supervision in "areas which may from time to time be specified" by the United States as "closed for security reasons."260 The terms of the Agreement may not be altered, amended, or terminated without the consent of the Administering Authority. ${ }^{261}$

The comprehensive powers thus granted the Administering Authority are, however, accompanied by certain parallel duties. The Charter itself, of course, requires the administering authority to ensure the political, economic, social, and educational advancement of the inhabitants, their just treatment, and their protection against abuses, and to encourage respect for human rights and for fundamental freedoms for all without distinction as to race, sex, language, or religion. ${ }^{262}$ All members of the United Nations agreed, further, to accept as a "sacred trust" the obligation to promote to the utmost, "within the system

note 296 infra, so that the Soviet Union's proposed interpretation would have been an unwarranted extension of its power to thwart defense preparations. The Soviet view was rejected by the General Assembly and its Fourth Committee. See Goodrich \& Hammio, op. cit. supra note 247, at 458-59; Gross, United Nations Trustecship and Leaguc of Nations Mandate Systems, 4 India QUARTERLy 224, $227-28$ (1948).

In Committee II/4 at the San Francisco Conference, the delegate from Egypt moved to amend the Working Paper submitted by the United States (eventually Article $\& 4$ of the Charter, from which the military powers of the United States as Administering Authority derive) to provide that the administering authority "[may] . . . under the control of the Security Council" utilize facilities and assistance from trusteeship territories. Doc. No. 580, II/4/24, 10 U.N. Conf. INT'L OrG. Docs. 488 (1945). In support of the motion it was said that without the amendment the power of the administering authority to make use of facilities and assistance in trusteeship territories would "be absolute, a situation which would be undesirable for the peoples of the territory." Ibid. The amendment was defeated by 26 votes to 2 . Ibid. See also Gross, supra, at 231 : "the new approach is dominated by considerations of national security to an extent and in a manner unknown to the Mandate System . . . The Trusteeship System appears to be founded on the idea of the paramountcy of the national security interests of the administering authority."

The limitation that only "volunteer" forces from trust territories be utilized by administering authorities, U.N. CHARTER art. 84, was insisted upon by the United States. United Nations Secretariat, The Question of Fortifications and Voluntecr Forces in Trust Territories, U.N. Doc. No. A/C.4/40, at 3 (1946).

257. Trusteeship Agreenent arts. 8(4), 10.

258. Id., art. 9.

259. Id., art. 8(1).

260. Id., art. 13. The Security Council might, of course, investigate any dispute or situation to determine whether its continuance "is likely to endanger the maintenance of international peace and security," under U.N. CHARTER arts. 34, 39, in the same manner and to the same extent as in relation to any other part of the world.

261. Trusteeship AgreEnent art. 15.

262. U.N. Charter arts. 73(a), 76(b), (c). 
of international peace and security established by the ... Charter, the wellbeing of the inhabitants of these territories."203

In the Trusteeship Agreement, the United States voluntarily accepted greater and more specific obligations than were required by the Charter, to promote the political, economic, social, and educational advancement of the inhabitants. ${ }^{264}$ Economic advancement was to be secured by regulating the use of natural resources, encouraging the "development of fisheries, agriculture and industries," protecting the inhabitants "against the loss of their lands and resources," and improving "the means of transportation and communication."265 The administering authority was to promote the social advancement of the inhabitants, and to this end to

"protect the health of the inhabitants; control the traffic in arms and ammunition, opium and other dangerous drugs, and alcohol and other spirituous beverages; and institute such other regulations as may be necessary to protect the inhabitants against social abuses . . . ."

Other obligations relating to the political and educational advancement of the inhabitants, and to civil rights, are similarly detailed." ${ }^{-67}$

Atomic tests had been held at Bikini in 1946,208 and reports of the test results filled the world's newspapers throughout the period when the Trusteeship Agreement passed through the stages of preliminary discussion, drafting, and presentation of the Agreement to the Security Council. In this context, the debate on the Agreement in the Security Council confirmed by explicit multiple references that the United States was to be accorded virtually unrestricted powers in matters relating to security, whether its own or that of the world. ${ }^{269}$ The United States made its position clear by refusing even to consider any amendments which could be interpreted as detracting from its powers or limiting its complete discretion as Administering Authority in security matters. At one point in the debate United States Representative Warren R. Austin asserted that, while the United States would not exercise its veto power, if amendments unacceptable to the United States were adopted the agreement would be withdrawn, with American administration of the territory continuing in any event. ${ }^{270}$

The Trusteeship Agreement was drafted by the United States State De-

263. Id., art. 73.

264. Goodrtch \& Hazrbao, Cearter of the United NatioNs 453 (1949).

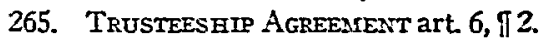

266. Id., art. 6, $\{3$.

267. Id., art. 6 , fif 1,4 , art. 7 .

268. N.Y. Times, July 1, 1946, p. 1, col. \&; id., July 25, 1946, p. 1, cul. \&.

269. See, particularly, U.N. Seccrity Couscil OFF. Rec, 2d year, 124th meeting $664-65$ (1947) ; id., 123d meeting 627, 628, 636, 637-38; id., 119th meeting $528,530-31$; id., 113 th meeting 412 .

270. Id., 124th meeting 670. See also Schuarax, Internatiunal Polirics 599 (4th ed. 1948) ; U.S.-U.N. Infororation SER., No. 21, at 6 (U.S. Dep't State 1947). 
partment after consultation with the War and Navy Departments, ${ }^{271}$ and in the view of its draftsman did not impinge upon United States "attonomy with respect to national security ... in the slightest degree."272 As originally drafted, Article 3 of the Agreement gave to the administering authority full powers of administration, legislation, and jurisdiction over the territory "as an integral part of the United States."273 An amendment to delete the latter phrase was introduced by the Soviet Union, apparently to negate any inference that the Territory was ultimately to be annexed to the United States. ${ }^{274}$ The United States accepted the amendment, but was careful to make clear that it was not to be considered as having diminished its powers in the Territory by doing so:

"I want to say the following, because I think these words should be included in the record of this solemn proceeding ..... In agreeing to this modification, my Government feels that for record purposes it shoulil affirm that its authority in the trust territory is not to be considered as in any way lessened thereby ..... For administrative, legislative and jurisdictional convenience in carrying out its duty towards the peoples of the trust territory, the United States intends to treat the trust territory as if it were an integral part of the United States."275

After unanimous approval of the agreement by the Security Council, public hearings were held by the United States Congress to consider a joint resolution authorizing the President to approve it. Every witness was asked whether the agreement restrained the freedom of action of the United States in any way in the use of the Pacific islands for security purposes. Fach witness replied in the most emphatic terms that the agreement gave the United States a completely free hand. The following colloquy is typical:

The Chairman (Senator Vandenburg). Mr. Secretary, ... I I would like to have your opinion as to whether there is anything in your opinion which in any degree handicaps or restrains our freedom of action in the use of these islands for security purposes.

Secretary MARShall. Mr. Chairman, I think the terms of the agree* ment have been so carefully drafted from the security point of view that there is no doubt in my mind that our security and our responsibility

271. Hearings before the Senate Committee on Foreign Relations on S.J. Res. 143, 80th Cong., 1st Sess. 11 (1947).

272. Colloquy between Senator Vandenburg and Benjamin Gerig, Chief, Division of Dependent Area Affairs, Department of State. Id. at 21.

273. Draft Trusteeship Agreement for the Japanese Mandated Islands, Fan EAstran SER., No. 20, at 4 (U.S. Dep't State 1947).

274. U.N. SeCurity Council OfF. ReC., 2d year, 113th meeting 415 (1947). The purpose of the amendment is inferred from the general tenor of the several amendments offered by the Soviet Union, ibid., its acquiescence in the United States' qualified acceptance of the principal amendment, see text at note $275 \mathrm{infra}$, and from the understanding of the purpose of the amendment revealed by other nations' representatives in debate. Sce, e.g., U.N. Security Council OfF. ReC., 2d year, 122d meeting 630-31 (1947).

275. Id., 116th meeting 473.

276. Id., 124th meeting 473 . 
for general security are fully provided for. I refer the members of the committee to articles 3,5 , and 13 of the agreement. I believe all our interests are fully conserved.

The ChaIRMax. So far as the use of these islands for security purposes is concerned, in what degree do we have less authority than we would have if we continued to run them the way they are being run now:

Secretary MarSHALL. I think under the terms of this trusteeship agreement we are not limited at all ....

The Champmax. So that you would say, as I understand you, that under the terms of the trusteeship agreement we have the same freedom of action on behalf of national security as we would have if we vere continuing the administration of the islands under our present exclusive control?

Secretary Marshall. I think that is correct, sir..$^{2 \pi i}$

The purpose of the United States to secure virtually unlimited powers with respect to security matters in the trust territory was made clear not only to the United States Congress and the Security Council but to the whole world. Almost every commentator who has had occasion to discuss the agreement has remarked upon the broad scope of the security powers it confers, ${ }^{278}$ and those who favor strong international control over trust territories have bitterly attacked it as "an instrument of annexation, tempered with expressions of benevolence."279 The publicist Walter Lippman advocated annexation, calling it "hypocritical" to place the islands under trusteeship by an agreement permitting us "to do anything and everything we would do if we had annexed them."280

The view that the Agreement gave to the United States virtually unlimited security powers is confirmed by the subsequent conduct of both parties to the agreement. In December 1947, it was announced that experiments relating to nuclear fission would be held at Eniwetok, ${ }^{281}$ and the United States advised

277. Hearings, supra note 271, at 5. For comparable statements by Secretary of War Patterson, Secretary of the Navy Forrestal, General Eisenhower, and Admiral Nimitz, sce id. at 11-2, 14-15, 18-19, 19-20. Secretary Patterson said, "The obligations we talie under the agreement are merely obligations that we would fulfill to any people under our flag. even apart from the engagements and covenants in this agrcement, as I sce it-such things as their political ...., économic . . . social . . . and educational development, and the basic freedoms that we would accord any people that were living under the United States flag." Id. at 12.

278. See, e.g., Bentwich \& MARtin, Charter of the United Natio:ts 155-\$6 (1950); Goodrich \& Haxrbro, Charter of the United Nations 453-54 (1949); Scrusan, of. cit. supra note 270, at 599; Gross, Unitcd Nations Trusteeship and Lcague of Nolions Mandate Systems, 4 India QuARTERLy 224 (1948).

279. Schunsax, op. cit. supra note 270 , at 599 .

280. N.Y. Herald Tribune, Feb. 2, 1946, p. 13, col. 2. For an attack on Mlr. Lifpmann's views, see 63 Christian Century 231 (1946). See also Michay, International Trtustecship-Role of United Nations in the Colonial World, 22 Forergx PoLICr Reronts 34 (1946).

281. N.Y. Times, Dec. 2, 1947, p. 1, col. 6. 
the Security Council that the area was "closed" for this specific purpose.282 Continuous reports of testing activities emanated from Eniwetok from 1947 onward, and tests relating to thermonuclear development were conducted in 1951 and $1952 .^{283}$ In April 1953, the Security Council was notified that the United States had extended the "closed area" to include Bikini, again for the specific purpose of conducting fests "relating to nuclear fission." this course of action had in the beginning been the subject of official correspondence and perfunctory comment in the Security Council, ${ }^{285}$ and was a matter of continuing public knowledge, no nation, not even the Soviet Union, expressed any surprise or made any protest whatever.

It would scarcely seem necessary to recall, if various commentators had not focused upon the limitations in the Charter and the Trusteeship $\Lambda$ grecment without adequate consideration of the powers granted, ${ }^{286}$ that the most fundamental principle of treaty interpretation, especially applicable to great constitutional charters, is "that the Treaty must be read as a whole, and that its meaning is not to be determined merely upon particular phrases which, if detached from the context, may be interpreted in more than one sense."287 As Judge Hudson has emphasized, when a treaty sets up a régine, each of its provisions must be construed "by reference to its place in a system."288 Powers can be given rational interpretation only in the context of the limitiltions imposed upon them: and conversely, limitations upon power can be given meaning only by reference to the powers which they are intended to limit. Hardly less fundamental than this principle that international agrecments must be interpreted as a whole, with due regard being given to all parts, is the principle of "effectiveness"-the principle that agreements must be interpreted in context and primarily in terms of the major general purposes, the basic goals and expectations, which they are intended to serve.

282. Letter from Warren R. Austin, Representative of the United States of Amcrica, concerning the conducting of experiments relating to nuclear fission on Eniwetok Atcill in the Trust Territory of the Pacific Islands, U.N. Doc. No. S/613 (1947).

283. N.Y. Times, Nov. 17, 1952, p. 1, col. S; id., May 26, 1951, p. 1, col. 4.

284. U.N. Doc. No. S/2978 (1953).

285. 5 U.N. Security Council Off. Rec., 2d year, $222 \mathrm{~d}$ meeting $2771-72$ (1947).

286. See the argument of the Indian and Soviet representatives on the Standing Com* mittee on Petitions of the U.N. Trusteeship Council, Summary Record, 9-13 (U.N. Doc. No. T/C.2/SR.197) (1954), and Margolis, pp. 643-45.

287. Competence of the International Labour Organisation, P.C.I.J., Ser. B, Nos. 2 \& 3, p. 23 (1922). See also Diversion of Water from the River Meuse, P.C.I.J., Ser. A/B, No. 70, pp. 21, 23 (1937) ; Statute of Memel Case, P.C.I.J., Ser. A/B, No. 49, pp. 312, 317, 321 (1932) ; Polish Postal Service in Danzig, P.C.I.J., Ser. B, No. 11, pp. 39-40 (1925): Santovincenzo v. Egan, 284 U.S. 30, 37 (1931) ; Hamilton v. Erie R.R., 219 N.Y. 343, 353, 114 N.E. 399, 403 (1916) ; 5 Hackworth, Digest of Internatmonal Law 249-50 (1943).

288. Hudson, The Peraranent Court of International Justice 1920-1942, at 648 (1943).

289. Highest recent authority for the paramount importance of this principle is found in the Advisory Opinion of the International Court of Justice on Reparation for Injurics 
Thus the Harvard Research insists that the meaning to be given to an agreement is "not just any meaning which appeals to the interpreter . . . but a meaning which, in the light of the test under consideration and of all the concomitant circumstances of the particular case at hand, appears in his considered judgment to be one that is logical, reasonable, and most likely to accord with and to effectuate the larger general purpose which the parties desired the treaty to serve."200 In the black letter of its proposed Draft Convention on the Law of Treaties, the Rescarch is concise and definitive:

"A treaty is to be interpreted in the light of the general purpose which it is intended to serve. The historical bachground of the treaty, traz'au.: préparatoires, the circumstances of the parties at the time the treaty was entered into, the change in these circumstances sought to be effected, the subsequent conduct of the parties in applying the provisions of the treaty, and the conditions prevailing at the time interpretation is being made, are to be considered in connection with the general purpose which the treaty is intended to serve."

From the perspective of the major purposes of the parties to the United Nations Charter and to the Trusteeship Agreement, recounted in detail above, it almost belies credulity that a critic could suggest that the conclusion is "inescapable" that the hydrogen bomb tests are "clearly at variance" with supposed "unqualified imperatives" of the Charter and the Trusteeship Agreement. ${ }^{292}$ Such a suggestion ignores the broad grants of power to the Administering Authority contained in both documents, and attempts to construe the limitations upon those powers as autonomous, disembodied absolutes. ${ }^{203}$

Suffered in the Service of the United Nations. Advisory Opinion of April 11, 1949, [1949] I.C.J. Rep. 174, 179, 182; accord, International Status of Southwest Africa, Advisory Opinion of July 11, 1950, [1950] I.C.J. Rep. 128, 133. See also Hariard Researcu Draft on Treaties 948-53 (1935); 2 Hyde, International L.iw 1406 et seq. (2d ed. 1945); Lauterpacht, DeVelopaent of INternational L.aW 69-70 (1934); WestLake, IntiterNational LAw 293 (2d ed. 1910) ; Yo, Interpretatrox of Treaties fassin (1927) ; Fairman, The Interpretation of Treatics, 20 Travs. Gronus See'y 123 (1935); JeDougal \& Gardner, The Veto and the Charter: an Interpretation for Surizal, 00 Yale L.]. 358, 26669 (1951) ; Lauterpacht, Restrictive Interpretation and the Principle of Effectriestess in the Interpretation of Treaties, 26 BRIT. Y.B. IxT'L L. 48 (1949); Pollux, The Inferprelution of the Charter, 23 id. 54 (1946).

290. HARVARD RESEARCH, op. cit. supra note 289, at 946.

291. Id., art. 19.

292. See Margolis, pp. 644, 645 .

It may be observed further that Dr. Margolis" "dilemma" with respect to the "duties imposed by the U.N. Charter and the Trusteeship Agreement" that "the greater the precautions taken by the administering authority to protect the health of the Marshallcse people, the greater the infringement of the rights guaranteed them" is, in his uwn words, "not unlike that created by the doctrine of freedom of navigation": it begs the very question in issue, whether the United States" activities are "infringements" of "rights" guaranteed, or "exercises" of "powers" granted, by the Charter and Trusteeship Agrcement.

293. Few people today take seriously attempts so tu construe natiunal cunstitutiuns. It is commonly recognized that grants of power and limitations upon nower are as indivisible as scissors' blades, and must be construed simultaneously in determining the rea- 
The tests conducted by the United States in the islands may be subsumed most easily, in giving effect to the major purposes and expectations of the parties, under the broad powers conferred upon the United States to promote and protect both international peace and security and its own individual security. The Trusteeship Agreement specifically authorizes the use of "facilities and assistance" for the protection of international peace and security, ${ }^{204}$ and the broad powers reserved by the United States with a view to serving its own peculiar security needs have already been recounted.205 The reality of the role of the United States in promoting international peace and security is apparent from its enormous contribution in manpower and material to the collective United Nations action to repel aggression in Korea, and its continuing efforts to act through the United Nations to achieve disarmament, including prohibition of nuclear weapons, and the peaceful settlement of disputes. In an interdependent world, being made ever more interdependent by a continuously developing technology, even a disinterested observer should be able to discern some relation between the security of other nation-states and that of the United States. ${ }^{206}$ Proponents of a free world society and of a world order honoring human dignity should, in particular,

sonableness and, hence, lawfulness of governmental activity. Examples could be offered from the whole structure of constitutional prescription. A particularly striking example may be noted with respect to the First Amendment to the United States Constitution. Although the amendment provides that Congress "shall make 110 law . . . abridging the freedom of speech ...., the Government may limit absolute freedom under many different powers. See, c.g., Schenck v. United States, 249 U.S. 47 (1919) ; American Communications Ass'n v. Douds, 339 U.S. 382 (1950). See also Ex partc Milligan, 71 U.S. (4 Wall.) 2, $124-27$ (1866) ; United States v. Russell, 80 U.S. (13 Wall.) 623 (1872) ; Duncan v. Kahanamoku, 327 U.S. 304, 324, 335 (1945) (concurring opinions of Chief Justice Stone and Justice Murphy).

294. Trusteeship Agreenent art. 5.

At least five modes of pursuing "international peace and sccurity" have been estab. lished under the Charter. Thus, action may be taken by the Security Council, by the "regional" organizations contemplated in U.N. Charter c. 8, by the General Assembly under the "Uniting for Peace" resolutions, by individual nation-states under the "selfdefense" clause of U.N. CHARTER art. 51, and by organizations such as NATO, SEATO, the Brussels Treaty, the Arab League, and the Balkan Union, which are "collective selfdefense" organizations under the same Article. See generally Becketr, THE NokTu ATlantic Treaty, the Brussels Treaty and the Charter of the United Nations (1950); Bebr, Regional Organizations-A United Nations Problem, 49 AM. J. INT'L L. No. 2 (1955); Kelsen, The North Atlantic Treaty and the Charter of the United Nations, 9 Acta Scandinavica Iuris Gentium 42 (1949); McDougal \& Gardner, The Vclo and the Charter: An Iuterpretation for Survival, 60 YALE L.J. 258, 288-92 (1951). Fortunately, only direct action by the Security Council, and possibly action by regional organizations based on Chapter VIII, are subject to prior control by the veto-bound Security Council. Effective use of the Uniting for Peace Resolutions and Article 51 regional organizations depends, of course, on the efforts of individual states to maintain forces and weapons in readiness in case of need.

295. See text at notes 253-61 supra.

296. For some of the interrelations of international and national security, see Wolfers. "National Security" as an Ambignous Symbol, 47 PoL. Scr. Q. 481 (1952). 
have no difficulty in finding a most intimate relationship. Even, however, if it be assumed, that there is no relationship between "international security" and the security of the United States, it is clear that the United States has reserved in the Trusteeship Agreement, in accord with the terms of the Charter, more than sufficient powers to conduct the tests in the interests of its own security.

It has been seen that the comprehensive powers accorded to the United States includes substantially all the powers it would have within its own boundaries, subject only to the exception that its "war" power does not authorize conscription. ${ }^{297}$ The right of eminent domain is implicit in the "full powers of administration, legislation and jurisdiction" $" 98$ and the power "to establish naval, military and air bases and to erect fortifications." 200 It is therefore clear that the United States is empowered to use some land, and some facilities and assistance from the territory, and therefore that the duties of the Administering Authority with respect to the protection of land, encouragement of fisheries, and so on, are not "unqualified imperatives." mental criteria of treaty interpretation, indicated above, it would also appear that the United States is authorized to use some land and facilities for the purpose of testing dangerous weapons: the testing of weapons is indispensable to preparation for defense under war and security powers; the fact that the United States had already tested weapons in the area made continued testing a part of the expectations of all the framers of the Trusteeship Agreement $;^{301}$ and these expectations have been confirmed by seven years' conduct, sans protest, by both parties to the Agreement. ${ }^{302}$ The one remaining question is whether the tests conducted, though clearly subsumable under the powers granted to the United States, have assumed such unreasonable proportions as to violate the duties said to constitute limitations upon its powers. ${ }^{303}$

Since the Pacific Islands became a Trust Territory, the United States has taken Eniwetok Atoll (2.26 square miles of land) for use in connection with its weapons testing activities. ${ }^{304}$ The 137 inhabitants of the atoll were resettled on land of their own choosing from the public domain, where buildings and facilities have been constructed for their use by the Administering Authority, and they have since been regarded as special wards of the government. 305

297. See text at notes $255-60$ supra.

298. TRUSTEESHIP AgREENENT art. 3.

299. Id., art. 5.

300. Margolis, p. 644.

301. See text at notes $268-70$ sipra.

302. See text at notes 281-85 supra.

303. For illustrations of the necessity of a "reasunableness" test in the resolution of any constitutional issue requiring determination of the interrelationships of powers and limitations, see note 293 supra.

304. For the land area of Eniwetok, see N.Y. Times, Dec. 2, 1947, p. 24, col. 5.

305. N.Y. Times, Dec 25, 1947, p. 14, col. 3; id., Dec. 2, 1947, p. 24, col. 3. 
In the process of conducting the first test in history of a "high-yield" thermonuclear weapon, the force of the explosion was underestimated by half, and wind predictions, ordinarily highly accurate at sea, were erroneous. ${ }^{300}$ Minor injuries were suffered, in consequence, by the inhabitants of Rongelap Atoll, from which they have since recovered with no prospect of permanent after-effects. ${ }^{307}$ The United States has given assurances that all meritorious damage claims will be honored promptly. ${ }^{308}$ Neither fishing nor any other activities of the islanders were curtailed by the tests except in the case of the 236 persons evacuated temporarily from Rongelap and Utirik after the test of March 1st. ${ }^{309}$ United States Representative Sears informed the Trusteeship Council, on the basis of "security information," that there is "no chance of a recurrence" of the mishap that occurred in March 1954..$^{\text {310 }}$

For appraising reasonableness, it is material to note that if the United States had totally evacuated, in advance, every inhabited island affected by

306. N.Y. Times, April 1, 1954, p. 20, cols. 1-3.

307. See note 26 supra.

308. See note 7 supra.

309. Communication from Deputy High Commissioner, Trust Territory of the Pacific Islands, to the Yale Laze Journal, Feb. 24, 1955, on file in Yale Law Library.

The assertion in Margolis, p. 645, that the Marshallese were deprived of fishing: grounds for "months at a time," is true only of the 72 inhabitants of Rongelap, who were unable to fish for three months, after which they were resettled on Majuro Atoll. Communication from Deputy High Commissioner, supra. See also note 26 supra. Dr. Margolis' assertion that the tests have retarded "the development of fisheries" is misleading, since the Marshallese to date have engaged only in subsistence fishing, and the Administering Authority's efforts to develop commercial fisherics have not been successful. See the report of the visiting U.N. Mission to the Pacific Islands, U.N. Trusteeship Council Off. Rec., 12th Sess., Supp. No. 3, pp. 16-17 (Doc. No. $\mathrm{T} / 1077$ ) (1953), listing the virtually insuperable obstacles to development of a commercial fishing industry manned by the islanders. A principal difficulty, in the Visiting Mission's view, was that "the islanders are adjusted to a subsistence economy and lack the heritage and incentives to indulge in what is probably one of the most rigorous pursuits." Id. at 17.

310. U.N. Trusteeship Council OfF. Rec., 14th Sess., 561st meeting 245 (1954).

The assertions made by Margolis, pp. 639, $645 \mathrm{n} .86$, that the destructive power of nuclear weapons is "incalculable," and the injury to persons and property necessarily accompanies nuclear tests, are simply incorrect, if highest authority is to be believed. Sir Winston Churchill told the House of Commons, in April 1954, that "after full consultation with our technical experts," he could repeat the assurance previously given that there was "no foundation" for the suggestion that the explosions were "incalculable." N.Y. Times, April 6, 1954, p. 12, col. 3. See also Teller, The Work of Many People, 121 SCience 267, 270 (1955) ; Statement by Admiral Strauss in N.Y. Times, April 1, 1954, p. 20, col. 1. The Report of the AEC of February 15, 1955, makes clear that, in view of the vast distances separating inhabited islands in the Pacific, tests can be conducted with no danger of injury to anyone not participating in testing activities if certain simple precautions are taken. See note 35 supra. Had the fallout danger been known prior to the 1954 tests, most if not all injuries could have been avoided by the most elementary precautions. See Standing Committee on Petitions, U.N. Trusteeship Council, Summary Record 5 (Doc. No. T/C.2/SR. 197) (1954). 
the March 1st explosion and its fallout, 236 people and a total land area of 4.01 square miles would have been affected. ${ }^{311}$ In order to put these figures in perspective, it might be noted that if the United States had constructed a large airfield on one of the more heavily populated islands, its action would have affected more people and more land for a longer time, although such action would be within the terms of the Charter and the Agreement under any conceivable interpretation. It seems clear that unless an imaginative view of the facts is taken, the United States has not taken, and is never likely to need, an amount of land in the territory for weapons testing purposes which could be considered disproportionate or unreasonable.

The duties to promote the welfare of the inhabitants of the Trust Territory assumed by the United States in the Charter and Trusteeship Agreement, including the duty to protect the inhabitants' land and resources, appear to have been performed in an exemplary manner. The specific target of the provision in the agreement relating to land was the colonial practice, widespread before the war, of economic exploitation of the natives' land for the benefit of outsiders, relegating the indigenous population to the status of laborers or tenants. $^{312}$ In 1939, the population of the islands was 113,562 of which 73,028 were Japanese, and well over half the land in the islands was owned by the latter. ${ }^{313}$ By 1948 all the former Japanese residents had been repatriated to Japan, and the Administration had forbidden and still forbids acquisition of title to land in the territory by non-indigenous persons. ${ }^{314}$ Moreover, all land taken for public purposes has been replaced from the public domain. ${ }^{310}$ The extent to which the United States has carried out its duty to protect the health of the inhabitants may be seen in the fact that the indigenous population increased by nearly one-fourth in the first five years of United States administration, although it had decreased by one-fourth from 1935 to 1939,310 and in 1946 was reported "well on the way to extinction through disease." 317 Comparable progress in trade, conservation, agriculture, industry, transport and

311. See note 35 stipra.

312. This legislative intention is inferred from the contest in which the provision appears, and from the legislative history of Article 76 of the Charter. See Doc. No. 1090, II/4/43, 10 U.N. Conf. INT'L ORg. Docs. 563-64 (1945) ; cf. United Nations, Spechi Study on Econonic Conditions and Developarents 270-71 (U.N. Pub. Sales No. 1952, VI.B.2) (listing the principal land problems in non-self-governing territories).

313. Encyclopaedia Britannica World Atlas 225 (1942); U.S. Natr Dep't, Trust TERRITORY OF THE PACIFIC IsLANDS 30-32 (1948).

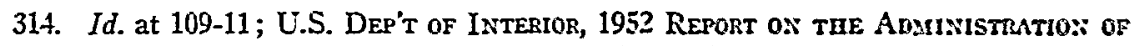
the Trust Territory of the Pactfic Islands 35 (1953).

315. Ibid.

316. Excyclopaedia Britannica World Atlas 225 (1942) ; and compare U.S. Nam DEP'T, op. cit. supra note 313, at 76, with U.S. DEP'T OF INTERIOR, op. cil. supra note 314, at 67 .

317. Statement by Rear Admiral C.A. Pownall, first post-war High Commissioner, in N.Y. Times, Feb. 20, 1946, p. 10, col. 5. 
communications, human rights, education, and standard of living is recounted in the Administering Authority's annual reports to the Trusteeship Council. ${ }^{\text {J18 }}$

The United States has repeatedly expressed its extreme regret that ill effects were suffered by the inhabitants of Rongelap as a consequence of its tests, and has promised both that it would give prompt and sympathetic attention to any claims for damage suffered in the past, and that nothing would be left undone to safeguard the present and future well-being of the inhabitants. $^{310}$ The Marshallese, acting through the authors of their petition to the Trusteeship Council, have expressed appreciation for the spirit in which the United States Government received their petition, and stressed that the petition should not be interpreted as a sign of lack of confidence in the United States as Administering Authority. ${ }^{320}$ On July 15, 1954, the United Nations Trusteeship Council, before which the conduct of the United States had been drawn in question, accepted by nine votes to three a resolution vindicating the United States and recommending that:

"if the Administering Authority considers it necessary in the interests of world peace and security to conduct further nuclear experiments in the Territory, it take such precautions as will ensure that no inhabitants of the Territory are again endangered, including those precautionary measures requested by the petitioners." 321

318. Reports for 1947-1950 were published by the Navy Department; later reports by the Department of the Interior. See also the favorable report of the U.N. Trusteeship Council Visiting Mission, supra note 309, passim.

319. See notes 6,8 supra.

320. U.N. Trusteeship Council OfF. Rec., 14th Sess., 561 st meeting 247 (1954).

321. U.N. Dóc. No. T/L.504, p. 2 (1954).

In view of the conclusion reached as to the legality of U.S. thermonuclear weapons tests in the Marshalls, brief mention of the proposals that the tests be conducted elsewhere should suffice.

Various commentators have urged that all tests be conducted henceforth within the United States. See, e.g., Margolis, pp.646-47; Arnold, Effects of the Recent Bomb Tests ont Human Beings, 10 BulL. Atons. Scientists 347, 348 (1954). The warning zone found necessary for conducting the 1954 Castle Series of tests in the Pacific was 400,000 square miles, equal to about one-seventh of the land area of the United States. While the danger of spreading radioactivity by ocean currents would be small or non-existent, so that a smaller danger area would no doubt suffice for tests conducted within the United States, evacuation of an area even remotely comparable to the Pacific zone would displace many thousands, and conceivably millions of people, and would radioactivate at least tcmporarily a vast area of useful land. Cf. Arnold, supra, at 348, making the incredible assertion that conducting tests in the U.S. would save money! It is reasonably obvious that the possible conscquences of tests in the U.S. cannot seriously be compared with test consequences in the Marshalls. See note 35 supra. The area covered by the Trust Territory and that of the United States are both approximately 3,000,000 square miles, but the Territory comprises only 846 square miles of land, of which islands totalling 166 square miles are uninhabited. Sce text at note 13 supra; U.S. DEP'T OF INTERIOR, 1951 REPORT ON THE ADMINISTRATION OF TIIE Trust Territory of the Pacific Islands 68 (1953). The total population of the entire Territory is 57,037 , ibid., approximately one-fourth that of Honolulu.

The authors do not profess to be qualified to say whether tests would be teclunically feasible in Alaska or the Arctic. However, these proposals by Margolis, pp. 646-47, raise 


\section{For A Free World and Free Seas}

The prospect of the possible use of the hydrogen bomb against human beings is almost too horrible to contemplate. It appears probable that each half of the world will shortly have the capacity quickly to destroy the other: the common analogy of two death-dealing scorpions enclosed in a small bottle has become all too apt. Under these circumstances the need for the peoples of the world to agree upon and enforce workable plans for disarmament and world public order could not be more urgent. We bow to none in recognition of this need and in demand for rational response. We do not, however, regard it as rational response for the free world unilaterally to disarm itself by the unnecessary extrapolation of broad prescriptions from the customary international law of the sea, created for other purposes, or by the narrow and technical interpretation apart from context of selected phrases from great international charters. ${ }^{322}$ Until a reasonably secure world public order can be established, the free half of the world has no alternative but to make certain that it remains a scorpion and does not invite transformation into inanimate radioactive dust. It is only by maintaining their capacity to defend their free institutions that proponents of human dignity can hope to achieve by peace-

interesting questions with respect to his arguments derived from the U.N. Charter and the "freedom of the seas" principle. Alaska is a "Non-Self-Governing Territory" to which Article 73 applies, Yeareoor of The United Nations 1948-1949, at 729-30 (U.N. Pub. Sales No. 1950,1.11), and the regime of the high seas applies at the least to unfrozen areas of the Arctic. Franklin \& MIcClintock, The Territorial Claims of Nations in the Aratie, 5 Onfa. L. Rev. 37, 43-44 (1952). It thus appears to be Margolis' position that tests in these areas would be more reasonable than tests elsewhere.

The facts suggest a different answer. Even if tests in Alasha and the Arctic are technically feasible, these areas are subjected to extremely erratic high winds, see, generally, Canada Dep't of Transport, Metrorology of the Canadiax Arctic 12-15, $53-55$ (1944), which could create intolerable danger for those conducting the tests, and might spread the effects of the fallout over vast distances. Moreover, accessible parts of both Alashia and the Arctic are closer to better fisheries, more heavily traveled navigational routes, and more heavily populated areas. Indeed, Alaska is closer to the mainland of Japan than is Bikini. Margolis is, finally, in error in asserting that the United States has laid claim to an arctic "sector." The United States is most persistent among the many states which unqualifiedly reject the validity of the "sector" theory. See U.S. NAML WAR CoLLEge, InTERNATIONAL LAW Docuarents 1948-1949, at 243-44 (1950).

In sum, there seems no reason to doubt the assertion of the United States that the Marshall Islands "were selected only because there is no other place in the world over which the United States has jurisdiction where ... [these] experiments could be suceessfully conducted with less danger." Mason E. Sears, U.S. Mission to the United Nations Press Release No. 1937, July 13, 1954.

322. World order does indeed depend upon "law," see IIargolis, p. 646, but law has little relation to the suicidal invocation and extrapolation of irrelevant, absolutistic labels. The proponents of human dignity face enough difficulties in their struggle for survival without inflicting unnecessary psychological wounds upon themselves. The prestige of the United States that matters depends, as does that of other bodies politic, not upon subservience to such labels, but rather upon the intensity of its dedication to the goal values of human dignity and its clarifying and adhering to an international law which rationally promotes such goal values. 
ful procedures a world public order which can continue to maintain that defense. Without at least a portion of the world defended in its freedom it would be folly to talk of freedom of the seas and the welfare of dependent peoples, both impossible to isolate from the freedom and welfare of a whole interdependent free world. The only rational policy for proponents of human dignity today is to demand, and to demand from a strength which insures respect, not merely spurious or naive legalisms and not merely freedom for navigation and fishing and the narrowly conceived and unrealistically isolated welfare of a few scattered peoples, but workable prescriptions and institutions for global disarmament and a world public order which will afford opportunity for the increasing freedom and welfare of all peoples in the full exploitation of all the world's riches. 


\section{THE YALE LAW JOURNAL}

\begin{tabular}{lll}
\hline VoluMe 64 & APRIL, 1955 & Number 5 \\
\hline
\end{tabular}

BARRY R. BRYAN Article and Book Review Editor

Irving J. Alter Peter W. ANson ROBERT W. BEREAND Danier M. Berger MIURRY D. BROCHIN Thontas N. Carruthers, JR. Donald J. Conn John W. Colleran Alan P. Colodny EDMund V. Conway Gerald M. Doppeit S. Gordon ElKINS JOEL M. FEINBERG JoSEPH M. FIELD BarRy M. Garfinkel Charles S. Hatget, Jr.

\section{EDITORIAL BOARD}

Jerosie A. Cohen Editor-iin-Chief

\author{
Willazar H. Dearpsey, Jr. Gernlo Walpin \\ Thoxras F. Nelson Managing Edilor \\ Gordon B. SpIVACK \\ Note and Comment Editors
}

Robert J. Harris Stepmen J. PoLtak

George C. Hastings Marmin N. Runas

Ira Mitchael Heyaran Bernard S. Rombris

Alexander P. Hoffarann Norbert A. SchleI

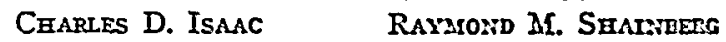

David B. Isbell Walter E. Shutraewortr

Lawrence R. Kletn Jeanne Ritchie Suver

Noel Arnold Levin Monroe Suverscins

Charles S. Miecheas, Jr. Robers J. Sise

Ralph C. Menarace, Jr. Arlen Specter

Edward A. Mimler Miectin Stem

JoN O. Newasan JoHN SUbah

Lawrence Newarai Charles H. Vejtoda

Martin Oppenmeizira Roger A. Welch

Otis P. Pearsall Howard P. Willesis

Richard H. Pershan George C. Zachary

marie McMiazon

Business Secretory

\section{CONTRIBUTORS TO THIS ISSUE}

Emanuel Margouss. B.A. 1947, University of North Carulina; Ph.D. 1951, Harvard University ; Instructor in Government \& International Relations, University of Connecticut, 1951-53; Member, American Society of International Law; American Political Science Association.

MYres S. MICDougal. B.C.L. 1930, Oxford University; J.S.D. 1931, Yale University: L.H.D. 1954, Columbia University. Member, Board of Editors, Amenren: Jounsial of International Law, Axtertcan Joursal of Comparative Law. William $\mathrm{K}$. Tounsend Professor of Law, Yale Law School.

Norbert A. Schler. B.A. 1950, Ohio State University. Afember, Editorial Board, Yale Law Journal. Lieutenant (j.g.), United States Naval Reserves. 